\title{
On Educating Children: A Parentalist Manifesto
}

\author{
Stephen G. Gilles†
}

In a liberal society, who should decide which values children are taught to live by? Many contemporary political and constitutional theorists answer this question by subordinating the authority of individual parents to overriding conceptions of liberal democratic values or to the decisions of political majorities. ${ }^{1}$ Other theorists seek to give the child primary responsibility for developing his or her own values by requiring both parents and the state to expose children to diverse values and beliefs. ${ }^{2}$ For its part, the Supreme Court has adhered to its Lochner-era pronouncement in Pierce $v$ Society of Sisters that parents have a constitutional right to direct and control the education of their children. ${ }^{3}$ But the Court has never developed a theory to explain this result. Nor has it clarified the terms on which this right coexists with what the Court has also declared to be the state's fundamental interest in ensuring that children are educated to be productive individuals and responsible citizens. ${ }^{4}$ Consequent-

$\dagger$ Professor of Law, Quinnipiac College. I thank Stephen Arons, Brian Bix, David Currie, Neal Devins, Laurie Feldman, Abner Greene, Richard Levy, Greg Loken, Nelson Lund, Michael McConnell, Sandy Meiklejohn, Linda Meyer, Lawrence Mitchell, Frederick Sperling, William Stuntz, Cass Sunstein, and participants in workshops at Fordham, Georgetown, Rutgers-Camden, and Quinnipiac for comments on previous drafts.

1 See generally Brian Crittenden, Parents, the State and the Right to Educate (Melbourne 1988); Amy Gutmann, Democratic Education 1-70 (Princeton 1987); Amy Gutmann, Civic Education and Social Diversity, 105 Ethics 557 (1995); Stephen Macedo, Liberal Civic Education and Religious Fundamentalism: The Case of God v. John Rawls?, 105 Ethics 468 (1995); Suzanna Sherry, Responsible Republicanism: Educating for Citizenship, 62 U Chi L Rev 131 (1995).

2 See generally Bruce A. Ackerman, Social Justice in the Liberal State 139-67 (Yale 1980); Patricia White, Beyond domination: An essay in the political philosophy of education 81-118 (Routledge 1983); John Holt, Escape from Childhood 240-48, 277-86 (Dutton 1974).

3268 US 510, 534-35 (1925) (invalidating Oregon law requiring students to attend public schools). See also Meyer v Nebraska, 262 US 390, 399-400 (1923) (striking down Nebraska law prohibiting schools from teaching languages other than English on the ground that it infringed on parental due process right to control children's education); Farrington $v$ Tokushige, 273 US 284, 298-99 (1927) (invalidating invasive Hawaiian regulation of "foreign language schools" on similar grounds).

- See, for example, Wisconsin v Yoder, 406 US 205, 213-14 (1972) (“Providing public 
ly, parental educational rights are both ill defined and vulnerable to unduly deferential judicial review of state educational regulation.

From the standpoint of parental educational authority, the dominant theories of liberal education, if translated into law, would make matters considerably worse. For example, Amy Gutmann's influential Democratic Education argues that every child must, as a matter of liberal political theory, receive an education that develops the child's capacity to engage in critical deliberation among competing conceptions of the good. ${ }^{5}$ Whereas current Supreme Court jurisprudence would allow parents to escape this contestable, value-laden conception of autonomy by paying to send their children to private schools, ${ }^{6}$ Gutmann would remove that exit option by requiring even private schools to teach her version of democratic values. ${ }^{7}$ Indeed, she would compel the states to implement her core prescriptions even if political majorities found them unacceptable. ${ }^{8}$

In this Article, I elaborate and defend a broader conception of parental educational authority. There are compelling reasons to give parents not only the right to transmit their values to their children, but also the right to reject schooling that promotes values contrary to their own. The first reason is one to which contemporary political theory has, at least in the abstract, proven quite receptive: that liberal societies characteristically renounce the use of coercive state power to impose even reasonable conceptions of the good life on persons who adhere to other-but likewise reasonable - conceptions. As John Rawls formulates this principle, "reasonable persons see that the burdens of judgment set limits on what can be reasonably justified to others, and so they endorse some form of liberty of conscience and freedom of thought. It is unreasonable for us to use political power... to

schools ranks at the very apex of the function of a State."); Ambach $v$ Norwick, 441 US 68, $76-77$ (1979) (observing that "the importance of public schools in the preparation of individuals for participation as citizens ... long has been recognized"); Bethel School District No 403 v Fraser, 478 US 675, 681-83 (1986) (describing one objective of education as "the inculcat[ion of] fundamental values necessary to the maintenance of a democratic system") (alteration in original); Brown $v$ Board of Education, 347 US 483, 493 (1954) ("Today, education is perhaps the most important function of state and local governments. ... It is the very foundation of good citizenship.").

- Gutmann, Democratic Education at 44 (cited in note 1).

- See, for example, Pierce, 268 US at 535.

7 Gutmann, Democratic Education at 115-23 (cited in note 1).

8 Id at 95-97. 
repress comprehensive views that are not unreasonable." ${ }^{n}$ On this understanding, the state acts illegitimately when it promotes some reasonable conceptions of the good at the expense of others by mandating the values children must be taught in school.

Many liberal people, however, accept toleration as a principle while rejecting (or sharply qualifying) its application to the education of children. Persons of this persuasion grant that the state may not force parents to conform their way of life to its preferred conception of the good. But children, they argue, should be treated differently, both because adult guidance and control is in their own best interest, and because the health and survival of the liberal polity depends on their becoming responsible citizens. Surely, the argument goes, the liberal state's manifest interests in protecting and promoting the best interests of children and the future civic needs of society itself are of greater moment than the interests of individual parents in directing the upbringing of their own children. Consequently, the state can legitimately claim far greater power to induce children to accept the majority's values than it can to induce their parents to do the same. ${ }^{10}$ In the realm of formal education, the government should have broad leeway to treat certain values as essential and others as unreasonable, and to enforce these judgments through coercive regulation.

To the contrary, I submit that the deference we extend to parental educational choices should approach (though not necessarily equal) the deference we give to the self-regarding choices of adult individuals. In education, as elsewhere, a comprehensive view should be seen as reasonable unless it rejects basic moral or liberal-political norms on which there is a general consensus among reasonable people in our society. ${ }^{11}$ At a minimum, we should treat as reasonable any comprehensive view that acknowledges the importance of normal human development, embraces civic toleration and respect for law, and acquiesces in our basic constitutional arrangements. ${ }^{12}$ Because few parents in our soci-

9 John Rawls, Political Liberalism 61 (Columbia 1993).

${ }_{10}$ See Prince $v$ Massachusetts, 321 US 158, 168 (1944) ("The state's authority over children's activities is broader than over like actions of adults.").

11 See, for example, Rawls, Political Liberalism at 59 (cited in note 9) ("We avoid excluding doctrines as unreasonable without strong grounds based on clear aspects of the reasonable itself. Otherwise our account runs the danger of being arbitrary and exclusive.").

${ }_{12}$ I draw heavily here on formulations in William Galston, Liberal Purposes 251 (Cambridge 1991). 
ety will choose to educate their children in ways that fail to satisfy these standards, states will only rarely be able to justify overriding parents' educational authority.

To make the case for using these highly pluralistic criteria for reasonableness, I appeal in part to our considered intuitions about toleration, diversity, and the minimum educational levels necessary for the maintenance of a liberal public order. ${ }^{13}$ The basic argument is that, except in the most extreme cases, liberal society can safely realize its legitimate educational interests without coercive interference with parental choices, and that pluralism therefore obliges society to rely on persuasive means to achieve its educational aims. But rather than rest the parentalist case exclusively on the liberal commitment to pluralism and toleration, I develop two further arguments that challenge the underpinnings of the conventional view that the state's claim to choose educational values for children has priority over the claims of their own parents.

First, the argument from parental incentives asserts that the state should defer to parents' educational decisions on the ground that parents are more likely to pursue the child's best interest as they define it than is the state to pursue the child's best interest as the state defines it. So long as both parents and the state define the child's best interest in terms of a reasonable conception of the good, we have no reason to prefer one definition over the other. The decisive question, therefore, should be which educational decision maker will more faithfully act in accord with its definition of the child's best interest. I argue that parents have better incentives to act in their children's perceived best interests than do the state and its delegates, and will consequently be, on average, more faithful educational guardians. We should therefore vest educational authority in parents rather than the state.

Second, the argument from parental ideals rejects the claim that the state has a paramount interest in controlling the education of its future citizens, on the ground that individuals have an even more fundamental interest in nurturing their children and in being nurtured by their parents. Contemporary liberal theory tends to assume not only that citizenship comes first, and individuality second, but also that-even within the realm of individuality-marriage, family, and child rearing are merely one prominent set of pursuits. These assumptions invert the priori-

${ }^{13}$ See Section III.A. See also Galston, Liberal Purposes chs $11-12$ (cited in note 12); William Galston, Two Concepts of Liberalism, 105 Ethics 516, 527-31 (1995). 
ties by which most reasonable people live. For the overwhelming majority, the loving relationships we share with our spouses, our children, our siblings, and the parents who educated us are at the heart of our individual conceptions of the good life. ${ }^{14}$ The project of educating our children, and of coming to know and love them in the process, is thus a defining feature of our life plans, not merely one preference among many. By the same token, children have a vital interest in being nurtured and educated by their parents. Parents' loving efforts to transmit their values help form their children's characters, enable them to learn what it is to have a coherent way of life, and develop their capacity to enter into caring, long-term relationships with others. In this sense, we might think of parenting as the familial reproduction, not of biological organisms or clones, but of sociable individuals. ${ }^{15}$

Now, liberalism rightly prides itself on its superior ability to satisfy both basic human needs and high human aspirations. A society that truncates parental educational authority in the name of publicly imposed educational norms falls short on both counts. The educational, reproductive labor of men and women-especially women - on behalf of their children will remain undervalued until liberal theory acknowledges both that children need value-laden, loving, parental educations, and that in providing for those needs parents express their deepest ideals and commitments. Liberal statecraft should not merely tolerate parental education: it should encourage and rely on that self-sacrificing, self-fulfilling work by respecting parents' educational choices unless they unreasonably deprive children of the essential prerequisites for adult life and liberal citizenship.

For all these reasons, the project of developing a mandatory democratic education for every child is profoundly misconceived. We cannot translate the general ideals on which there is an abstract liberal consensus-for example, civic toleration and lawabidingness-into concrete, legally enforceable educational requirements without outrunning and undermining that consensus.

14 Of course, for some persons the sphere of private family life may focus on other long-term affective relationships with friends or lovers. I in no way suggest that human lives are defective or unworthy absent marriage and children. My point is simply that long-term loving relationships constitute the main sphere of individual happiness for virtually everyone, and that marriage and child rearing are central to how most persons define that sphere in their own lives.

15 This formulation is intended to contrast with Gutmann's depiction of "conscious social reproduction" as the core liberal commitment underlying and justifying her mandatory, value-laden scheme of democratic education. See Gutmann, Democratic Education at 39 (cited in note 1 ). 
Hence the better course is to allow parents to choose how, and as part of what larger scheme of values, their children should be taught to be tolerant and law-abiding. The same point holds for the other virtues and values on which our public culture has come to a consensus, but which reasonable persons conceive of in quite different ways. In this respect, at least, our existing educational practices generally coincide with the conception of parental educational rights I propose. States prescribe certain subjects, but they ordinarily refrain from dictating the viewpoint and values that inform the teaching of those subjects in the private schools to which, under Pierce, parents must be allowed to send their children.

Nevertheless, current constitutional law both offers too little protection against the prospect that these practices will shift over time, and allows other forms of coercive pressure on dissenting parents to go unchecked. Under Wisconsin $v$ Yoder, ${ }^{16}$ parents are free to control the "religious upbringing" of their children-free, that is, to try to instill in their children their own religious beliefs. But because only parental values "rooted in religious belief" are eligible for free exercise protection, ${ }^{17}$ parents whose educational choices rest on moral or philosophical values are protected only by the Pierce reasonableness standard. That standard is problematic in at least two respects. First, it is often interpreted to mean that states need only show that their educational regulatory measures are "reasonable" in the sense that they bear some reasonable relationship to the state's general interests in enhancing children's educational opportunities and producing good citizens. Second, Pierce has been read to allow the practice of "selective funding,"18 in which only public schools receive direct, tax-financed educational subsidies. ${ }^{19}$ Selective funding exerts powerful-and highly questionable-financial pressure on dissenting parents to conform their educational choices to the majority's values by enrolling their children in public schools to avoid the heavy burden of private school tuition.

16406 US 205, 233-35 (1972).

17 Id at 215-16.

18 The phrase is Michael McConnell's; it applies to any situation in which government selectively funds one private choice or activity (for example, childbirth) while refusing to fund close substitutes or alternatives (for example, abortion). See Michael McConnell, The Selective Funding Problem: Abortions and Religious Schools, 104 Harv L Rev 989, 989 (1991).

19 See, for example, Mark A. Yudof, When Government Speaks: Politics, Law, and Government Expression in America 230 (California 1983) ("The state must tolerate private education, but. need not fund it."). 
This Article maps out the issues, develops the core arguments on which a robust conception of parental educational authority rests, and critiques the contrary views of theorists such as Bruce Ackerman, Brian Crittenden, Amy Gutmann, Stephen Macedo, and (to a lesser extent, for our views are closer) William Galston. The piece is meant, however, to provide an exploratory treatment rather than a completely worked-out theory. This is particularly true with regard to the delicate business of determining how (if at all) the theory's conclusions translate into doctrines of federal constitutional law. My principal aim is to show why parental educational rights ought to receive constitutional protection; it is not to establish that our existing Constitution, rightly interpreted, in fact creates such rights. Powerful criticisms have been lodged against the entire enterprise of substantive due process ${ }^{20}$ and also against the application of portions of the Bill of Rights to the states via "incorporation" into the Due Process Clause of the Fourteenth Amendment. ${ }^{21}$ If those criticisms are right, then none of the salient federal constitutional vehicles for parental educational rights-the Due Process Clauses, the Free Exercise Clause, and the Free Speech Clause - constrains the states. ${ }^{22}$ It may simply be that parental educational rights have convincing support in liberal political theory but not in the federal Constitution. ${ }^{23}$

${ }^{20}$ See, for example, David P. Currie, The Constitution in the Supreme Court: The Second Century, 1888-1986 47-50, 466-67 (Chicago 1990); David P. Currie, The Constitution in the Supreme Court: The First Hundred Years, 1789-1888 271-72 (Chicago 1985).

${ }^{21}$ See, for example, Raoul Berger, The Fourteenth Amendment and the Bill of Rights (Oklahoma 1989); Currie, The Second Century at 155 (cited in note 20); Currie, The First Hundred Years at 345-47, 366-68 (cited in note 20); William E. Nelson, The Fourteenth Amendment: From Political Principle to Judicial Doctrine 117-19 (Harvard 1988). There is also much historical scholarship to the contrary. See, for example, Akhil Amar, The Bill of Rights and the Fourteenth Amendment, 101 Yale L J 1193 (1992) (proposing a "refined incorporation" of the Bill of Rights by examining the degree to which a right pertains to individuals or to the states); Earl M. Maltz, Civil Rights, the Constitution, and Congress, 1863-1869 113-18 (Kansas 1990) (arguing from original intent for limiting the scope of the Fourteenth Amendment). In addition, of course, there is the question whether pragmatic or other nontextualist grounds might justify incorporation even if the doctrine falls outside the original meaning of the Fourteenth Amendment. See, for example, Richard A. Posner, Bork and Beethoven, 42 Stan L Rev 1365, 1373-74 (1990).

22 In that event, the possibility that the Equal Protection Clause provides significant protection against state interference with parental educational authority would loom much larger than it does now.

${ }^{23}$ Many state constitutions contain provisions protecting the freedoms of speech and religion; these would, of course, retain their force. See, for example, Va Const, Art I, $\S \S 12$, 16; Del Const, Art I, §§ 1, 5. This Article does not address these potentially important sources of protection for parental educational authority. 
On the other hand, the Supreme Court has remained unpersuaded by these criticisms, and substantive due process and selective incorporation thus appear to be permanent features of constitutional law. Accordingly, I examine how the theoretical arguments for broad parental educational authority might play out within the doctrinal frameworks of substantive due process, free exercise, and free speech. In each instance, parentalist theory illuminates the existing precedents in ways that suggest a more protective conception of parental educational rights. For example, building on the Supreme Court's explication of substantive due process in Planned Parenthood $v$ Casey, ${ }^{24} \mathrm{I}$ argue that the Pierce reasonableness standard should be interpreted to require states to show that the parental educational choices with which they would coercively interfere are plainly unreasonable. ${ }^{25}$

Finally, I offer an alternative proposal for reestablishing parental educational rights on what I see as the firmer constitutional foundation of the First Amendment. If Pierce and Meyer $v$ Nebraska $a^{26}$ arose today, they might best be viewed as cases involving the free speech rights of parents. Because parents educate their children by communicating with them, the free speech case for parental educational rights is surprisingly strong. Parents' educational messages to their children, whether delivered directly by parents in the home or indirectly through their agents in the school, should be treated as parental educative speech, and should receive a high level of First Amendment protection similar to that currently afforded to political speech. ${ }^{27}$ This paradigm would place the focus of the constitutional inquiry where it may best belong: on whether state educational action interferes on the basis of content or viewpoint with parents' efforts to communicate their values and beliefs to their children.

24505 US 833 (1992).

${ }^{25}$ This standard looks primarily to the child's best interest, but it also enables courts to consider society's legitimate interest in the child's future behavior as an adult citizen.

${ }^{26} 262$ US 390 (1923).

27 This proposal is indebted to, but departs significantly from, Stephen Arons's account of First Amendment educational rights in Compelling Belief: The Culture of American Schooling 189-221 (Massachusetts 1983) (arguing that the First Amendment protects the child's right to form his or her own beliefs free from state educational indoctrination, and that parents of young children may invoke this right on their children's behalf). See also Stephen Arons, Six Cases In Search of a Theory: Government Regulation of Nongovernment Schools, 1 Threefold Rev 8 (1989); Stephen Arons, The Separation of School and State: Pierce Reconsidered, 46 Harv Educ Rev 76 (1976); Stephen Arons and Charles Lawrence III, The Manipulation of Consciousness: A First Amendment Critique of Schooling, 15 Harv CR-CL L Rev 309 (1980). 


\section{The Case For Parental Educational Authority}

In this Section, I develop the argument for broad parental educational authority as a matter of liberal political and constitutional theory. Section I.A explains why limiting and distributing educational authority over children are difficult issues for a liberal society. Section I.B then critiques Bruce Ackerman's claim that neither parents nor the liberal state should be allowed to educate children in accord with a particular conception of the good life. Liberal states may, and should, impose important limits on the duration, intensity, and extent of educators' authority over children-whether the educators are parents, parentally chosen teachers, or the public schools. But those limits do not include a requirement that every child's education be relentlessly neutral in exposing the child to a wide range of competing ways of life.

Sections I.C and I.D present the affirmative case for the proposition that individual parents (rather than the state or its agents) should decide what values their child will be taught at home and at school. The argument from parental incentives ${ }^{28}$ offers a neutral reason-namely, their superior incentives-to prefer parents' evaluation of their child's best interest to the state's. The argument from parental ideals ${ }^{29}$ explains why the human flourishing of both parents and children depends on parental nurturing and education, and why parental control over the values children are taught is essential to that enterprise. Neither argument, of course, denies that parental educational authority is both limited by the norms against cruelty and coercion, and subject to affirmative educational obligations to the child-such as basic literacy, numeracy, and what William Galston calls "normal development." These limits and obligations, however, must not be transformed into means for countermanding parental educational value choices that fall within the very wide range of comprehensive views that members of a pluralist society must tolerate as reasonable. The overarching standard should be that parental educational choices are to be free from coercive state interference, direct or indirect, unless there is consensus that those choices are unreasonable in terms of basic human needs or essential liberal competencies. ${ }^{31} \mathrm{We}$

30 Galston, Liberal Purposes at 252 (cited in note 12).

31 Even as to unreasonable parental choices, the better course may sometimes be to rely on persuasion rather than coercion; that prudential judgment, however, may legiti- 
ought therefore to recognize, as a matter of liberal constitutional theory, that parents' educational rights include the authority to reject state educational requirements that subvert or clash with the values they are trying to instill in their children.

\section{A. The Problem of Educational Authority}

Liberal societies are committed to treating adults as selfgoverning persons entitled to choose and pursue their own conceptions of the good life..$^{32}$ Liberal constitutions therefore refrain from requiring citizens to conform to any one conception of the good life, and prohibit political majorities from using state power for that purpose absent some overriding justification. ${ }^{33}$ The same goal-ensuring the liberty of individuals-requires the state to protect its citizens from the abuses of private power. Consequently, no one in a liberal society may coerce another's choice of values or beliefs unless somehow privileged to do so. The baseline for defining coercive behavior (or sufficient justifications) may shift as one moves from state action to private conduct, but the core principle still holds: in a liberal society, all authority is limited, and all coercion requires reasoned justification. $^{34}$

These widely held principles provide an initial fix on the problem of liberal educational authority. The root difficulty is that human beings are not born into the world as self-governing, reasoning individuals. If they were, education might still be necessary, but it would not be problematic. By hypothesis these persons would, from birth, be capable of deciding for themselves what values and conception of the good life to adopt. Consequently, neither the liberal state nor their parents could legitimately assert the right to choose on their behalf.

mately be left to the discretion of the majority.

${ }_{32}$ See, for example, Rawls, Political Liberalism at 29-35 (cited in note 9); Galston, 105 Ethics at 527-28 (cited in note 13).

${ }^{33}$ Of course, these propositions are subject to many qualifications. For example, no one thinks it unjust to prevent a person from pursuing happiness by inflicting harm on others. Nonetheless, as the First Amendment's Religion Clauses illustrate, state action that promotes some faiths or ways of life at the expense of others stands in need of special, neutral justification. For an argument that the Religion Clauses commit American constitutionalism to a strong version of liberal pluralism, see Michael W. McConnell, Multiculturalism, Majoritarianism, and Educational Choice, 1991 U Chi Legal F 123, 13134.

34 I take this to be one of Bruce Ackerman's central theses in Social Justice (cited in note 2). See id at 4 ("No form of power is immune from the question of legitimacy."). 
Real newborns, however, are born weak, dependent, and unable to reason or govern themselves. The nurturing and education children need will inevitably and profoundly shape their initial values and beliefs. The authority to conduct and control childhood education thus carries with it the ability to determine what conception of the good life shall dominate children's formative years. The problem thus posed is how and on what principles a liberal constitutional order should allocate educational authority over children.

This problem has three distinct aspects. The first is how to limit educational authority so that educators cannot simply coerce children to adopt their preferred values or refuse to allow them independence when they become adults. The second is how to allocate educational authority between parents and the state. The third is whether, and to what extent, to resolve these issues at the constitutional level or leave them instead for majoritarian political resolution. In the following Section, I take up the first of these issues.

\section{B. The Limits of Educational Authority}

Most academic writing about education proceeds on the assumption that the combined authority of parents, schools, and the state over the child's education is quite extensive. Parents and teachers cannot abuse or imprison a child, but as educators they may decide what values to teach the child, even if the child resists or disagrees. On this view, the crucial question is how to apportion the broad grant of educational authority between parents and the state (with teachers as agents of one or the other). Those who argue that children should have greater rights to control their own education, however, reject the conventional view. ${ }^{35}$ Before turning to the issue of allocating educational authority, therefore, it is necessary to confront this challenge. In this Section, I do so by evaluating and rejecting one of the most sophisticated versions of the child's-rights argument, as advanced by Bruce Ackerman in Social Justice in the Liberal State. ${ }^{36}$

Liberal educational theory, as Ackerman develops it, would so radically curtail the authority of both parents and the state that issues of authority allocation would be relatively unimportant. ${ }^{37}$ In effect, Ackerman would constitutionalize a rule that 
every child must be exposed to a wide range of values and conceptions of the good, so that the child will be able to choose his or her own ideals as part of an ongoing process of "self-definition. ${ }^{38}$ For Ackerman, the main task of liberal education is to ensure that no one is able to inculcate in children "an uncritical acceptance of any conception of the good life."39 In his view, liberalism's commitment to the autonomy of adults entails a parallel commitment to the autonomy of children. ${ }^{40}$ Within practical limits, those who educate children should strive not to instill their values, in order that the child can begin to develop his or her own. Unless educational authority is so limited, the child's neediness becomes the pretext for overreaching by the educators. As future citizens of a liberal society, children's true need is to have their capacity for autonomous choice respected and enhanced at every stage, not to be subjected to majority or parental values. ${ }^{41}$

This claim about what human beings truly need obviously rests on a particular conception of autonomy, and more generally on a conception of the good life as one that is autonomously chosen in a certain way. Ackerman tries to make self-development an attribute that is compatible with a wide range of conceptions of the good. In his system, education will expose the child to the committed fundamentalist along with the committed evolutionist and the committed skeptic, and the child could conceivably adopt any of these views. ${ }^{42}$ Pluralist as this may seem, the reality is that Ackerman's education steers the child in a way that excludes quite as much as it includes. Any conception of the good that requires greater educational guidance than Ackerman allows is forbidden full play.

Many widespread conceptions of the good life are linked to educational aspirations and practices of just this kind. Believers in quite diverse ways of life (secular as well as religious) are

have custody of their children, and could express their own values, but would be required to send their children to a "liberal school" whose curriculum would "equip[] the child to question, as well as affirm, family values." Id at 156. Those in charge of these schools would be obliged to ensure that no one conception of the good dominated any child's curriculum. See id at 156-59.

38 Id at 154.

39 Id at 163 .

to Id at 139 .

41 See, for example, id at 162 ("[W]hat is required is a cultural environment in which the child may define his own ideals with a recognition of the full range of his moral freedom.").

12 See id at 159. 
alike in thinking that their children should be brought up to believe in their way of life, so that they will learn its full meaning and rewards, and thus adhere to it as adults. Ackerman treats acting on this sort of educational judgment as illiberal in principle. ${ }^{43}$ His brand of liberalism requires a commitment to the view that the child's freedom to choose must trump the values of the child's educators, whoever they prove to be. ${ }^{44}$

But why is such a commitment inherent in liberalism? Many people think a child gradually achieves true autonomy by making choices and acting well within a belief system that the child's parents adhere to and instruct the child to accept as true. ${ }^{45}$ Opinions of this stripe cannot be discredited merely by labeling them authoritarian. For it is central to the traditionalist conceptions of the good from which these opinions derive that unconditioned, undirected freedom to develop one's own values often leads children to choose bad and self-destructive values. Authority can thus reasonably be seen as practically necessary to achieving virtue and, with it, true autonomy.

Ackerman offers no convincing argument for regarding these conceptions of the good life (and of how children should be educated so that they will choose such lives) as unreasonable or inconsistent with liberalism. He rightly points out the moral hazard inherent in educational aspirations of this kind: that educators may impose their values on children to gratify their own desires for power and control rather than for the child's good. ${ }^{46}$ But he overlooks the parallel moral hazard under his scheme: that educators will abdicate their responsibility to direct the formation of the child's values in ways that do serve the

43 See id at 148 (announcing, in the context of justifying parental control over children, the "principle" that "authority over children is not justified by adult pretensions to moral superiority"). Gutmann provides an effective critique of this aspect of Ackerman's argument. See Gutmann, Democratic Education at 35-38 (cited in note 1).

4 Ackerman acknowledges that "parental control" over children is necessary to teach children "habits of self-discipline" that will enable them to "deal with [their] aggressions." Ackerman, Social Justice at 149 (cited in note 2). He claims, however, that the justification for this kind of parental control is solely to "increase the youth's capacity to remain free of the special restrictions imposed on aggressive adults by the criminal law." Id at 148. Parental control, therefore, implies for him no concession whatever to "adult pretentions to moral superiority." Id.

45 Here and throughout this Article, I rely on Alasdair MacIntyre's account of what it means to live, learn, and reason within a tradition, be it religious or philosophical. See Alasdair MacIntyre, After Virtue: a study in moral theory (Notre Dame 1981); Alasdair MacIntyre, Whose Justice? Which Rationality? (Notre Dame 1988).

t6 See Ackerman, Social Justice at 160 (cited in note 2) (describing voucher schools as "petty tyrannies in which like-minded parents club together to force-feed their children without restraint"). 
child's good. ${ }^{47}$ Indeed, ordinary experience suggests that many (if not most) children, if raised in accord with Ackerman's plan, would choose a life of easy, immediate, undisciplined self-gratification, rather than a life of responsibility, hard work, and selfdiscipline. ${ }^{48}$ Without these characteristics children are unlikely to satisfy their own long-run interests or to behave fairly and respectfully toward others. In short, Ackerman's education may foster persons who are slaves to their own appetites, rather than self-governing moral individuals.

Or so a reasonable person might think. The belief that children need to be raised in accordance with a single, coherent conception of the good seems, to use Ackerman's phrase, "at least as good $^{\prime 49}$ as the belief that education should systematically expose children to a variety of values and ways of life. Ackerman thus fails to establish that liberalism's commitment to adult autonomy requires drastic restrictions on educational authority over children. There is a liberal consensus that educators may not use brute force, starvation, or other starkly coercive means to enforce submission to their values, and that their authority must be limited in duration as well. ${ }^{50}$ Hard questions remain about just where these lines are to be drawn. But these limits leave educators with a range of means to induce and persuade children to adopt a conception of the good that is far wider than Ackerman would permit. ${ }^{51}$

That a liberal society may legitimately grant educators broad authority to instill values in children, of course, does not necessarily mean that it must do so. It might be possible to bypass this

47 He also overlooks the powerful countervailing incentives that operate in the case of parental educators who desire the good for their children and seek to instill in them the values the parents themselves live by. See Section I.C.

${ }^{13}$ Studies of human development tend to confirm this intuition. See, for example, Laura M. Purdy, In Their Best Interest? The Case Against Equal Rights for Children 113 (Cornell 1992). Purdy posits goals of "self control and certain enabling virtues based on that control, such as the appropriate use of reason, hard work, and tenaciousness in pursuit of excellence," and concludes that "the best available evidence suggests that letting children make all their own decisions from the earliest possible age does not contribute toward these goals." Id.

49 See Ackerman, Social Justice at 130 (cited in note 2).

so See, for example, id at 154-58.

${ }_{51}$ Ackerman does grant parents the "right to try to impress our children with the things that are most important to us." Id at 140. That right, however, is subordinated to parents" "obligation to refrain from using their residual authority in ways that sabotage the child's right to a liberal education" that "equips the child to question, as well as affirm, family values." Id at 156. Parents (and other educators) thus have a right to be heard, but only as one voice among many. 
issue on the grounds that the thrust of our educational practices (public and private) has always been to teach children to believe in certain values and to regulate their exposure to conflicting values. Present-day proposals to give children much greater control over their own education raise interesting theoretical questions, but have little chance of becoming law. ${ }^{52}$ As will become clear, however, the decisive arguments for parental educational authority also imply that the scope of that authority cannot legitimately be truncated in the ways Ackerman favors. Individual parents remain free to follow Ackerman's prescriptions, but the state may not coercively impose them.

\section{The Argument from Parental Incentives}

We can all agree that children need an education, and that this education must both be consistent with, and prepare them for, their future autonomy as adults. But the fact of ineradicable pluralism must be reckoned with. We cannot agree on the good life, and consequently we cannot agree on the good education. This deadlock makes the problem of allocating educational authority all the more urgent: what is at stake is who decides what kind of education the child shall receive. Yet if we cannot agree on the good education, how can we hope ever to agree on the good educator?

\section{The child's best interest as a neutral principle.}

The solution to this quandary derives from the familiar liberal proposition that educational authority must be justified primarily in terms of the child's best interest. ${ }^{53}$ Our disagreements about education and the good life mean, of course, that we will not always agree about what constitutes the child's best interest. But although our pluralism is ineradicable, it is not all-encom-

52 Ackerman includes such a proposal as one element of his liberal educational principles. Id at 158 ("As the child gains increasing familiarity with the range of cultural models open to him in a liberal society, the choice of his curriculum should increasingly become his responsibility, rather than that of his educators."). See also Holt, Escape from Childhood at 240-48 (cited in note 2) ("I want [young people] to have the right to decide if, when, how much, and by whom they want to be taught .....").

53 This is not to say that the only justification for educational authority lies in the child's interests. The human flourishing of adult parents, which is highly bound up with the education of their children, matters too, as does society's interest in good citizens. Nonetheless, no justification is persuasive if it fails to give great weight to the child's best interest. See John E. Coons and Stephen D. Sugarman, Education by Choice: The Case for Family Control 35-70 (California 1978). 
passing. Notwithstanding our inability to reach consensus on the good life in its entirety, we can agree on certain basic human goods (and bads). ${ }^{54} \mathrm{~A}$ basic education that equips the child to speak, read, write, calculate, and reason is, I shall assume, among the minimum human goods necessary for normal human flourishing in our society.

Now, if this modest assumption about the child's best interest is correct, we have converted an allocation issue into an affirmative limit (indeed, an obligation) on the child's educators-whoever they turn out to be. We have a consensus that every normal child's education should aim at equipping the child with these basic skills. That, in turn, gives us a benchmark with which every child's education must, in principle, comply. A law making that benchmark binding is therefore plainly legitimate.

In theory, it might be possible to push this strategy even further. Maybe, despite our pluralism, we could reach consensus on certain virtues and values that should form a part of every child's upbringing. Later in this Article, I explore some of the difficulties with such an enterprise. ${ }^{55}$ For now, however, the crucial points are (1) that even if such a consensus eventually emerged, it would be radically incomplete as a full guide to the good life, and (2) that persons holding a wide range of conceptions of the good life would recognize this incompleteness. In other words, on due reflection most thoughtful people would acknowledge that children need a more comprehensive, valueladen education than the "thickest" conception of education on which we can hope to reach consensus. ${ }^{56}$ Consequently, the pluralist educational quandary reappears in a narrower but seemingly intractable form: we think it is in the child's best interest to have a comprehensive education, but we recognize the impossibility of attaining consensus on what conception of the good shall inform that education. Here the fundamental choice is starkly posed: Shall we allocate this comprehensive educational authority (subject to the limits and obligations already noted) to individual parents or to democratic majorities?

The criterion with which we began-the child's best interest-supplies an answer to that question. We should allocate

54 For development of this point, see Galston, Liberal Purposes at 252-53 (cited in note 12).

ss See Section II.

${ }^{86}$ This formulation is meant to include Ackerman. His system of education promotes the comprehensive value of autonomous self-development-a value on which we cannot expect to reach consensus. 
comprehensive educational authority to whoever is most likely to act in the child's best interest. Within the realm of reasonable comprehensive views, we cannot say with confidence that the majority's conception of the good is more likely than the parents' conception to be in the child's best interest-or vice versa. But we can say with confidence that the child's parents are more likely to act in the child's best interest as they understand it than is the majority to act in the child's best interest as the majority understands it. ${ }^{57}$ Parents have better incentives to act as faithful agents on their child's behalf than does the majority (or those, such as teachers, to whom the majority might delegate its authority). ${ }^{58}$ If this claim is correct, we have a good-and neutral-reason to allocate educational authority to individual parents rather than to the liberal state.

\section{Parental incentives to act in the child's best interests.}

Evidence for the proposition that parents have powerful incentives to pursue their own child's best interest comes in a variety of forms. To begin with, there is the cumulative testimony of Locke and countless other observers that parents seem naturally inclined to love and care for their children. ${ }^{59}$ Contemporary economic analysis of the family says much the same thing in a different conceptual vocabulary: parents tend to identify their children's interests as an important part of their own interests. ${ }^{60}$ These generalizations, however, do not always hold: some parents neglect, abuse, or even kill their children. But that sad fact cannot be decisive in a culture in which most parents do care

57 Throughout this argument, I draw on the especially helpful analysis of an "educational best interest of the child" standard in Coons and Sugarman, Education by Choice at 35-70 (cited in note 53).

ss Of course, the majority might delegate its authority to individual parents. But the question we are concerned with is whether individual parents should have comprehensive educational authority even if the majority would deny it to them.

so John Locke, The Second Treatise on Civil Government $\$ \mathrm{XV}$, in Maurice Cranston, ed, Locke on Politics, Realism and Education 79-81 (Collier 1965); John Locke, Some Thoughts Concerning Education § II(1) in Maurice Cranston, ed, Locke on Politics, Realism and Education 157 (Collier 1965). See also Nathan Tarcov, Locke's Education for Liberty 68-69 (Chicago 1984). The nineteenth-century common law cases endorsing parental educational rights stressed parents' knowledge of their children and the "natural affections" inclining them to act in their children's best interests. See Mary-Michelle Upson Hirschoff, Parents and the Public School Curriculum: Is There A Right To Have One's Child Excused from Objectionable Instruction?, 50 S Cal L Rev 871, 888-89 (1977).

${ }^{60}$ See, for example, Richard A. Posner, Sex and Reason 189 (Harvard 1992) (discussing parental altruism). For economic analysis of parental investment in children, see Gary S. Becker, A Treatise on the Family chs 5-6 (Harvard 1991). 
deeply and well for their children, and in which abusive treatment of children by foster parents and other agents of the state is no less prevalent. ${ }^{61}$ We do not abandon the principle of adult self-governance just because many adults mistreat, abuse, or even kill themselves. Instead we selectively depart from that principle in particular cases, such as a mentally ill person whom we confine involuntarily on grounds of self-dangerousness.

We take the same basic approach to parental custody. Unless parents' treatment of their child violates widely shared norms of decency-unless, in other words, it is demonstrable that the parents are behaving unreasonably and in ways harmful to the child-we do not intervene. Rather than prescribing the best diet or the best style of parenting, we police the extremes. These practices attest to a broad societal consensus in favor of general parental control and custody of children, a consensus that rests in large part on the judgment that parents normally act in their children's best interests. ${ }^{62}$

The attributes of parental status in our society strengthen parents' natural incentives to care for their own offspring. Parents stand in a long-run relationship with their children: they are obliged to raise and support them until emancipation. This arrangement encourages parents to love their children, if for no other reason than that it is unpleasant to be legally encumbered with massive and continuing responsibilities for a person whom one dislikes.

Conversely, parents want their children to love them: this is one reward for a parent's investment in his or her children. But to love someone-in the sense of caring for that person-is to desire that person's human flourishing. Parents, as custodians who share a common life with their children, therefore have strong emotional incentives to act in their children's best interests. $^{63}$

61 See Parham v J.R., 442 US 584, 603 (1979) ("The statist notion that governmental power should supersede parental authority in all cases because some parents abuse and neglect children is repugnant to American tradition.") (emphasis deleted).

62 See, for example, id at 601-02 (arguing that the traditional "Western civilization concepts of the family as a unit with broad parental authority over minor children" are rooted in recognition that "natural bonds of affection lead parents to act in the best interests of their children.").

63 This part of the argument depends on the dynamics of a long-run custodial relationship with a child, rather than on natural affinity between children and their biological parents. Obviously, however, these two factors tend to reinforce each other in a society in which biological parents normally are also custodial parents. 
Parental incentives come in a variety of forms besides loving and desiring to be loved. Society blames parents for the misdeeds and shortcomings of their children, and praises them for their children's achievements. Parents whose children turn violent in adolescence may suffer physical harm or financial liability. Historically, and to a lesser extent still today, aging parents may need help and support from their adult children. Taken together, these incentives give parents powerful inducements to act in their child's best interest as the parents understand it in light of their conception of the good.

In the end, however, whether parents have strong incentives to act in their child's perceived best interest is not dispositive. Instead, the question is whether their incentives are better than those of the rival candidates for status as the child's educational guardian-not only the majority and its elected representatives, but also education officials, school teachers, guidance counselors, and others in whom the majority might vest educational authority over children. In making these comparisons, of course, liberal neutrality requires us to assume that neither parents nor the majority and its delegates have any superior capacity to discern the human good. Consequently, it is irrelevant whether we imagine parents whose conception of the good is the same as, or different from, that of the educational decision makers society might substitute for them. In either case, the ultimate issue is the same: Treating their respective conceptions of the good as equally valid, which would-be educator-the parents or society's substitute for them-is more likely to identify and act in the child's best interest, defined in terms of that educator's conception of the good?

\section{Parents' and teachers' incentives compared.}

Let us now compare parents' incentives with those of school teachers. To make the initial comparison as favorable to teachers as possible, suppose that schools are publicly funded but run by teachers or their elected leaders and that society has charged them with the responsibility for educating every child in his or her best interest as the teacher perceives it. Suppose further that all teachers teach, at least in part, because they enjoy working with children and value children's educational progress.

Even on these rather optimistic assumptions, is it not clear that teachers' incentives to act in the child's educational best interest are far weaker than those of individual parents? The teacher will spend a fraction of each school day with the child for 
perhaps a year. The teacher will have many pupils to care for, and in any event professional caring preserves a certain distance from the child. ${ }^{64}$ The teacher will have personal or family commitments of his or her own. Although teachers individually may assign intrinsic value to teaching, teachers collectively may structure school rules to reduce their workloads and responsibilities. Moreover, society cannot hold teachers accountable, either individually or collectively, in the ways that it can parents. As compared to parents, individual teachers bear far less of the costs associated with a badly educated child and far less of the benefits associated with a well educated one. Consequently, their incentives to act in the child's best educational interest are plainly inferior.

But what about teachers' educational expertise? Some contemporary observers would deny that teachers' professional training makes a significant contribution to their capacity for effective teaching. ${ }^{65}$ Rather than join in that debate, however, let us assume that many teachers bring significant expertise to educating children. ${ }^{66}$ All the more reason to follow the usual model of professionalism, which would place educational decision-making authority in the hands of the party with the best incentives to demand and make use of that expertise: the consumer, or in the case of child consumers, parents. ${ }^{67}$ Let parents choose teachers, and the demand for expert teachers will increase. ${ }^{68}$

Once we relax the unrealistic assumption that teachers will operate within a system that they control qua teachers, the comparative disadvantage of teachers as against parents dramatically increases. As John Chubb and Terry Moe have recently argued, the fact that public schools are democratically controlled entails large costs in terms of educational effectiveness. ${ }^{69}$ The list of rent seekers - education bureaucrats, teachers as an organized interest group, book publishers, and other suppli-

See Coons and Sugarman, Education by Choice at 57-58 (cited in note 53).

65 Rita Kramer, $E d$ school follies: the miseducation of American teachers (Free Press 1991) (reporting the inadequate training of American teachers).

${ }_{66}$ Even on this assumption, one might think that parents' greater knowledge of their child's individual aptitudes and needs more than offsets teachers' greater expertise.

${ }^{67}$ See Coons and Sugarman, Education by Choice at 59 (cited in note 53).

B Indeed, most parents understand that teachers are sometimes more effective instructors precisely because they are not the child's parents. This is hardly a sufficient reason, however, to compel parents to surrender their authority to decide what their children should be taught.

${ }^{69}$ John E. Chubb and Terry M. Moe, Politics, Markets, and America's Schools 2 (Brookings 1990). 
ers-goes on and on. None of these groups has as its raison d'être the best educational interests of children, and each of their interests sharply diverges from the interests of children in a variety of ways. As one would expect, therefore, our actual system of public education is in many respects structured to meet the demands of these well organized interest groups rather than the demands of parents or the needs of children. ${ }^{70}$ But at least in the current system parents are one major educational interest group, even if they are often not the best organized. What we are now imagining, however, is a system in which formal educational authority would be vested in public school authorities to the exclusion of parents. Such a system, even if premised on a global command that schools and teachers act in each child's educational best interest, would fall radically short of that goal in practice.

To be sure, this analysis presupposes teacher-student relationships as they are, rather than as they might be in a school system dedicated to children's best interests. As Coons and Sugarman note, the best alternative to parental educational control might be to give every child "a personal educational guardian who is to take an ongoing interest in his education."71 As they also point out, however, reform of this kind is tantamount to creating a new species of appointed "educational parent[s]." ${ }^{72}$ There is no reason to think that reinventing the wheel in this way would confer benefits commensurate with the obvious costs involved in selecting, training, and monitoring these specialized parental surrogates. Nature provides us with parents for children, and by regulating the parent-child relationship we can at low administrative cost enhance the natural incentives parents have to act in their child's best interest. Thus, parental educational authority yields better incentives at lower cost. Where incentives and administrative costs point in the same direction, we have what ought to be an easy case. ${ }^{73}$

${ }^{70}$ Id ch 2 (arguing that the influence of these interest groups undermines school autonomy, causing schools to fail to meet the needs of children and parents). See also Coons and Sugarman, Education by Choice at 57 (cited in note 53) (describing various bureaucratic and institutional features of public schools that are unjustified in terms of the child's interest).

71 Coons and Sugarman, Education by Choice at 61 (cited in note 53).

72 Id.

${ }^{73}$ See Richard A. Epstein, Simple Rules for a Complex World 34-35 (Harvard 1995). 
4. The incentives of individual parents versus the incentives of parental majorities.

It comes as no surprise, therefore, that most advocates of robust public educational authority do not challenge the current roles of individual parents as general custodians and informal teachers. Rather, they argue that in a democratic society the majority should decide what values and capacities formal schooling should develop in children. ${ }^{74}$ But if this claim is to be more than a majoritarian tour de force it needs justification in terms of the child's best interest. It is far too late in the day to argue that the mere fact that a majority believes value $\mathrm{X}$ should be instilled in every child constitutes sufficient evidence that value $X$ is actually in every child's best interest. To accept that principle would be to ignore the historical evidence that majorities have often been quite wrong on questions of value.

A more plausible majoritarian response might begin with the point that democratic majorities are themselves dominated by current and "former" parents. Family and education law, the argument would go, presumably reflects for the most part the majority view among experienced parents. Between the views of most parents and views of a parental minority, why should we not expect the former, on average, to be closer to the truth about children's best interests?

This argument, too, breaks down when we look at incentives. Parents care about other people's children because their (and their children's) welfare depends in part on how other children behave and on what kinds of adults they become. They may also care because the experience of loving their children has taught them to value all children. It is the rare parent, however, who cares as much about other people's children as about his or her own. Parents, if given authority over other people's children, are likely to impose on all children whatever values and practices they think would best serve the interests of their own children. For just that reason, the majority's judgment that instilling value $X$ is in all children's best interests may well merit deference as applied to the majority's children. The inference from incentives cuts the other way, however, when we ask whether the parental

74 The constitutional version of this argument is that whether or not the current political majority would agree, every child's formal schooling should include certain values and principles that the theorist regards as fundamental to liberal citizenship and adult autonomy. Amy Gutmann is an especially able proponent of this view. See notes 99-101 and accompanying text. For my discussion and critique of her position, see Section II. 
majority's judgment about value $\mathrm{X}$ is more likely to be correct than the contrary judgment of minority parents as applied to the minority's children.

The majoritarian rejoinder runs as follows: unless we have reason to think that the interests of minority children differ from the interests of majority children, the majority and the minority have really arrived at contrary judgments about the same issue, and one as to which their incentives are equally good, given that the welfare of their own children is at stake for both. The fact that more parents think value $\mathrm{X}$ is good for all children than think the contrary provides a neutral and sufficient reason to require that every child's formal education include value $\mathrm{X}$.

If liberalism is pluralist, however, this argument must be wrong. As a first approximation, all normal adults have equally good incentives to act in their own individual self-interest. Suppose then that a majority of adults judges that believing in-and acting in accord with-value $\mathrm{X}$ is in every person's self-interest. Do we deduce that the greater popularity of this conclusion about the good life justifies the coercive imposition of value $X$ on adults who reject it? Not if we take autonomy and toleration seriously; the freedom to choose one's own conception of the good life is fundamental. But don't we at least require dissenting adults to prove that their interests differ from those of the majority? On the contrary, as Rawls argues, pluralist liberalism rejects the coercive imposition of majoritarian judgments as illegitimate so long as the dissenters' contrary judgment about their own selfinterest is grounded in a reasonable conception of the good life. ${ }^{75}$ The dissenters may well believe that it is in every person's selfinterest to reject value $X$, in which case their disagreement with the majority rests on a claim about the human good, or they may simply believe that value $\mathrm{X}$ is bad for persons with their tradition and culture. Coercion is ruled out in either case.

Now, liberalism treats adults as self-governing in part because they have the best incentives to act in their own best interests. ${ }^{76}$ Consequently, because individual parents have the best

${ }^{75}$ See Rawls, Political Liberalism at 60-61 (cited in note 9).

${ }^{78}$ Of course, the liberal commitment to individual liberty may rest on other convictions, such as that freely chosen right conduct is intrinsically better than coerced right conduct. But it seems plain that we also think that individuals-because they bear the costs and benefits of self-regarding conduct-have the best incentives to discover and choose their own good, and are therefore more likely to be happy if left free to pursue their own conception of the good life than if subjected to the majority's conception. The liberal preference for persuasion over coercion draws strength from this same judgment: 
incentives to act in their children's perceived best interests, they have a claim to govern their children (and their children's education) that is closely analogous to their claim to govern themselves. By analogy, then, the majority acts illegitimately when it coercively overrides the judgment of the child's parents that value $X$ (which the majority thinks should be instilled in every child) is contrary to the interests of their child. It should be irrelevant whether the grounds on which the parents reject value $X$ involve their child's temperament, the family's tradition and culture, or a more comprehensive claim that value $X$ is harmful to all children. Majorities cannot legitimately override an adult's right to self-governance absent either tangible harm to others or consensus that the person's choices or opinions are unreasonable. Parental educational decisions should likewise stand absent consensus that the parents' choices are unreasonable and hence inimical to the child's best interest.

\section{The Argument from Parental Ideals}

The argument from parental incentives strongly supports allocating educational authority to individual parents rather than the liberal state or its delegates. That argument, however, does not directly respond to the widely held view that society has a compelling interest in ensuring that all children are adequately prepared to be good and productive citizens. Some parents, for example, might educate their children in ways that advance the children's private interests while shortchanging society. To meet this form of compelling-state-interest argument, I argue that parental educational authority should be regarded as an equally compelling interest. Given the cultural ideal of parenting that prevails in our society, such authority is central to the human flourishing of parents and children alike. Beyond that, the parental ideals described below both enhance parents' incentives and encourage parents to understand their children's best interests in ways that also meet society's needs. The long-run interests of liberal society are served, not disserved, by encouraging parents to treat the education of their children as a central part of their own life's work-and by giving them the authority necessary to do so. 
1. Children belong to (and with) their parents.

The question "to whom does the child belong" underlies the issue of educational authority over the child. At first cut, the answer seems self-evident: the child belongs to its parents. The child owes its conception to sexual intercourse between its mother and father, and its birth to the reproductive labor of its mother. Every cell of the child's body contains a unique genetic endowment, derived from its mother and father, that determines many of its characteristics and affects most others. As against the rest of the world, the child is its parents' "own." As Charles Fried puts it, to deny that parents have a "special title" to their children is to embrace the untenable proposition that "parents' reproductive functions are only adventitiously their own."

To be sure, one can imagine a liberal society in which children are put up at birth to be adopted by persons who wish to be parents, and who agree to love and nurture the child into adulthood. What is much harder to imagine, though, is why a liberal community would organize itself on these terms. The only answer that comes to mind involves the competing desires of those who wish to be parents but are incapable of having biological children. Given that the overwhelming majority of human beings are able and willing to procreate, however, the desires of those who are not can be met through adoption-a practice that simultaneously provides an exit option for unwilling biological parents. If we did not know which of us would be capable of having children, would we choose a regime that forbids adoption, a regime that allows adoption but gives a prior claim to natural parents, or a regime that requires all children to be raised by adoptive parents? The mixed regime clearly emerges as the winner, because it satisfies the deep desire to have one's own biological children, while providing insurance (via adoption) against the frustration of that desire. Wholesale rejection of special custodial rights for biological parents thus seems unjust as well as imprudent. ${ }^{78}$ In

${ }^{77}$ Charles Fried, Right and Wrong 153 (Harvard 1978).

${ }_{78}$ The drawbacks of an adoption-only regime seem very large. To forbid biological parents from raising their own children would drastically lower the benefits of begetting children. It would also lower the benefits of raising children for those adults to whom knowledge that their children are biologically their own is an important ground of satisfaction. Moreover, in a regime in which the only way to raise a child was to adopt one, there would be wasteful, high-stakes battles over both who should make adoption decisions and what rules should constrain that decision making. If the outcome were that the state made the decisions, we would be giving government a central role in constituting every family; if the market made them, we would be treating all children as tradeable 
fact, our society and virtually all others have elected to recognize such rights.

Indeed, the proposition that general custody, control of, and responsibility for the child lies with the child's parents stands as a fixed point in the thinking not only of the Supreme Court, but also of most liberal political theorists. Theorists as diverse as Ackerman and Gutmann agree that parents are entitled to live with and raise the children they procreate, and that these rights are inseparable from parents' obligations to care for and nurture their children. But this consensus breaks down when it comes to children's education. If we treated parental educational authority in the same way we treat parental custodial authority, this Article would hardly need writing. States do not substitute their judgments for parental ones when it comes to nourishing or nurturing children; they assert the narrower power to condemn some parents' conduct as inconsistent with any reasonable conception of good nourishment or nurturing. The paradigm of abuse and neglect would suggest that even if the state may legitimately rule out certain destructive conceptions of the good, it may not dictate that all educations adhere to its preferred conception of the good. Unfortunately, neither our practices nor our theories of education consistently conform to that paradigm.

Yet I believe that fair-minded, reasonable parents holding diverse comprehensive views would, upon due reflection, embrace this paradigm in the realm of education no less than those of nurture and nutrition. In what follows, I try to articulate the common values that unite these would-be parental educators despite their divergent conceptions of the good, and the reasoning that would persuade them to renounce parental majoritarianism for parental individualism.

2. Parenting is central to the flourishing of parents and children.

As individual parents, we do not claim a right to exercise arbitrary power over our children. We do claim a right to treat our children as central elements of our highest aspirations, as those whom we love best and whose good we most identify with our own. The project of parenting-having, nurturing, and educating one's children-is central to our conception of human flourishing. For this reason, the state cannot legitimately prevent 
us from raising our children by our own best lights, except where there is consensus ${ }^{79}$ that our aims or methods are in fact destructive of our children's well-being. ${ }^{80}$

Our society closely links the ideal of parenting to an ideal of companionate marriage. ${ }^{81}$ Ideally, parents become parents within the context of marriage, seen as a lifelong commitment to another adult based on mutual love and respect. ${ }^{82}$ Our decisions to enter into such relationships entail a set of judgments about each other, including that each is capable of loving and sharing a good life with the other. The partners in such a marriage may, of course, differ from each other in many of their values and beliefs. But the commitment to sharing a good life in a loving relationship implies as well that they hold certain fundamental values in common.

For most persons who enter into companionate marriages, the aspiration to have and raise children within the contexts of

79 In theory, one might argue for unanimity rather than consensus. Almost everyone may be wrong, and the few holdouts right. For purposes of this Article, however, I accept as sufficient what I take to be the Rawlsian defense of consensus as a practical criterion of truth or reasonableness: that if the vast majority of persons in a liberal society, themselves quite diverse in their conceptions of the good and the right, agree that some practice is destructive and unreasonable in human terms, this consensus-backed judgment should be treated as authoritative. See Rawls, Political Liberalism at 150-54 \& n 16 (cited in note 9 ).

${ }_{80}$ This formulation may prompt the objection that parents are not entitled to treat their children as means to the parents' well-being. The objection overlooks the interdependence that characterizes the well-being of family members. Parents who see their wellbeing as profoundly dependent on the well-being of their children are not treating their children as means in a morally disquieting way. Moreover, if there were any merit to this objection it would apply with at least as much force to the claim that liberal states should regulate the education of children to ensure the future well-being of society.

s1 I draw here on the historical account of marriage and child rearing in Brigitte Berger and Peter L. Berger, The War over the Family: Capturing the Middle Ground 14967 (Doubleday 1983), and on the insightful treatment of companionate marriage in Posner, Sex and Reason 45, 132-61 (cited in note 60). Posner defines companionate marriage as "marriage between at least approximate equals, based on mutual respect and affection, and involving close and continuous association in child rearing, household management, and other activities." Id at 45.

${ }_{82}$ This claim is not inconsistent with the increasing number of single-parent families in our society. Single parents do not typically choose that status in the belief that it is the ideal way to raise a child; more often, single parenting is the unintended consequence of sexual activity, broken marriages, abandonment, and so on. Nevertheless, the opinion that one parent is "just as good" as two parents is plainly on the rise in some circles. For documentation of this tendency, and refutation of its empirical basis, see David Blankenhorn, Fatherless America: Confronting Our Most Urgent Social Problem 65-83 (BasicBooks 1995). My sense, however, is that the view that one custodial parent may be "good enough" - which is consistent with recognizing that having two custodial parents is generally even better for the child-is far more widely held than the extreme position on which Blankenhorn focuses his critique. 
those relationships is among those values. ${ }^{83}$ Often, we choose our spouses not only because they seem good and loveable to us, but also because we judge that they will be good and loving parents. Moreover, our love for our marital partners increases our willingness to incur the responsibilities of child rearing. Our children are an expression of our marital love. We see both ourselves and our beloved spouses in our children, and we love them all the more because we can trace both their existence and their natures to the couple we constitute.

Our society recognizes the worthiness and importance of these aspirations in a variety of ways. It is, for example, unquestioned in our society that the state may neither forbid persons from marrying and having children nor force them to do so. Even our deep divisions over issues such as abortion attest to the underlying consensus that what is best for children is to be raised by parents who live together in a stable, loving relationship. ${ }^{84}$ That ideal explains both the pro-choice refrain that all children should be wanted and loved and the pro-life rejoinder that mothers should allow loving parents to adopt their unwanted children.

Underlying this consensus is a conviction shared by persons who subscribe to widely divergent conceptions of the good life: that the capacity to enter into loving, long-term relationships with other human beings is central to human flourishing throughout. ${ }^{85}$ That capacity grounds companionate marriage, friendship in its many forms, and parenting itself. We judge that children should live with, and be raised by, their parents because we recognize that parents are best situated to develop this capacity. Parental love and nurturing, the "continuity of care" parents provide ${ }^{86}$ and the example of their spousal love involve children

${ }_{83}$ The traditional requirement that marriage partners be of opposite sexes excludes homosexual couples from legally recognized companionate marriage. I do not address the legitimacy of that exclusion.

84 There is, by contrast, disagreement about whether same-sex couples are as likely as heterosexual couples to be good parents. The key point for purposes of the present argument, however, is that those who favor extending legal recognition to same-sex marriage and parenting do not reject the idea that children benefit from being raised by a loving couple; they simply argue for a more inclusive conception of what constitutes a loving couple.

Bs Indeed, one might surmise that this capacity supplies the foundation for the "two moral powers (a capacity for a sense of justice and for a conception of the good) that Rawls argues are central to the status of persons as "free." Rawls, Political Liberalism at 19 (cited in note 9).

${ }_{85}$ See Joseph Goldstein, Anna Freud, and Albert J. Solnit, Before the Best Interests of the Child 4 (Free Press 1979) ("[A] child's need for continuity of care by autonomous parents requires acknowledging that parents should generally be entitled to raise their 
from infancy on in a nexus of loving, long-term relationships that provide the necessary foundations for trusting and caring for others throughout life.

3. Why nurturing children is inseparable from shaping their values.

There is a consensus in our society, then, that children should ideally be raised by loving, mutually committed parents, and that the parents should ordinarily be the child's natural progenitors. ${ }^{87}$ This consensus rests on the judgments that parents are most likely to love their child, to act in the child's best interest as they perceive it, and to develop the child's capacity for loving, caring relationships with others. The next step in the argument is to consider what these judgments imply for the allocation of authority to guide the formation of the child's values and conception of the good life. Here I argue that loving and nurturing a child cannot sensibly or practically be divorced from shaping that child's values.

We count on parents to love their children and desire their children's good. All thoughtful parents welcome society's insistence that they provide for their children's physical needs and basic social and intellectual development. But these minimum standards for parenting neither exhaust parental aspirations nor circumscribe parental authority. In desiring the good for their children, parents desire more than just the minimum human goods on which there is social consensus. Rather, we wish our children to share in the good life as we (diversely) conceive it, to flourish as we understand human flourishing. To these ends, we seek to pass on to them not only our fundamental values and beliefs, but also the character to live in accordance with them.

I do not assert that all committed parents share a common conviction about how best to achieve this goal, or even that they define the goal in quite the same way. For example, some parents

children as they think best, free of state interference.").

${ }_{87}$ It is a fair implication of the ideal I have sketched that public opinion prefers twoparent to single-parent families on the ground that children are more likely to flourish in the former. It does not necessarily follow, however, that society should coercively intervene to promote two-parent over single-parent families, and I take no position on such issues here. See generally Iris Marion Young, Mothers, Citizenship, and Independence: $A$ Critique of Pure Family Values, 105 Ethics 535 (1995) (criticizing Galston's proposition that the liberal state should privilege two-parent families). The implication that matters for present purposes is rather that society should favor the educational choices of all parents who stand in a custodial relationship to their children. 
may follow Ackerman in subordinating most other values to their child's autonomous self-development. For these parents, however, a child who adopted a single belief system at an early age and then steadfastly refused to confront or examine alternatives would, one suspects, be a major disappointment that these parents would work hard to prevent or overcome.

Different parents will distinguish in different ways between core values they are convinced their child must, if at all possible, be induced to adopt, and secondary values they prefer, but on which they are not prepared to insist. Some parents may draw that line to correspond to the value judgments on which there is a secular social consensus. For them, it may be an article of faith that their child should be left free to choose whatever values he or she likes provided these social minimums are satisfied. Others will be convinced that theirs is the one true or best way of life and that they should raise their children to accept it comprehensively. Despite these differences, a crucial commonality runs throughout the many variations: all of these parents wish their vision of education to be given full effect. And insofar as they are committed and loving parents, their desires to educate their child in what they see as the best way are central to their understandings of themselves and of their obligations to their children.

In short, conscientious parents conceive their educational obligations comprehensively. They try to equip their children to live well, not merely to survive. Our public culture endorses and indeed relies on this aspiration. But these benign parental aspirations are not the only reason why parenting inherently involves shaping the child's values. Children need and, in a variety of ways, will seek out guidance, direction, and meaning from those they depend on and love. This tendency should hardly be surprising. Even loving relationships between adults are rich in value reinforcement and development. We often discover what matters to us by learning what matters to those we love. Similarly, the nurturing relationships between parents and children are both value laden and, for the child especially, value forming. The labor of raising a child routinely involves the examination and application of many parental values. Issues of justice, moderation, courage, and good judgment surface continuously. What punishment is fair for this offense? How much of this pastime or pleasure is too much? How can we help our children deal with this or that fear? These are staples of parenting quite as much as affection, shared activities, and providing for basic needs. 
Perhaps, in theory, we can imagine a parent who strives to preserve a firm distinction between his or her own comprehensive values and those called into play in educating a child. Most of us, however, are neither artful enough to educate in this way nor convinced our children would benefit from the attempt. Instead we draw on the traditions, faiths, and philosophies that infuse our values with whatever coherence and unity they have. ${ }^{88} \mathrm{We}$ educate our children toward the good and the right as we understand them, not because that is the only understanding we can imagine, but because it is the only understanding we are competent to apply in our daily lives. Raising one's children may, of course, prompt us to question some of our values even as we apply others. But for most people that questioning occurs within the larger context of a system of values. For most of us, the only practical option, when we come to teach our children the meaning of justice, is to teach them justice as we conceive it to be. Consequently, teaching by one's own best lights is oftentimes a matter not only of conviction, but also of necessity.

\section{Majoritarian control of the child's values is unjust.}

We have now seen why the consensus in favor of parental nurturing should, on due reflection, lead to a parallel preference for parental educational authority in matters of values and the good life. The argument for parental educational authority, however, also rests on justice and consistency. Consider what it would mean were the state to insist that all parents educate their children in accord with the majority's preferred conception of the good. Most parents would presumably find themselves in the political majority. These majority parents would of course remain free to educate their children in accord with their basic values. Beyond that, their efforts would be reinforced by the state's endorsement of those values. Minority parents, by contrast, would continue to have general custody of their children, and with it the responsibility for nurturing them. But insofar as their conception of the good clashed with the majority's, they would be compelled to teach contrary to-or, at least, to refrain from teaching in accord with-their beliefs.

Although this stage of the inquiry sounds in political theory rather than constitutional law, it should be obvious that such 
viewpoint-based restrictions on parents' efforts to pass on values to their children raise serious free speech concerns. ${ }^{89}$ Putting these constitutional questions aside for now, let us try instead to articulate the problem in human terms. Dissenting parents would find themselves in an impossible predicament. The state expects them to love and care for their children, yet forbids raising them by the parents' own best lights. As we have seen, nurturing one's children cannot practicably be divorced from transmitting one's values to them. Although loving parents distinguish between what is best for their child and what they would choose for themselves, that distinction breaks down when they see the values they are trying to instill as central to the good life. Imagine asking traditionalist parents to raise their child as a feminist, or feminist parents to raise their child as a traditionalist. The project is self-contradictory and incoherent.

It is also unjust, as against the baseline of liberal toleration for the reasonable comprehensive views of others. Why should the mere fact that some parents are in the majority entitle them to teach their children as they think best, while using the state's coercive powers to prevent minority parents from doing the same? Because there is little reason to expect the majority's values to be better or more reasonable than the minority's, the affront to liberal pluralism seems plain.

5. Majoritarian interference with parental transmission of values is likewise unjust.

I have now offered a theoretical defense of the core parental educational right endorsed by the Supreme Court in Pierce and reaffirmed (in its religious dimension) in Yoder: the right to direct and control the value-laden education of one's own children. ${ }^{90}$ But this parental right does not necessarily preclude the existence of the state's parallel right to teach the child its preferred conception of the good. Just such a right is the centerpiece of Amy Gutmann's Democratic Education. Gutmann divides educational authority into dual spheres: home education, within which parents have exclusive authority to promote their own values, and formal schooling, within which the state has (at least in theory) exclusive authority to promote its preferred values. ${ }^{91}$

See Section IV.C.

${ }_{90}$ Pierce, 268 US at 534-35; Yoder, 406 US at 213.

91 Gutmann, Democratic Education at 32-33, 50 (cited in note 1). Gutmann makes some prudential concessions that would allow the continued existence of private schools, 
This compromise is obviously unstable, given that the state controls the definition of the two spheres: expand formal schooling, and the domain of the home shrinks correspondingly. But the more fundamental problem is that the paradigm of the state battling with minority parents to win the child's allegiance is both subversive of parental nurturing and authority, and counter to the widely held and reasonable judgment (explicated below) that the child needs to receive a coherent education shaped by some controlling conception of the good.

True, even in the scenario Gutmann envisions parents may still use their considerable influence to instill their values in their children. If the state's right to communicate its views about the good life to dissenting children were limited to short, infrequent messages, the incursion on parental educational authority would be indistinguishable from ordinary, unproblematic government speech. That, however, is not what Gutmann and other advocates of state-backed educational values and virtues have in mind. Day in, day out, in the context of formal schooling, the children of dissenting parents are to be taught the state's established wisdom concerning the human good, and made aware (either explicitly or by implication) that this authoritative teaching clashes with the values they have been taught at home.

There are good reasons to reject this sort of educational dualism. First, this places the strongest educational influences in the child's life at cross purposes and sows confusion and discord rather than coherence and stability. ${ }^{92}$ Second, consider each person's interests as a potential parent. Almost all of us want the education of our own children to be conducted in accord with our conception of the good life. ${ }^{93}$ We might therefore agree to respect one another's preferences on this point by pledging not to use state power to impose anyone's conception of the good life on others' children through formal schooling. To be sure, we might resist entering into such an agreement, especially if we thought our viewpoint would prevail in the political process. At bottom, some of us may believe that our own conception of the good should ideally inform every child's entire education, or at least

but only on condition that they conform to the "educational standards, both curricular and noncurricular, essential to democracy." Id at 118.

92 See Section I.D.6.

${ }^{93}$ Some parents from dissenting or minority traditions may choose to educate their children in the majority's culture and values to facilitate their entry into the mainstream. Because they rest on prudential judgments about the child's best interest, choices of this kind do not contradict the statement in text. 
every child's formal schooling. The real issue, however, is not what we would think best, but whether it is reasonable for us to impose our ideals on others through the coercive power of the state.

The familiar Rawlsian image of the veil of ignorance will help explain why such impositions are unreasonable. ${ }^{94}$ Assume that we are committed parents, but that we do not know whether our values will be in the majority or the minority. Which regime would we prefer? There would, I submit, be consensus in favor of exclusive parental educational authority. We know that we care more about our own children than we do about the children of those who see the good life differently than we do. We therefore care more about having the undisturbed authority to educate our children in accord with our conception of the good than we do about expanding that authority to encompass the formal schooling of children whose parents adhere to different conceptions of the good. In the sort of regime Gutmann describes, minority status is much more threatening than majority status is rewarding. We would therefore reject it, choosing instead a regime that would let us direct both the home and formal education of our children.

6. Majoritarian interference with parental education is not in the child's best interest.

The previous argument suggested that undivided parental educational authority is in the enlightened self-interest of parents. The next argument is intended to explain why such authority is in the interest of children. Despite our differing conceptions of the good life, most parents agree that children need to be raised in some coherent, comprehensive tradition that will ground their values and beliefs. Again, different traditions imply different parental attitudes about crucial pedagogical issues such as when and under what circumstances to expose the child to alternative values and ways of life. Yet whether their tradition is rationalist or fideist or a mixture of the two, most parents locate themselves within a tradition and believe it is best that all children be educated within some such tradition.

Why do so many parents share this belief, even as applied to traditions other than their own? Because our own experiences, both as children and as parents, have convinced us that for chil- 
dren to learn what it is to have a way of life, they must first be given a way of life. ${ }^{95}$ As they develop, children learn to apply, extend and question this "second nature." As adults, they may reject their parents' way for one quite different. A choice of that kind, however, will still owe much to the standards of coherence and meaning that the child learns through having had an initial, formative tradition within which to develop. ${ }^{96}$

I do not claim that there is any consensus in favor of these judgments, although they are unquestionably widespread. Rather, I suggest that the belief that children need to be given a comprehensive, stable initial scheme of values is at least as reasonable as the contrary judgments Ackerman and, to a lesser extent, Gutmann arrive at. ${ }^{97}$ Gutmann might reply that while the child needs an early, unquestioned education in parental values, exposure to diverse conceptions of the good is imperative by the time formal schooling commences. ${ }^{98}$ I shall respond more fully to this argument, and to the conception of critical rationality on which it rests, in Section II. It seems untenable, however, to suggest that most parents in our society believe it is good for children to serve two educational masters. No one, after all, proposes that the children of majority parents should be given a formal education dominated by the values of dissenting parents.

The truth of it, I suggest, is that majority parents will find themselves tempted by arguments such as Gutmann's to have it both ways: to use the state's power to privilege and enhance their efforts to pass on their values to their children, while undermining the ability of parents in the minority to do the same. They believe it is best for children to receive a single, coherent education. But insofar as they choose to make certain comprehensive, publicly chosen values a mandatory feature of every child's edu-

${ }_{25}$ These convictions draw support from our public culture's commitment to toleration. A strong cultural norm of toleration gives rise to the widespread sense that other ways of life are not evil, even if they are imperfect or deficient, and concomitantly that many other conceptions of the good share much common ground with one's own. Parents who are privately tolerant of the lives other parents choose to lead are therefore more likely to think that the benefits of parental value-direction are great for other people's children, not just for their own. The causation can also fruitfully run the other way. Conscientious parents may become more tolerant as a result of coming to admire and respect the parental nurturing of persons whose views differ greatly from their own.

96 I thank Chai Feldblum for helpful conversations on this point.

97 My formulations throughout this paragraph reflect my considerable debt to Ackerman's illuminating explication of liberal neutrality in Social Justice (cited in note 2). See, for example, id at 15-16 (using hypothetical dialogue to illuminate the concept).

${ }_{s 8}$ See, for example, Gutmann, Democratic Education at 44,46 (cited in note 1) (explaining that otherwise repression and discrimination remain unchecked). 
cation, these majority parents would deny dissenters' children the benefits of that belief. The question is why we should see this as a legitimate move rather than a power grab, an attempt by the majority to give its values a competitive advantage in the broader social contest among differing conceptions of the good. Unless the majority can make a case that its conception of the good is somehow intrinsically superior, this use of state power stands as an unjustified departure from liberal neutrality.

\section{AMY GUTMANN'S COMPULSORY DEMOCRATIC EDUCATION: A CRITIQUE}

The best and most influential argument for mandatory education in certain liberal democratic values is Amy Gutmann's Democratic Education. Gutmann does not purport to offer a "foundationalist" account of the best education for all times and places..$^{99}$ Instead, she argues that her conception of democratic education best conforms to our considered intuitions about liberal democracy. Our shared understanding of liberal democracy, she tries to show, entails a set of substantive educational commitments that should inform every child's formal education. ${ }^{100} \mathrm{I}$ shall argue that her project fails. ${ }^{101}$ There is no consensus in favor of Gutmann's conceptions of liberal democracy and of the good life, and she fails to establish the unreasonableness of the competing conceptions she criticizes.

\section{A. The Argument for "Critical Deliberation"}

Gutmann's lead arguments fall into two main categories: arguments for constitutionalizing democratic education as she conceives it and arguments for rejecting exclusive parental educational authority. Her core affirmative claim is that liberal democracy entails a shared commitment to develop children's capacities for critical deliberation among competing conceptions of the good life and the good society, while instilling commitments to toleration, equality, and liberal democracy. She would constitutionally establish this "democratic civil religion," and require all schools, public and private, to teach it. ${ }^{102}$ She would, likewise,

S9 See id at 21-22.

100 Id at 41-47.

${ }^{101}$ I have been helped throughout this Section by William Galston's discussion of liberal civic education and his criticisms of Gutmann's work. See Galston, Liberal Purposes ch 11 (cited in note 12).

${ }^{102}$ Gutmann, Democratic Education at 104 (cited in note 1). 
forbid home schooling because it enables parents to encroach on the public sphere of formal education. ${ }^{103}$ Moreover, she makes clear that the fundamentals of this system of democratic education should be insulated from majoritarian override. ${ }^{104}$ Compared to current law, her theory would radically curtail parental constitutional rights and erect countervailing public educational obligations that bar parents from using democratic politics to expand their educational authority.

To defend these far-reaching proposals, Gutmann argues that parents who seek to instill "uncritical acceptance" of one way of life in their children are unreasonable and antiliberal. ${ }^{105}$ Unless children are exposed to diverse conceptions of the good, they will not develop the capacity for critical deliberation that she regards as central to their future well-being as adults and citizens. Thus, while Gutmann would allow parents to teach their values in the home, she categorically denies them the right to "insulate their children from exposure to ways of life or thinking that conflict with their own."106

Each of these arguments rests on the proposition that the developed capacity to engage in critical deliberation is essential to individual freedom and human flourishing. ${ }^{107}$ Gutmann, of course, does not assert that liberal democracy dictates a single, uniform conception of the good life. But she does argue that the various conceptions of the good life that are compatible with liberal democracy all share a common feature: the persons who hold these conceptions choose them freely and deliberately

103 Id at 234 (" $[\mathrm{P}]$ arents are not free, for example to keep their children home from school .....").

104 Id at 104.

105 Id at 44.

108 Id at 29.

107 Many contemporary liberal theorists endorse this proposition. In addition to Gutmann, see Brian Crittenden, Parents, the State and the Right to Educate at 203 (cited in note 1) ("E[]ducation in the tradition of critical rationality should be supported by the liberal democratic state."); Don Herzog, Happy Slaves: A Critique of Consent Theory 242 (Chicago 1989) ("[P]arents need to teach their children to be critical thinkers or at least need to tolerate others' so teaching them."); Stephen Macedo, Liberal Virtues 269 (Oxford 1990) ("Liberal persons are distinguished by the possession of self-governing reflective capacities," an ideal that "involves developing the self-conscious, self-critical, reflective capacities that allow one to formulate, evaluate, and revise ideals of life and character."); John White, Two National Curricula-Baker's and Stalin's: Towards a Liberal Alternative, 36 Brit J Educ Stud 218, 230 (1988) (Liberal government's educational role "means helping to build up in [citizens] those dispositions and forms of understanding which are required for autonomy."). 
through critical deliberation among competing conceptions of the good. ${ }^{108}$

For two reasons, this benchmark favors what we might call reason-centered conceptions of the good and disfavors their faithcentered counterparts. First, people do not ordinarily come to live a life of mysticism, piety, orthodoxy, or traditionalism by critically evaluating the supposed advantages and disadvantages of such a life against a menu of alternatives. Second, the demand that each person choose a way of life through rational deliberation presumably carries over to making value choices within a way of life. Consequently, using rational deliberation as a litmus test for liberal reasonableness promotes conceptions of the good in which critical reason plays a pervasive, unifying role in determining one's values. Conversely, as Gutmann freely acknowledges, "[r]ational deliberation makes some ways of life-such as that of the Old Order Amish-more difficult to pursue insofar as dedication to such lives depends upon resistance to rational deliberation. ${ }^{109}$

Gutmann's conception of critical or rational deliberation thus implies a comprehensive rationalist ideal, rather than only a limited commitment to developing in every child the capacity for practical, instrumental reason as commonly understood. Traditionalist parents agree that education should develop the child's capacity to evaluate alternatives and make considered choices. Unlike Gutmann, however, they believe the child's reason should develop within the framework provided by their traditional values, rather than be transformed into the judge and critic of those values. ${ }^{110}$ What, then, justifies Gutmann's assertion that liberal democracy requires each of us to define our freedom in terms of autonomous selfhood and to accept critical reason as our personal sovereign?

Gutmann is well aware that her conception of critical deliberation is not "neutral among all ways of life-even all decent ways of life."111 But she argues that her preference is legitimate because "[r]ational deliberation is the form of freedom most suit-

${ }^{108}$ See Gutmann, Democratic Education at 27 n 17, 39-40 (cited in note 1).

109 Id at 44-45.

110 Beliefs of this kind, of course, are entirely consistent with habitually explaining to the child the reasons why one must or must not do something. For traditionalist parents, however, those reasons must be derivable from the principles their tradition recognizes as valid.

111 Gutmann, Democratic Education at 44 (cited in note 1). 
able to a democratic society." although we cannot agree on which conceptions of freedom and goodness should prevail, we can reach consensus that "conscious social reproduction" is the most inclusive "educational end" available to us, and that developing every child's capacity for rational deliberation is an essential means toward that end. ${ }^{113}$ We are committed, as liberal citizens, to reaching agreement on some conception of liberal, democratic education. This commitment presupposes that we aspire consciously and collectively to shape our children, and thereby our society, through education. In other words, we aspire to engage in conscious social reproduction.

What we want for ourselves as citizens, Gutmann then argues, we should also want for our children as future citizens. We must therefore agree to give our children an education calculated to make them "capable of participating in collectively shaping their society." (which, at bottom, often involve choosing among competing conceptions of the good society) requires that citizens have well developed capacities for critical reason. No parent, therefore, can legitimately object to the requirement that every child's formal schooling develop his or her capacity for rational deliberation. ${ }^{115}$ And that requirement rules out any education that stunts the capacity for critical reason by teaching uncritical acceptance of one way of life.

This intricate reasoning is deeply problematic. Why would we think that every liberal democrat adheres to an unqualified commitment to reaching public consensus on a comprehensive educational ideal? Any such commitment is far more likely to be partial and provisional. We might well believe that consensus on certain general values-for example, law-abidingness, toleration, and respect for other persons-is both attainable and indispensable. Once we realize that this consensus is incomplete, however, and that our reasonable disagreements about freedom, virtue, and the good life are ineradicable, we might well abandon the elusive search for a more comprehensive public consensus on education. ${ }^{116}$

112 Id at 45 .

113 Id at $39,42$.

114 Id at 39 .

$115 \mathrm{Id}$.

116 See Rawls, Political Liberalism at xvi (cited in note 9) (“[A] plurality of reasonable yet incompatible comprehensive doctrines is the normal result of the exercise of human reason" in a modern democratic society.). 
Instead, we would find it in our enlightened self-interest to give parents exclusive (not unlimited) educational authority over their own children. Behind the veil, we would refuse to adopt Gutmann's comprehensive conception of critical deliberation because we and our children would gain far less if we turned out to share Gutmann's rationalist ideal than we would lose if we turned out to disagree with it. We would renounce the authority to control the education of others' children in order to preserve what we value more-our authority over our own.

Gutmann's best reply to this argument, I think, is that no reasonable parent has anything to fear from critical deliberation. If your child rejects your way of life after critically evaluating how it compares to a range of reasonable, alternative conceptions of the good, you cannot reasonably complain, especially when you have had ample opportunity to make the case for your own beliefs. Again, however, this contention unjustifiably privileges critical reason. The capacity for critical deliberation is not like a bodily organ whose well-functioning furnishes us with a noncontroversial criterion for choosing some educations over others. Human beings reason and calculate, and we can agree that these capacities should be developed in all children. But to appeal to the capacity for critical deliberation is to make a controversial judgment about the extent to which we should rely on reason to govern our lives, and speaking in terms of "capacities" does not suffice to render that judgment incontestable.

Specifically, because human beings also make commitments and adhere to unprovable, deeply felt beliefs, we must recognize the human capacity for allegiance and faith as well. Indeed, as Gutmann acknowledges, a life without faith in, or commitment to, any values or principles would be neither reasonable nor good. ${ }^{117}$ Thus, just as we can agree that children need to master basic reasoning, we can agree that children need to have some beliefs instilled in them as matters of faith and commitment. Beyond these minimums, however, there is no consensus about how to strike the balance between reason and faith. Educations that foster comprehensive faith may place less emphasis on reason, but by the same token educations that foster critical reason may place less emphasis on faith. To Gutmann's charge that uncritical education stunts children's capacity for critical deliberation, religious and traditionalist parents can with equal reason reply that critical education deprives them of the capacity for 
faithful allegiance to a tradition. Consequently, we have no just cause to mandate formal schooling that is based on rationalist values at odds with what traditionalist parents believe.

\section{B. The Argument that Traditionalist Education is Brainwashing}

Gutmann's proposed use of state power to promote rationalist education prima facie violates the liberal norm of neutrality among reasonable conceptions of the good life. To meet this objection, Gutmann advances a second line of argument: that many religious traditionalists adhere to unreasonable conceptions of the good that fall outside the proper domain of liberal neutrality. ${ }^{118}$ For prudential reasons, we may not want to suppress traditionalist education in the home, but we can and should subordinate it to critical education in the schools. ${ }^{119}$

Gutmann's attempt to show that traditionalist ways of life are unreasonable involves what we might call the argument from brainwashing - that is, the contention that children who receive an orthodox, noncritical education are deprived of freedom as liberals understand it. ${ }^{120}$ At the core of this argument is the claim that parents have no right to impose their way of life, even on their own child, "at the cost of depriving her of the capacity to choose a good life." ${ }^{21}$ This proposition has powerful intuitive appeal within a liberal framework. But we need to consider more closely what would constitute a deprivation of this capacity. Numberless children, after an initial education in religious or ideological orthodoxy, have renounced their parents' faith later in life. That fact alone dispels the notion that a comprehensive traditionalist education precludes meaningful choice. Nevertheless, the fear Gutmann evokes is that those who remain true to their hereditary education did not really choose that path-they uncritically and unselfconsciously followed it. Because their parents have tried to "insulate [them] from exposure to ways of life

${ }^{118}$ See, for example, her discussion of creationism, which she treats as an "unreasonable" belief in light of secular scientific standards. Id at 101-07.

119 Id at 104. The difference between Gutmann and Rawls on this issue is striking. Rawls "counts many familiar and traditional doctrines-religious, philosophical, and moral-as reasonable even though we could not seriously entertain them for ourselves," see Rawls, Political Liberalism at 59-60 (cited in note 9), and suggests (though guardedly) that "except for certain kinds of fundamentalism, all the main historical religions . . . may be seen as reasonable comprehensive doctrines." Id at 170.

120 Id at 40 . Galston uses the term "brainwashing" to describe Gutmann's position. See Galston, Liberal Purposes at 254-55 (cited in note 12), but Gutmann herself does not.

121 Gutmann, Democratic Education at 40 (cited in note 1). 
or thinking that conflict with their own,"122 they have been denied the opportunity to make a meaningful choice. Consequently, their parents have wronged them, whether or not, as adults, these children would pronounce themselves content.

This argument depends on postulating that a human life is fully good only if chosen "freely" in a special and restrictive sense. By conventional liberal standards, a child whose habits and inclinations are shaped by a traditionalist education remains free to choose between that life and all the others. Of course, if traditionalist parents did not think that "exposure" to conflicting ways of life would increase the risk that their children would choose wrongly, they would not take such pains to shield them. But how is this different from rationalist parents who seek to shield their children from such secular sins as smoking, unsafe sex, racism, and sexism? In neither case is it true that the child who follows in its parents' footsteps had no meaningful choice. What makes choice meaningful in conventional liberal terms is the presence of several circumstances: (1) the child has received an education in basic thinking and reasoning; (2) the child has been educated in a tradition in which reasoning and deliberation, at least within the framework of that tradition, is valued and encouraged; ${ }^{123}$ (3) the child lives in a pluralistic society that enables him or her to search out information about alternative ways of life; $;^{124}$ and (4) the parents' legal authority over the

122 Id at 29.

${ }^{223}$ See Alasdair MacIntyre, Three Rival Versions of Moral Enquiry 100 (Notre Dame 1990) (suggesting that every "developed tradition[ ] of intellectual and practical enquiry ... has its own internal problematic, that set of questions which arise within the tradition and to the provision of answers to which, or at least to progress towards the provision of answers to which, the adherents of that tradition are committed"). In addition, as Gutmann herself has acknowledged in her more recent writings, "[t]he criteria for assessing conflicts may come from within social understandings." Amy Gutmann, The Challenge of Multiculturalism in Political Ethics, 22 Phil \& Pub Aff 171, 189 (1993). She offers an illuminating example: the availability of an argument that is "reasonable by the interpretive terms of Orthodox Judaism" for the conclusion-which conflicts with orthodox understanding - that women as well as men should engage in Talmud study "because both men and women are created in God's image." Id at 189. Tradition itself can thus provide the means for calling into question particular practices or understandings within that tradition.

${ }^{124}$ See Galston, Liberal Purposes at 255 (cited in note 12) (arguing that the basic pluralistic features of liberal society "make it virtually impossible for parents to seal their children off from knowledge of other ways of life"); Simon A. Longstaff, Democratic Education and the Curriculum Safety-net: a tantalising illusion?, 23 J Phil Educ 93, 101 (1989) (" $[\mathrm{A}]$ child receiving an education in or based on [a particular way of life] is bound to encounter a range of counter-examples backed by positively persuasive reasons ... that can be evaluated."). 
child is limited along liberal lines in duration, intensity, and extent. When these conditions are satisfied, as they virtually always will be for traditionalist children in America today, the outcome of a value-laden, parentally imposed education should be seen as meaningfully chosen. ${ }^{125}$

Indeed, employing a more exacting standard than this would require us to condemn Gutmann's critical education no less than the nonrationalist educations she attacks. All ways of life, including those that emphasize critical rationality, require immersion, inculcation, and habituation. Receiving a thoroughgoing rationalist education precludes a child from receiving a thoroughgoing religious one, and vice versa. Consequently, the child who receives an education in critical rationality has no greater or more meaningful "choice" than one who receives a religious or traditionalist education.

Consider in this connection the "capacities" for reason and for faith discussed in the preceding Section. ${ }^{126}$ Quite clearly Gutmann is not proposing that all children receive an education that equally develops these two capacities. ${ }^{127}$ She might be critical of rationalist parents who object to exposing their children to, say, a description of what religious fundamentalists believe. But she surely would not be critical of rationalist parents who objected to an education that taught belief in a true faith, so that children could know whether they preferred that orientation to the human good to more rationalist world views. Yet without this internal experience of what a life of faith and tradition entails,

${ }^{225}$ Even if we were persuaded that there will be particular instances in which these conditions will not be satisfied, the appropriate remedy would not be to enact a universal educational norm of critical rationality. That solution, curtailing as it would the liberty of all families, is not necessary to forestall the abuses of a few. As E.G. West points out, we do not enforce the prohibitions against child abuse or malnutrition by specifying how parents should discipline or feed their children; instead we monitor suspected instances of excessive discipline or malnourishment. Education and the State: A Study in Political Economy 253-54 (Liberty Fund 3d ed 1994). If the notion of "brainwashing" were, by analogy, to become a third category of abuse warranting state intervention, a selective (and neutral) strategy of this kind would seem called for. We might, well conclude that it is wrong for either traditionalist or rationalist parents to place their children under extended "house arrest" for refusing to adopt some cherished parental value. But the wrong would lie not in the traditionalist (or rationalist) content of the value, but in the harshly coercive means whereby parents tried to inculcate it.

${ }^{128}$ See note 117 and accompanying text.

${ }^{227}$ Some traditionalists, and some rationalists, would see this as a quixotic project. I am neither assuming nor rejecting that view. It is worth noting, however, that some persons who would by any measure be considered rationalists hold certain fundamental beliefs on faith, and indeed do not believe that one could hold those beliefs other than on faith. Equal development of both capacities might well be an aspiration for such persons. 
how can one possibly say (using Gutmann's demanding standards for meaningful choices) that the child has had a meaningful choice to accept or reject traditionalist ways of life-particularly if the child's home education has also been a rationalist one?

Gutmann's own vision of democratic education confirms this analysis. She calls for an education that will instill deep commitments to critical reason, toleration, and equality. These secular democratic commitments ground the critical reasoning about politics and the good life in which children will be taught to engage. Thus, Gutmann's ultimate agenda is not so much to substitute reason for faith as to substitute faith in a particular conception of human reason for faith in religious and other traditions. She makes plain her belief that it would be best if formal education could "convert children away from the intensely held [religious] commitments of their parents." 128 But unless the intensely held secular commitments that structure her "democratic civil religion ${ }^{\prime 129}$ are shown to be necessary to liberal democracy, it would violate liberal pluralism to impose them on the children of dissenting parents.

C. The Argument that Traditionalist Education is Intolerant and Antiliberal

Section II.B argued that traditionalist educations that shield children from exposure to alternative ways of life are, in general, fully compatible with liberal democracy. Gutmann's critique of traditionalist education, however, contains another, more sweeping indictment. She asserts that traditionalist parents frequently teach their children to be intolerant, disrespectful of others, and subservient to religious authorities. ${ }^{130}$ Because the health of liberal democracy depends on a citizenry that is tolerant, respectful of persons, and independent minded, these traditionalist educations shortchange society and children alike. The liberal state can legitimately intervene, through formal education, to teach these liberal virtues to the children of traditionalist parents.

This argument rests on a highly partisan and contestable understanding of the virtues necessary to sustain the liberal state. Religious traditionalists are obviously capable of civic toleration-that is, of refraining from the use of private or public force

${ }_{128}$ Gutmann, Democratic Education at 121 (cited in note 1).

129 Id at 104.

130 Id at 29-31. 
to impose their way of life on others. As William Galston argues, "[c]ivic tolerance of deep differences is perfectly compatible with unswerving belief in the correctness of one's own way of life. It rests on the conviction that the pursuit of the better course should (and in many cases must) result from persuasion rather than coercion-a classic Lockean premise that the liberal state does have an interest in articulating." premise that the major traditionalist denominations in America have long endorsed.

Gutmann rejects this reasoning because she judges that religious traditionalists are often privately intolerant of conduct and values that their traditions regard as sinful, even salvation threatening. But private intolerance is neither unique to traditionalists, nor necessarily a bad thing for liberal societies. Every commitment to virtue entails some objection to vice. The freedom that liberalism promises therefore includes the freedom to reject, criticize, and condemn some of the choices others make. Civic toleration is necessary to liberal democracy because civic intolerance can crush individual liberty. Private toleration, by contrast, is not necessary to liberal democracy because liberal societies relegate private intolerance to the realm of persuasion, deprive it of all force in the public arena, and keep it safely within constitutional bounds. At least if we accept the classical understanding of what distinguishes liberal regimes, this claim is empirically verifiable: constitutional government, democratic elections, the freedoms of speech and religion, stable property rights, and robust markets $^{132}$ have frequently coexisted with widespread private intolerance of the kind Gutmann condemns.

Moreover, although we can presumably agree that excessive private intolerance is undesirable because it can spill over into the public arena, there is no consensus on what constitutes excess. For example, Gutmann condemns many religious parents for having "implicitly fostered (if not explicitly taught) disrespect for people who are different."133 But she offers no evidence that any major religious sect in America today demands a theocracy, calls for the repeal of the Religion Clauses, or repudiates the principles of classical, limited-government liberalism. ${ }^{134}$ Why,

131 Galston, Liberal Purposes at 253 (cited in note 12).

${ }^{132}$ See Stephen Holmes, The Anatomy of Antiliberalism 4 (Harvard 1993) (describing the characteristic features of liberal regimes); Galston, Liberal Purposes at 220 (cited in note 12) (same).

133 Gutmann, Democratic Education at 31 (cited in note 1).

136 As John Garvey notes, "American Protestant fundamentalists stop short of arguing 
then, should we characterize religiously based antipathy for what is seen as, say, a gravely sinful lifestyle as "disrespect" for "people who are different?" The vast majority of religious traditionalists do not teach their children that it is appropriate to hate unbelievers, to violate their civil rights, or to expel them from our midst. True, many of them do teach that unbelievers forfeit eternal salvation. But why should we accept Gutmann's a priori claim that such beliefs are inherently disrespectful and intolerant? ${ }^{135}$ Many rationalists think religious traditionalists are superstitious, unreasonable, authority-dependent people who turn their backs on individual fulfillment and social justice. ${ }^{136}$ Yet, far from treating this hostility as disrespectful and intolerant, Gutmann herself relies on inaccurate stereotypes of religious traditionalism. ${ }^{137}$

for a full integration of religion, law and politics. (They seldom claim that churches as such should have an influence on the state, and generally reject state interference with religion and promotion of doctrine.)" John $\mathrm{H}$. Garvey, Introduction to Fundamentalism and Politics, in Martin E. Marty and R. Scott Appleby, eds, 3 Fundamentalisms and the State $26 \mathrm{n} 1$ (Chicago 1993). This is tantamount to saying that in practice (and no doubt as a theological matter in many congregations) Christian fundamentalists adhere to an account of "free faith" such as the one Rawls implicitly uses as a criterion to sort out reasonable from unreasonable religious views. See Rawls, Political Liberalism at $\mathbf{1 7 0}$ (cited in note 9).

${ }^{235}$ Rousseau notoriously asserted that a person who thinks I am damned cannot peacefully and tolerantly coexist with me in civil society. See, for example, Jean-Jacques Rousseau, Emile or On Education 257 (Basic Books 1979) (Allan Bloom, trans) (The dogma that "[y]ou must believe in God to be saved" is "the principle of sanguinary intolerance."). But that inference, whatever its force in the context of eighteenth-century, predemocratic Europe, seems as empirically false today as Locke's parallel claim that liberal commitments "can have no hold upon an atheist." John Locke, A Letter Concerning Toleration, in Maurice Cranston, ed, Locke on Politics, Religion and Education 140 (Collier 1965).

${ }_{136}$ "In elite circles, fundamentalists are generally thought to be ignorant, irrational, emotional, and lacking in independence." Michael W. McConnell, Religion and the Search for a Principled Middle Ground on Abortion, 92 Mich L Rev 1893, 1900 (1994), reviewing Elizabeth Mensch and Alan Freeman, The Politics of Virtue: Is Abortion Debatable? (Duke 1993). Drawing on Mensch and Freeman's account of Protestant fundamentalism, McConnell argues that in reality "fundamentalism is highly rationalistic, individualistic, and distrustful of emotion as a guide to right conduct." Id at 1900. These characterizations are grounded in the theological implications of fundamentalism. It is:

[I]ndividualistic, because no human agent may come between the believer and the Word-thus resulting in a theological egalitarianism-and rationalistic, because the believer must apply the rational faculty of reading and understanding to gain access to the perfect Word of God and must distrust his own emotion and instinct, which are products of a fallen nature.

Id at 1900. For a more general account of the ways in which elite opinion in our culture is frequently disrespectful of religious belief, see Stephen L. Carter, The Culture of Disbelief (BasicBooks 1993).

${ }^{137}$ Consider, for example, Gutmann's claim that traditionalist moral education aims 
Perhaps we should conclude that both traditionalists and rationalists are intolerant, and constrain both camps by evenhandedly counteracting parental educational excesses. The obvious remedy would be rationalist schools for religious children, and religious schools for rationalist ones. The evident and pointless divisiveness that system would engender should lead us to reject Gutmann's comprehensive version of toleration in favor of the more limited (and vastly more inclusive) requirement of civic toleration. Once we adopt that standard, it seems undeniable that traditionalists and rationalists alike are overwhelmingly tolerant, law-abiding, and loyal citizens of our liberal democratic society. Our considered judgment, then, should be that (fringe groups aside) parents across the spectrum of beliefs will choose educations consistent with liberalism. ${ }^{138}$ We should give effect to that judgment by denying the state the power to require either rationalist or religious schooling.

\section{Parentalist Theory APPLIED: Minimum EdUCATIONAL STANDARDS, SELECTIVE FUNDING, AND COMPULSORY CURRICULA}

In this Section, I apply the parentalist educational theory developed in Section I to several of the most fundamental issues in contemporary educational theory and practice. Section III.A focuses on the issue of minimum educational standards; Section III.B explores the problem of selective funding; Section III.C offers a parentalist evaluation of two famous curriculum cases

only at what Rawls calls the "morality of authority," and thus leaves children unable to "judge the commands of authorities or their own actions according to whether they live up to the terms of fair social cooperation." Gutmann, Democratic Education at 61 (cited in note 1). Democratic education should aim higher, at Rawls's "morality of association," which stresses "the cooperative moral sentiments - empathy, trust, benevolence, and fairness." Id. At least as applied to traditionalist versions of Protestantism, Judaism, and Catholicism, these charges ignore the resources of religiously grounded reasoning available to persons and communities of faith. Traditional religious education does not seek to deprive children of the capacity to judge the justice or injustice of private or public conduct. It seeks to provide them with religious standards for making precisely those kinds of judgments. As for the "morality of association," suffice it to say that each of the religious traditions in question makes fairness and caring for others central to its conception of the good life.

138 I recognize, of course, that some versions of traditionalism or fundamentalism (like some versions of Enlightenment rationalism) are inherently antiliberal. See David C. Rapoport, Comparing Militant Fundamentalist Movements and Groups, in Martin E. Marty and R. Scott Appleby, eds, 3 Fundamentalisms and the State 429, 457 in 3 (Chicago 1993) (discussing "tiny violent American millenarian communities"). But it would be preposterous to lump the traditionalist mainstream with these outliers. 
(Yoder and Mozert $v$ Hawkins County Board of Education ${ }^{139}$ ), and Section III.D argues that contemporary theorists-who tend to think Yoder wrong and Mozert right-have it backwards.

\section{A. Minimum Educational Standards and the Limits of Consensus}

I have argued that, as a matter of liberal political theory, we should give individual parents the authority to instill their conception of the good in their children, while forbidding the state from mandating that all children be schooled in its conception of the good. The arguments supporting this proposition apply whether a state-mandated conception of the good is arrived at through ordinary democratic politics or (à la Gutmann) offered as a constitutional constraint on ordinary democratic politics. The question to which I now turn is whether and in what ways the liberal state may legitimately intervene for a narrower purpose-to ensure that children receive an education satisfying minimum standards of competence and civic virtue. Is there, in other words, a minimalist understanding of liberal education on which reasonable people would reach consensus?

William Galston's views on liberal education provide an ideal starting point. As against Gutmann and others, Galston argues (as have I) that the liberal state will "betray its own deepest and most defensible principles" if it seeks to "prescribe-as valid for, and binding on, all-a single debatable conception of how human beings should lead their lives." 140 Nevertheless, Galston contends that liberal societies may legitimately use state power to promote thinner and more widely shared understandings of civic excellence and freedom. ${ }^{141} \mathrm{He}$ endorses two general norms that the state may intervene in various ways to enforce. The first is one of "normal development," which includes physical health and "the acquisition of basic linguistic and social skills." 142 The second is "the child's acquisition of a basic civic education-the beliefs and habits that support the polity and enable individuals to

139827 F2d 1058 (6th Cir 1987).

140 Galston, Liberal Purposes at 256 (cited in note 12). For a similar view, see Longstaff, $23 \mathrm{~J}$ Phil Educ at 99 (cited in note 124) ("[A]ny democratic government that seeks to impose a substantively compulsory [educational] framework actually contravenes the democratic principle guaranteeing that the fundamental grounds for consent be unconstrained.").

${ }^{141}$ See Galston, Liberal Purposes at 256 (cited in note 12).

142 Id at 252. 
function competently in public affairs." 143 The norm of basic civic education entitles the state to insist that children be taught to obey the law, to provide for themselves as adults, and to develop "the minimal conditions of reasonable public judgment."144

The proposition that liberal states may legitimately take steps to ensure the child's normal human development seems plainly correct. Surely a consensus exists in our society that a way of life is unreasonable if it denies that health, speech, or reason are human goods under ordinary circumstances. ${ }^{145}$ The proposition that liberal states may legitimately promote allegiance to the core values and institutions on which they depend likewise seems unobjectionable. Liberal regimes must have the power to take reasonably necessary steps to ensure their own survival, and a liberal state devoid of loyal, law-abiding citizens is unlikely to remain liberal for very long.

So far, so good. Galston's assumption that we can and should translate an abstract liberal consensus in favor of these minimum educational ends into legally enforceable standards for implementing them, however, is far more problematic. It ought to be easier to specify what constitutes decent nutrition than what constitutes a decent basic education. Yet although states intervene to protect children from parents who grossly malnourish them, we leave daily authority over the child's diet in parental hands. The implicit judgments such practices reflect ought to give us pause, especially when we shift from health and "the 3Rs" to Galston's norm of "basic civic education."

Consider Galston's assertion that every liberal citizen should possess "the developed capacity to engage in public discourse and to test public policies against our deeper convictions." ${ }^{146}$ This formulation adroitly captures the liberal end of civic deliberation without mandating the values or methods whereby children are to judge public policies. But while few would deny that liberal citizens should be able to evaluate public policy in light of their own considered values, this abstract consensus will inevitably dissolve when it comes to specifying a legally enforceable conception of that goal. If legislation remains at a high level of generality (for example, requiring secondary schools to teach a course on public policy) the consensus may survive, but the effects of such 
laws will be modest at best. If, on the other hand, the state attempts to specify the concepts and techniques that are to structure policy analysis, the result will be to impose one vision of "the right" on substantial numbers of dissenting parents and their children.

This quandary is ultimately traceable to what Rawls has called "the fact of reasonable pluralism": given that we adhere to "reasonable though incompatible [comprehensive] doctrines," 147 our agreements about even basic civic virtues will often prove ineradicably incomplete. ${ }^{148}$ Galston tries to sidestep the problem by writing as if the consensus in favor of the minimal liberal ends he identifies necessarily legitimizes all forms of state intervention to secure them. That cannot be right, both because the consensus is incomplete and because the majority cannot be the sole judge of what is reasonably necessary to accomplish these minimum liberal ends. From the standpoint of liberal pluralism, there is a world of difference between a law that requires parents to teach their children the 3Rs and basic civic education-while leaving parents the freedom to decide how to define and achieve these goals-and one that requires all educations to promote these ends both as the majority conceives of them and in the manner the majority thinks best. The former law is legitimate because it does not outrun the general liberal consensus that these are necessary educational ends. The latter is problematic because it uses state power to impose the majority's version of these ends on parents who accept those ends but hold reasonable, alternative conceptions of them. Problematic, not necessarily illegitimate: if the conflict does not implicate the parents' deepseated values, we might think that the majority should prevail so long as its conception of these ends is reasonable. But if the conflict might significantly undermine the ability of dissenting parents to educate their children in accord with their understanding of the good and the right, the majority must yield unless the parents' views can be shown to be unreasonable. ${ }^{149}$

147 Rawls, Political Liberalism at xvii-xviii (cited in note 9).

148 I do not claim that this will always be the case. The "overlapping consensus" for which Rawls hopes to lay the framework in Political Liberalism at 133-72 (cited in note 9), may sometimes support an enforceable educational norm. See id at 199. But in the context of education I suggest that this will be the exception, not the rule, because we cannot reasonably ask parents, in educating their children, to put aside or "bracket" their comprehensive views.

${ }_{149}$ The formulations in the text are provisional attempts to draw the line at which the ordinary presumption in favor of democratic legislation yields to the counterpresumption in favor of parental authority. The simplest rule would be that parents prevail in all value 
Examples may help clarify my position. Suppose the state requires all seventh graders to take a year-long course in American history. Some parents may be convinced that such a course should come later in the curriculum, either in general or for their child in particular. Their objections, however, are unlikely to involve an important value conflict, and the majority's judgment reasonably promotes the goal of basic civic competence. Assuming the accuracy of this description, the measure is a legitimate one. ${ }^{150}$

Now suppose that the state requires a course in gender equality and that it mandates the use of specific texts and the adoption of a mainstream feminist viewpoint. No doubt we should discount the opposition of some parents on the grounds that it stems from unreasonable views calling for the oppression and subordination of women. But there are many other parents whose traditions teach that women and men should, in general, play different roles and occupy different stations in life. Assuming I am right in thinking that these views-consistent as they are with basic civil rights and citizenship for women-cannot be shown to be unreasonable in liberal terms, ${ }^{151}$ the application of this state law to them violates the liberal pluralist norm. ${ }^{152}$

\section{B. Selective Funding as Indirect Coercion of Parental Educators}

The analysis in Section III.A is, in many respects, consistent with our actual educational practices. The state laws requiring that children be taught particular subjects generally avoid the danger of specifying how and from what viewpoint the curriculum shall be taught. Moreover, parents have the undoubted right under Pierce to withhold their children from our democratically controlled public schools, ${ }^{153}$ whether the clash between their values and those of the schools is fundamental, instrumental, or some combination of the two. In recent years, many states also

conflicts, no matter how minor, unless their views can be shown to be unreasonable. I have tentatively grafted a de minimis exception for minor conflicts onto that rule.

150 A more troubling situation would be present if in the parents' judgment the child would suffer substantial harm from adhering to the standard curriculum. A judgment of that kind may well reflect a value-laden difference between the parents and the majority.

131 Gutmann would again condemn such views as unreasonable, although she offers no convincing argument for doing so. See Gutmann, Democratic Education at 40-41 (cited in note 1) (A democratic theory of education requires schools to challenge "the claim that a woman's place is in the home.").

${ }^{132}$ The same analysis would apply to a statute requiring that all children be taught the superiority of a gender-based division of labor along traditionalist lines.

263 US at 535 . 
have replaced laws severely curtailing home schooling with statutes bringing this option within the reach of more of the families who might wish to consider it. ${ }^{154}$

Nevertheless, in several other respects the conception of parental educational authority I have outlined calls our existing practices into serious question. By far the most important of these is the problem of "selective funding." In every state, the public schools are supported by tax-financed subsidies that parents forfeit if they send their children to private schools or educate them at home. ${ }^{155}$ The result is a decentralized system in which the voices and values of majority parents are amplified by public funds unavailable to dissenting parents. The extent of the resulting burden on minority parents depends, of course, on their financial circumstances, their access to communities of like-minded people, the magnitude of the selective funding funneled to the public schools, and the depth of the conflict between their values and those propounded in the public schools. ${ }^{156}$ Clearly, however,

154 See Patricia M. Lines, Private Education Alternatives and State Regulation, $12 \mathrm{~J} \mathrm{I}$ \& Educ 189, 194-97 (1983) (comparing requirements of various states); Donal M. Sacken, Regulating Nonpublic Education: A Search for Just Law and Policy, 96 Am J Educ 394, 396-98 (1988) (discussing various trends in state requirements). As of 1988, however, six states still required parents to become certified teachers in order to school their children at home. Id at 397.

${ }^{155}$ To be sure, private schools receive some forms of public support. Indeed, one defender of selective funding for public schools describes our existing system as one in which states give "myriad subsidies" to private schools. James S. Liebman, Voice, Not Choice, 101 Yale L J 259, 300 (1991). But this characterization is misleading. Liebman does provide examples of state-created subsidies for transportation, textbook loans, remedial programs for private-school students, and reimbursement for the costs of stateimposed examinations, and singles out "exemption from property, sales, payroll, and other taxes" as the most important benefit state and federal governments give to private schools. Id at 301. But (1) transportation and remedial programs are often provided by the public-school establishment to private-school students, so we might see these not as subsidies to private education but as partial unbundling of public educational benefits; (2) textbook loans are an indirect way of asserting control over the private-school curriculum, so while there is a subsidy there is also an additional cost; (3) reimbursement for statecompelled examinations is a funded mandate, not a subsidy to private education; and (4) public schools enjoy the same (or broader) tax exemptions that private schools do, along with free textbooks and all the rest. So while Liebman's description is a useful reminder that the subsidies to private primary education are substantial, the selective subsidies to public schools dwarf them.

158 The fact that Catholic and other religious schools educate students from across the income spectrum, see James S. Coleman, Thomas Hoffer, and Sally Kilgore, High School Achievement: Public, Catholic and Private Schools Compared 15-64 (Basic Books 1982), shows that it is a bit too simple to say that ours is "a system that prescribes majority control of education decisions for all but the wealthy." Arons, Compelling Belief at 16 (cited in note 27). The question of just how high are the barriers to private education deserves a more discriminating analysis than I can give it here. But it seems tolerably clear that Arons's generalization is basically correct if we include social capital (such as mem- 
millions of families have no real option but to accept schooling at the hands of agents of the state; millions of others must make special sacrifices to provide their children with an education that reflects their values. ${ }^{157}$

From the perspective I have proposed, the question is whether this pressure on parents to school their children in accord with the majority's values should be seen as an illegitimate interference with parental authority or a justifiable byproduct of the majority's desire to achieve the type of liberal goals on which Galston relies. Selective funding does not, it is true, violate liberal neutrality in the directly coercive manner of a mandate that all schools teach particular subjects in line with particular values and methods. Conversely, however, selective funding involves much more than a mere attempt by the majority to promote its values by identifying them as those of the majority. That aspiration would be fully satisfied by a system of democratically controlled public schools that promoted the majority's conceptions of basic skills and civic education, while competing for public subsidies on even terms with private schools. Perhaps such a dual (but evenhandedly financed) system would differ little from an entirely private voucher system in which both majority and minority parents could choose schools congenial to their values. But that is precisely why we should worry that selective funding represents an attempt by the majority to back its own values with the coercive taxing power of the state. ${ }^{158}$

Because he affirms both the liberal state's legitimate stake in promoting basic civic virtues and its obligation to refrain from coercively promoting any particular conception of the good, one would expect Galston to see selective funding as posing a hard theoretical problem. Yet it is an issue he never directly confronts. $\mathrm{He}$ argues that the state "may use public instrumentalities, in-

bership in a religious community that can support a parochial school) in what is meant by "wealth."

157 See Liebman, 101 Yale $L \mathrm{~J}$ at 285 (cited in note 155) (conceding that parents considering private education face a "stiff penalty").

15s The extent of the pressure created by selective funding is a function not only of the price of alternative education, but also of the magnitude of the value conflicts between the majority and dissenting parents. In states or school districts where the majority is content to teach "thin" values, it might be more accurate to say that the public schools fail to reinforce, but do not significantly subvert, the values of dissenting parents. Very often, however, those who control the public school curriculum are intent on promoting values to which some parents are deeply opposed. See generally Arons, Compelling Belief (cited in note 27). See also id at 15 ("From ideological, political, and religious crusaders to racial, moral and sexual objectors, the number of people fighting with each other over what the schools should, or should not, teach has increased dramatically in the last five years."). 
cluding the system of education, to promote the attainment by all children of the basic requisites of citizenship." 159 The state thus "has a right" to promote the core civic education either directly through public schools, or indirectly through regulation of private schools. ${ }^{160}$

But if the state may not require private schools to teach its preferred conception of civic virtue, why may it require parents to pay heavily for the privilege of teaching their children any conception of civic virtue (however reasonable) other than the state's? Perhaps this indirect coercion would be justifiable if we could say that liberal states depend not only on widespread possession of civic virtues such as law-abidingness, but on a consensus in favor of a particular conception of each of those virtues. That assertion, however, seems untenable. A liberal society can flourish without resorting to coerced consensus so long as its citizens' diverse conceptions of liberal virtues contain substantial common ground or "overlap."161 Precisely because those diverse conceptions are rooted in different comprehensive views, however, the state cannot simply abstract the common ground and require all educations to incorporate it.

Moreover, because selective funding dramatically increases the rewards of capturing control of the public school curriculum, it inevitably incites divisive efforts to impose values outside the civic core. As Brian Crittenden (like Galston, a defender of public civic education) concedes, even if common schools could in theory "attain the required level of neutrality in relation to different ways of life," in fact "the common school is far from neutral." In America, as in Crittenden's Australia, the public school curriculum has steadily expanded to include subjects "whose scope clearly runs beyond the defence of the basic social values," and "courses are often explicitly designed to promote a particular set of beliefs and values that are, in fact, contested in the society." ${ }^{\prime 163}$ Any suggestion that selective funding is justifiable because the public school curriculum typically instills a set of civic

159 Galston, Liberal Purposes at 254-55 (cited in note 12).

160 Id at 255.

161 See generally Rawls, Political Liberalism at 134-72 (cited in note 9). Rawls explains the "idea of overlapping consensus" as the means by which "the well-ordered democratic society of justice as fairness may establish and preserve unity and stability given the reasonable pluralism characteristic of it." Id at 133-34.

${ }_{162}$ Crittenden, Parents, the State and the Right to Educate at 124 (cited in note 1).

163 Id at 124. 
values on which virtually everyone agrees is consequently untenable.

Some will argue that this analysis must be wrong because it would effectively prohibit states from establishing a system of public schools. That rejoinder, however, presupposes that democratically controlled schools only count as "public" or "common" schools if they have an exclusive claim on the public's willingness to finance children's formal education. As a glance at the many liberal societies that extend public subsidies to private schools confirms, this presupposition is indefensible: a robust state system can and does coexist with taxpayer-financed private schools in nations such as Australia, France, and Holland. ${ }^{164}$ It is thus quite wrong to treat selective funding as an essential feature of public schools.

Nor does the need for liberal civic education establish the necessity or desirability of state-run schools. "There is no a priori reason to think that the state must own and operate the means of production just because it has a substantive interest in the issue at hand."165 Galston never explains why public operation of schools is preferable to a simple statutory command requiring all schools to teach basic civic education without restricting their freedom to adopt diverse reasonable conceptions of that education. The available evidence indicates that private and religious schools do at least as well as public schools on all three dimensions of Galston's core civic education-basic social morality, key liberal values, and acquisition of basic skills and knowledge. ${ }^{166}$ Indeed, public schooling may be less likely to preserve and extend our common civic ground than the alternative strategy of giving parents of diverse ways and faiths greater freedom to provide their children with the kind of civic education they think best. ${ }^{167}$ Were it not for their monopoly on public finance, howev-

184 See generally Department of Education, Choice of Schools in Six Nations (US GPO 1989) (examining school choice in France, the Netherlands, Belgium, Britain, Canada, and West Germany).

${ }^{165}$ Dennis P. Doyle, The Storm before the Lull: The Future of Private Schooling in America, in John H. Bunzel, ed, Challenge to American Schools: The Case for Standards and Values 147, 158 (Oxford 1985).

${ }^{166}$ See Coleman, Hoffer, and Kilgore, High School Achievement at 122-78 (cited in note 156) (using test scores and other data to compare various public and private school systems); Andrew M. Greeley, Catholic High Schools and Minority Students 54-56 (Transaction 1982) (comparing gender-role attitudes of students at public and parochial schools); Andrew M. Greeley and Peter H. Rossi, The Education of Catholic Americans 153-55 (Aldine 1966) (comparing various social attitudes between students at public and parochial schools).

${ }_{167}$ See McConnell, 1991 U Chi Legal F at 151 (cited in note 33) (arguing that 
er, the effectiveness of public schools in promoting liberal citizenship would raise only prudential issues. Selective funding, by contrast, raises issues of legitimacy far more troubling than even theorists as committed to liberal pluralism as Galston have yet acknowledged. ${ }^{168}$

C. Compulsory Curriculum Requirements: The Examples of Yoder and Mozert

Analytically, we can distinguish three main forms of coercive state intervention in primary education: compulsory public schooling, mandatory curriculum requirements, and selective funding. I have argued that liberal pluralism points toward a broad conception of parental educational rights that is plainly inconsistent with compulsory public schooling and at least prima facie inconsistent with selective funding as well. Mandatory curriculum requirements, on this view, are legitimate only if they promote liberal educational ends in ways that are neutral as among competing, reasonable conceptions of those ends. With this standard in mind, I now turn to two education-law cases that have recently attracted considerable attention from liberal political theorists: Wisconsin $v$ Yoder $^{169}$ and Mozert $v$ Hawkins County Board of Education. ${ }^{170}$

In Yoder, the Supreme Court held, on free exercise grounds, that Wisconsin could not require Amish children who had already completed eight years of conventional schooling to attend a conventional public or private high school until age sixteen. ${ }^{171}$ In Mozert, the Sixth Circuit held that Tennessee need not accommodate Christian fundamentalist parents who enrolled their children in the public schools but refused, for religious reasons, to expose them to the public-school "critical reading" curriculum. ${ }^{172}$ Contemporary political theorists have tended either to reject $Y_{o d e r}{ }^{173}$ or to defend it on the narrow grounds that the

\footnotetext{
"pluralistic education might well turn out to be more unifying than common education ever could be").

${ }_{163}$ In Section IV, I argue that selective funding is invalid as a matter of constitutional law, at least when intended to discriminate on the basis of viewpoint.

406 US 205.

$170827 \mathrm{~F} 2 \mathrm{~d} 1058$.

173406 US at 234.

$172827 \mathrm{~F} 2 \mathrm{~d}$ at 1060.

173 See, for example, Gutmann, 105 Ethics at 567-70 (cited in note 1) (rejecting Yoder on the grounds that Amish children are still American citizens and as such, should be educated in accordance with liberal democratic principles).
} 
Amish are essentially a separate people who have largely renounced both the benefits and burdens of citizenship. ${ }^{174}$ By contrast, Mozert has generally been seen as rightly affirming the state's right to insist that certain core liberal values be made part of every child's education. ${ }^{175} \mathrm{I}$ shall argue, to the contrary, that Mozert was wrongly decided and that Yoder is right on grounds that are not restricted to the Amish.

At bottom, Yoder is a compulsory curriculum case. In lieu of conventional high school, the Amish provide their children with a traditional vocational and religious education in the home, on the farm, and in the community. ${ }^{176}$ Wisconsin sought to force them to accept its preferred curriculum for early adolescents by refusing to treat a traditional Amish education as a valid substitute for a conventional one. ${ }^{177}$ The principles for which I have argued plainly forbid the government from employing coercion under these circumstances. Amish parents do not deprive their children of "normal human development" or "basic civic education" in the senses in which there is genuine liberal consensus in support of those norms. Eight years of conventional schooling is sufficient to equip children with basic skills such as reading, writing, and numeracy, and to provide them with basic knowledge about our society, its institutions, and its history. We may presume that two or three years of high school would not only enable Amish children to develop these skills and knowledge more fully but also increase the range of lives and careers that would be within their immediate grasp. ${ }^{178}$ But their parents have the right to choose for them instead an education that will more fully develop the skills and knowledge vital for flourishing

174 See, for example, Macedo, 105 Ethics at 488-90 (cited in note 1) (grudgingly accommodating the Amish "as private persons standing in merely private relations to others"); Jeff Spinner, The Boundaries of Citizenship: Race, Ethnicity, and Nationality in the Liberal State 88 (Johns Hopkins 1994) ("Although the liberal state can encourage its citizens to be self-reflexive and to act autonomously, it cannot force them to do so."). Galston defends Yoder. See Galston, 105 Ethics at 516 (cited in note 13).

175 See, for example, Gutmann, 105 Ethics at 570-72 (cited in note 1); Macedo, 105 Ethics at 483-88 (cited in note 1) (defending Mozert on the grounds that the parents had no right to be accommodated but acknowledging that school officials could and perhaps should accommodate parents voluntarily). But see Nomi Maya Stolzenberg, "He Drew a Circle that Shut Me Out": Assimilation, Indoctrination, and the Paradox of Liberal Education, 106 Harv L Rev 581 (1993) (arguing that Mozert reveals serious problems with the ideal of liberal neutrality).

176 Yoder, 406 US at 210-12.

177 Id at 208-09.

${ }^{178}$ See, for example, id at 244 (Douglas dissenting) ("[T] pianist or an astronaut or an oceanographer. To do so, he will have to break from the Amish tradition."). 
as a member of an Amish community, thereby increasing their opportunities and competences should they adhere to Amish ways. The additional years of formal schooling the state demands would cut deeply into the time available for the traditional Amish education and deprive these children of the opportunity to learn what their parents' way of life has to offer by practicing and living it as novice members of Amish communities. ${ }^{179}$ Thus, the state is illegitimately using its coercive powers to impose the majority's contestable, albeit reasonable, judgment about the necessary ingredients of a good life over the objections of parents whose faith leads them to make a different but likewise reasonable judgment.

At first blush, Mozert, like Yoder, looks like a compulsorycurriculum case. This is certainly how the decision's defenders generally portray it. ${ }^{180}$ In fact, however, Mozert is more accurately described as a selective funding case. ${ }^{181}$ Tennessee does not require private-and particularly not religious-schools to teach the "critical reading" program at issue in Mozert. Quite the contrary, Tennessee law provides that " $[t]$ he state board of education and local boards of education are prohibited from regulating the selection of faculty or textbooks or the establishment of a curriculum in church-related schools." ${ }^{\text {"182 }}$ Consequently, but for selective funding it seems obvious that the Mozert case would never have arisen. Had the fundamentalist Christian parents been eligible to receive the same subsidies available to parents who approved of the "critical reading" curriculum, they could simply have provided their children with appropriate religious schooling.

In what sense, then, can it be said that Tennessee has any vital interest at stake in insisting that every child who attends public school must be taught the "critical reading" curriculum? If the indirectly coercive practice of selective funding should be seen as legitimate at all, its coerciveness should at least be mitigated by a requirement that the public schools offer neutral reasons for refusing to accommodate minority parents who cannot afford

179 This objection would have less force against a narrower requirement that, say, Amish children enroll in a one-year civics course sometime during their adolescence. Gutmann's failure to consider less restrictive alternatives of this kind demonstrates the enormous overbreadth of her claims that a high school education is a prerequisite to good citizenship. See Gutmann, 105 Ethics at 567 (cited in note 1); Gutmann, Democratic Education at $49 \mathrm{n} 6$ (cited in note 1).

${ }_{180}$ See, for example, Macedo, 105 Ethics at 470-71 (cited in note 1).

131 For a definition of "selective funding," see note 18.

182 Tenn Code Ann § 49-50-801(b) (Michie 1990 \& Supp 1995). 
religious schooling. ${ }^{183}$ The only neutral reason given in Mozert was that it would be too disruptive to excuse these fundamentalist children from their classrooms during the normal reading period and to provide them with space for a study hall. ${ }^{184}$ At some point, of course, administrative concerns might become pressing. ${ }^{185}$ But both public schools (in the case of sex education) and private schools (in the case of religious instruction) routinely excuse pupils from instruction their parents find deeply objectionable. ${ }^{186}$ It seems highly unlikely, therefore, that the opt-out remedy posed a genuine practical problem on the facts in Mozert.

\section{Yoder's Critics, Mozert's Defenders: Political Theory Absent Parentalism}

The contrast between the foregoing analysis and the recent discussions of Yoder and Mozert by Galston, Gutmann, and Macedo brings into sharp focus the tendency of most contemporary political theory to undervalue the importance of the parentchild educational relationship for the human flourishing of both parents and children. To differing degrees, each of these liberal theorists inverts the revealed priorities of most people in liberal societies-namely, family first, citizenship second. ${ }^{187}$ Parenting

183 See Hirschoff, $50 \mathrm{~S}$ Cal L Rev at 917 (cited in note 59) ("The financial difficulties of exercising [the private school] option, compounded by the support of public schools through public taxation, make conditioning public school attendance on requirements that could not be imposed in private schools questionable.").

${ }^{184}$ See Mozert, 827 F2d at 1063. See also id at 1071 (Kennedy concurring).

185 See Hirschoff, $50 \mathrm{~S}$ Cal L Rev at 941 (cited in note 59) ("Excusal could significantly impair administrative efficiency beyond simply increasing costs ... thus justifying not excusing the child."). For an alternative method of accommodation that neatly avoids potential administrative complications, see Michael A. Rebell, Values Inculcation and the Schools: The Need for a New Pierce Compromise, in Neal E. Devins, ed, Public Values, Private Schools 37, 52-53 (Falmer 1989) (proposing private school vouchers for "religious values dissenters" as a solution to the conflict in Mozert).

${ }^{185}$ See George W. Dent, Jr., Religious Children, Secular Schools, 61 S Cal L Rev 863, 924, n 337 (1988) (listing examples of schools excusing children from reading offensive books); Fernand N. Dutile, Sex, Schools and the Law 56 \& n 124 (Thomas 1986) (listing some of the jurisdictions excusing children from sex education classes).

${ }^{187}$ Gutmann's treatment is at times unusually sensitive to the paramount importance of parenting for most individuals. For example, she writes that "an essential part of our good life is imparting an understanding of our values to our children." Gutmann, Democratic Education at 26 (cited in note 1). But this observation never causes her to question the enormous weight she places on citizenship and public life, which is plainly at odds with the way most ordinary, reasonable people pursue the good life. As a result, she ends up treating parenting primarily as the mere result of "a strong human impulse: the desire to pass some of their particular prejudices on to their children." Id at 34. 
is not merely a worthwhile occupation in which a good many liberal citizens happen to engage when they are not busy participating in public deliberations. For the millions of parents who place their families at the center of their lives, the project of educating their children is the cornerstone of their own individuality. We tend to forget the gloss Tocqueville placed on "individualism" when he defined it as the "calm and considered feeling which disposes each citizen to isolate himself from the mass of his fellows and withdraw into the circle of family and friends; with this little society formed to his taste, he gladly leaves the greater society to look after itself."188 To respect and promote this individualism has long been one of liberalism's key commitments to human beings. It is also the most reliable and least dangerous means of securing human beings' commitments to liberalism.

Even Galston, whose conviction that healthy families are an important public policy goal is well known, gives insufficient weight to these reasons for respecting the educational authority of parents. ${ }^{189}$ In his recent defense of Yoder, Galston makes the case for "wide parental rights, limited only by compelling state interests," but he does so solely in terms of liberalism's commitment to toleration and diversity. ${ }^{190}$ Much as I agree with Galston's understanding of toleration, ${ }^{191} I$ think this strategy a mistake. Liberalism's greatest attraction is its success at enabling persons to satisfy their basic human needs. History teaches that conscious familial reproduction, not Gutmann's conscious social reproduction, is a basic human need for most people in

188 Alexis de Tocqueville, Democracy in America 477 (Harper \& Row 1966) (J.P. Mayer and Max Lerner, eds) (George Lawrence, trans).

${ }_{189}$ See Galston, Liberal Purposes at 285 (cited in note 12) (arguing that "the intact two-parent family is best suited to th[e] task" of raising children "as law-abiding and independent members of their community"). Galston's personal commitment to parenting led him to resign from his position as a domestic policy advisor to President Clinton in order to spend more time with his son. See Sue Shellenbarger, Work \& Family: Bill Galston Tells the President: My Son Needs Me More, Wall St J B1, B1 (June 21, 1995).

190 Galston, 105 Ethics at 529 (cited in note 13) (arguing for and outlining the structure of a "Diversity State"). In Liberal Purposes, Galston does argue that liberal societies need to be able to rely on families to develop independence and other liberal virtues in children. Galston, Liberal Purposes at 222 (cited in note 12). His emphasis, however, is primarily on why it is in the state's interest to promote intact families, rather than on why the liberal state is obliged to protect the family as an autonomous realm of human flourishing. Id.

${ }^{191}$ See, for example, Galston, 105 Ethics at 528 (cited in note 13) ("Toleration means ... the principled refusal to use coercive state instruments to impose one's own views on others, the commitment to competition through recruitment and persuasion alone."). 
most societies. Thus, as Locke understood, a society in which parents place "[t]he well educating of their children"192 at the center of their self-understanding is not merely tolerable or edifyingly diverse-it is in large measure what liberalism is for. ${ }^{193}$

Because he proceeds instead by balancing toleration against citizenship, Galston must place major qualifications on his defense of Yoder. He wants us to tolerate the Amish, but he also wants "a vigorous system of civic education that teaches tolerance... and helps equip individuals with the virtues and competences they will need to perform as members of a liberal economy, society, and polity."194 Thus, he believes Yoder was correctly decided only because he also believes that "the facts of Amish life do not appear to warrant [the] conclusion" that "a completed high school education [is] a precondition for full and effective citizenship."195

But why should "full and effective citizenship," or anything like it, ${ }^{196}$ be the test? Beyond insisting on the necessary minimum civic competences on which there is true consensus, why should the liberal state have the power to demand that children be prepared to live active, highly participatory public lives? Liberalism rightly allows adults to decide how much of their lives to invest in being citizens, thereby recognizing that citizenship is but one-and, for most of us, emphatically not the most important-sphere of life. Since, then, parents can reasonably choose for themselves a private life that places little emphasis on citizenship, while honoring the legal obligations of citizens, it is not unreasonable for them to teach their children to hold the same values and adopt the same priorities.

Stephen Macedo rightly criticizes comprehensive liberals for adopting "deeply partisan and not easily defended" ideals, and situates his provocative analysis of Yoder and Mozert squarely within the more tolerant paradigm of Rawlsian political liberalism. ${ }^{197}$ But Macedo fails to deliver on his promise that his anal-

102 John Locke, Epistle Dedicatory to Some Thoughts Concerning Education, in James L. Axtell, ed, The Educational Writings of John Locke 112 (Cambridge 1968).

${ }^{193}$ See Tarcov, Locke's Education for Liberty at 209 (cited in note 59).

194 Galston, 105 Ethics at 528 (cited in note 13).

195 Id at $528 \mathrm{n} 29$.

185 I have in mind, for example, the Rawlsian standard that children be educated "to be fully cooperating members of society," Rawls, Political Liberalism at 199-200 (cited in note 9), which Amy Gutmann takes to be common ground for political liberals and comprehensive liberals. See Gutmann, 105 Ethics at 567-68 (cited in note 1).

197 Macedo, 105 Ethics at 473 (cited in note 1). 
ysis will rest "on grounds widely acceptable to reasonable people-and not only to those who share our particular view of the whole truth." ${ }^{\text {"198 }} \mathrm{He}$ insists that liberal states must have the authority to engage in "reasonable efforts to inculcate core liberal values." Ung Uness "core liberal values" includes all reasonable conceptions of those values, however, this formulation implies that the majority can use coercive state power so long as it reasonably believes doing so is necessary to foster its own conception. Unfortunately, Macedo seems to embrace that implication-or, to put it another way, his criterion for what counts as a reasonable understanding of liberalism turns out to be unjustifiably narrow. ${ }^{200}$ Consider the grounds on which Macedo asserts that the Amish are "not in important respects good liberal citizens"-that they regard women as "unequal helpers of men" and do not prepare their children to be "critically reflective citizens." ${ }^{3201}$ This inference is simply wrong: a person can treat women fairly and respectfully, both in private life and in matters of civil right, while believing that women and men are different and even unequal in important ways. And we have already seen that the rationalist ideal of critical reflection is not a prerequisite for good liberal citizenship.

Ironically, as Gutmann implies, almost everyone who fails her comprehensive-liberal standards of good citizenship would also fail Macedo's political-liberal standards. ${ }^{202}$ Perhaps, then, most comprehensive liberals and most political liberals would in fact agree on a set of core liberal values to which they wish every citizen would subscribe. If the idea of a consensus among reasonable people is to be taken seriously, however, the pollsters must knock at the doors of other liberals too: classical liberals, limitedgovernment liberals, libertarians, prudential liberals, and so on. Once we have consulted everyone who can fairly claim to be

198 Id.

199 Id at 485 (arguing that the liberal state should not accommodate the fundamentalist parents of Mozert).

${ }_{200}$ In my view, Macedo's position is not compelled by Rawls's own conception of political liberalism. The brief discussion of civic education in Rawls's Political Liberalism, while plainly written with Yoder in mind, leaves it unclear how he would in fact judge traditional Amish education. See Rawls, Political Liberalism at 199-200 (cited in note 9) (describing the problem of educating the children of "religious sects [that] oppose the culture of the modern world and wish to lead their common life apart from its unwanted influences").

201 Macedo, 105 Ethics at 488 (cited in note 1). I assume here that the Amish accept the basic civil rights of women while giving them less authority than men within their families and communities.

${ }^{202}$ Gutmann, 105 Ethics at 564-65 (cited in note 1). 
liberal, the core liberal values Macedo defends turn out to be just another debatable conception of liberal citizenship and society.

The Amish, therefore, stand in no need of the "grudging tolerance" for separatists Macedo would use to justify Yoder. ${ }^{203}$ Conversely, Macedo is wrong to rest his approval of Mozert on his judgment that, unlike the Amish (who are "no threat to the larger society" ${ }^{\text {204 }}$ ), the Christian fundamentalists in Mozert "are far more numerous and powerful and are often highly politicized and hostile to at least some liberal values. ${ }^{205}$ If this claim means anything more than that Christian fundamentalists typically refuse to put aside their religious beliefs when they engage in political deliberation and activity, ${ }^{206}$ then Macedo has utterly failed to document it. His characterization of Christian fundamentalists thus appears to rest on the untenable view that the only reasonable comprehensive views are those of political liberals. ${ }^{207}$

The second flaw in Macedo's analysis of Mozert is his highly deferential attitude toward the "critical reading" program on which the state insisted. After conceding doubts about the program's efficacy in promoting the core liberal value of toleration, Macedo argues that, rather than resting our judgments on slippery empirical issues of this kind, we should simply ask whether the program is "a reasonable effort to familiarize students with diversity and teach toleration."208

This test wrongly gives the benefit of "reasonableness" to the coercing party rather than the one coerced: we should instead ask whether the parents' religious objection to the program demonstrates that their views on toleration amount to a wholesale, unreasonable repudiation of that liberal value. If not, their objection should stand as a reasonable attempt to shield their children from the majority's efforts to inculcate a competing conception of toleration that clashes with their religious beliefs.

${ }^{203}$ Macedo, 105 Ethics at 489 (cited in note 1), quoting Spinner, Boundaries of Citizenship at 103 (cited in note 174).

204 Macedo, 105 Ethics at 488 (cited in note 1).

205 Id at 472.

${ }^{206}$ See id at 478 (arguing that totalistic faiths resist political liberalism's requirement that citizens "bracket" the truth of their comprehensive views when engaged in political dialogue with others).

${ }^{207}$ For accounts of why many religious people, not only fundamentalists, steadfastly reject demands that they bracket their comprehensive views for political purposes, see generally Richard John Neuhaus, The Naked Public Square: Religion and Democracy in America (Eerdmans 1984); Carter, Culture of Disbelief at 3-101 (cited in note 136).

208 Macedo, 105 Ethics at 485 (cited in note 1). 
Interestingly, Amy Gutmann argues that the fundamentalist parents in Mozert fail even under a standard in which the parents win if both their views and the state's are reasonable: "A civic education that satisfies the Mozert parents' objections ... would interfere with teaching the virtues and skills of liberal democratic citizenship on any reasonable understanding of what liberal democratic citizenship entails." ${ }^{209}$ As proof of this, Gutmann cites the Mozert parents' religious belief that their children should not be exposed to "knowledge about other ways of life unless the exposure is accompanied by a statement that their way of life is true and all the others are false and therefore inferior." "10 This demand, she implies, would make it impossible for schools to teach the Mozert children "respect for people who pursue ways of life that diverge from those of their parents."211 But where is her evidence for this crucial empirical assertion? One can easily imagine a Christian fundamentalist school in which the teacher routinely prefaces discussions of other ways of life with a statement that they are false and erroneous insofar as they deviate from Biblical truth. One can imagine just as easily that children educated in such a school will learn to understand and respect the persons who pursue these more-or-less false and sinful ways of life. ${ }^{212}$

The reason Gutmann arrives at a different judgment, I suggest, is that she thinks children should also be taught to "respect" other ways of life. ${ }^{213}$ Appealing as that opinion may be, it is hardly a core, consensus-backed tenet of liberalism in the way that respect for persons is. There is, in short, a reasonable understanding of toleration that is quite compatible with the beliefs of the Mozert parents: toleration as respect for the persons and civil rights of others.

${ }^{209}$ Gutmann, 105 Ethics at 572 (cited in note 1).

210 Id at 571.

211 Id at 572 .

212 Indeed, for generations prior to Vatican II Catholic children were educated along quite similar lines: replace "Biblical truth" with "the true faith as explained by the teaching authority of the Church" and disclaimers of the kind Gutmann attacks were commonplace in Catholic schools until relatively recently. Yet it is plainly not the case that preVatican II Catholics were inferior liberal citizens.

${ }^{213}$ See Gutmann, 105 Ethics at 572 (cited in note 1) (suggesting that schools should help children "distinguish between understanding, respecting, and accepting unfamiliar ways of life not their own"). See also the discussion of Gutmann's conception of toleration in Section II.C. 


\section{Translating Parentalist Theory INTo CONSTITUTIONAL LAW}

The political theory of parental educational rights developed so far may be summarized as follows: so long as they remain parents in good standing, ${ }^{214}$ individuals should enjoy the authority to educate their children in accord with their own conceptions of the good and the right. The liberal state may insist that parents provide their children with an education that will develop the basic skills and competences necessary for normal human development and liberal citizenship. State regulation of education must, however, remain neutral among competing reasonable conceptions of the good life and of liberal virtues. Consequently, provided that parental educational choices are consistent with reasonable conceptions of the good life and of liberal citizenship, the state may not use coercive means to promote the majority's preferred conceptions in the domain of formal schooling. ${ }^{215}$ In sum, the state may not ordinarily ${ }^{216}$ override parental educational choices at home or in school unless those choices are plainly unreasonable. ${ }^{217}$

We come now to the difficult enterprise of translating this political theory of parental educational rights into constitutional theory and law. One cannot mechanically restate as norms of constitutional law conclusions arrived at as a matter of speculative political theory. Whether, and with what qualifications, political theory should influence or determine constitutional law remains a controversial issue. ${ }^{218}$ Nevertheless, although I recog-

214 That is, refrain from abusing or neglecting their children.

${ }^{215}$ Of course, some state regulation of schools involves legitimate goals that are not controversially value laden. Fire safety laws, for example, involve the mundane business of protecting children and teachers from fires.

${ }_{216}$ This qualification allows for situations in which an important public purpose extrinsic to education necessitates interference with parental educational choices. For example, compulsory military service for unemancipated young men would undoubtedly interfere with the educational preferences of many parents, but might be necessary if the nation found itself in a sufficiently protracted war. If the state can override the wishes of adult men who prefer to finish their education rather than fight, it presumably can override the wishes of parents with parallel preferences for their seventeen-year-old son.

${ }^{217}$ I put aside the difficult questions that arise concerning the limits of state regulation of parents who hold unreasonable views. At a minimum, the formulation in text implies that states may override the formal educational choices of such parents. The hard questions concern whether the state may legitimately intervene in the home-educational choices of parents whose views are plainly unreasonable.

${ }^{218}$ See, for example, Robert H. Bork, The Tempting of America: The Political Seduction of the Law 133-260 (Free Press 1990) (arguing that constitutional theory should always be anchored in the original meaning of the Constitution, and that political, ethical, 
nize that a full-blown constitutional analysis would need to deal systematically (as I shall not) with such other considerations as original meaning, history, tradition, and precedent, I shall proceed on what I take to be the conventional assumption that political theory has a legitimate role to play in constitutional interpretation. The constitutional analysis I propose is accordingly provisional and exploratory: its aim is to develop a more coherent theory or set of theories for the kinds of parental educational rights already recognized in the Supreme Court's cases, rather than to establish conclusively that the Constitution in fact creates such rights as against the states. ${ }^{219}$

There are three plausible sources of federal constitutional protection for parental educational authority: substantive due process, free exercise of religion, and freedom of speech and expression. ${ }^{220}$ Pierce and Meyer were decided on substantive due process grounds, and the Supreme Court continues to understand them in those terms. I shall therefore begin by showing how the theoretical case for parental educational authority can be used both to interpret and to justify these substantive due process rulings. Because substantive due process is highly controversial as a technique for protecting individual liberty, however, I go on to consider the free exercise and free speech alternatives.

Under Yoder, parents' religiously grounded educational choices are protected by the Free Exercise Clause. That protection, however, is both vulnerable to the general erosion of free exercise protections s21 $^{22}$ and limited to parental choices that are "rooted in religious belief."222 Freedom of speech may therefore provide the better vehicle for a general theory of parental educational rights.

and philosophical theorizing should play only an interstitial role). James E. Fleming, Constructing the Substantive Constitution, 72 Tex L Rev 211, 217 (1993) (surveying the debate and proposing that constitutional interpretation should rely on "the substantive political theory that best fits and justifies our constitutional document and our underlying constitutional order").

${ }_{219}$ So, for example, I do not reexamine the propriety of the Supreme Court's incorporation of the First Amendment into the Due Process Clause of the Fourteenth Amendment.

220 The Equal Protection Clause should perhaps be added to this list. The free speech theory I shall propose later in this Section certainly has overtones of discriminatory treatment with regard to important parental rights and interests. But speech-related discrimination has generally been dealt with in First Amendment rather than equal protection terms. See Laurence H. Tribe, American Constitutional Law 940-41 (Foundation 2d ed 1988).

${ }_{221}$ See, for example, Employment Division v Smith, 494 US 872, 881-82 (1990) (retracting free exercise protection against neutral laws of general applicability).

222 Yoder, 406 US at 215. 
Under the new paradigm I propose, both the direct speech of parents to their children-and their indirect speech through teachers and schools as their agents-should be categorized as parental educative speech that is entitled to the same high-level protection against content- or viewpoint-based state action that political and religious speech already receive.

\section{A. Substantive Due Process as a Source of Parental Educational Rights}

Substantive due process protection entails some form of "reasonableness" review. But which one? On the principles for which I have argued, it is not enough that state educational regulations be reasonably related to the state's general interests in educating children to be flourishing individuals and good citizens. Government does not act reasonably when it coercively overrules the judgments of dissenting parents as applied to their own children unless the parents' stance is unreasonable in terms of the child's best interest or society's legitimate interest in the child as future citizen. Both the early substantive due process decisions in Pierce and Meyer and the Supreme Court's recent "explication of individual liberty" in Planned Parenthood v Casey ${ }^{223}$ support this demanding version of a "reasonableness" test. Of course, as previously suggested, there is language in other Supreme Court cases emphasizing the paramount importance of the state's educational interests and interpreting Pierce and $\mathrm{Meyer}$ narrowly. ${ }^{224} \mathrm{My}$ thesis here, however, is that the Court's reasoning in Casey points toward a broader interpretation of the principle for which Pierce and Meyer stand, one amply confirmed by the tenor of the opinions in those cases.

\section{Casey.}

The linchpin of the majority opinion in Casey is a striking claim about substantive due process: the "conventional constitutional doctrine that where reasonable people disagree the government can adopt one position or the other ... assumes a state of affairs in which the choice does not intrude upon a protected liberty." 225 This proposition unmistakably implies that government may not coerce the choices individuals make within the 
sphere of protected liberty so long as reasonable people can disagree about which choice is preferable. ${ }^{226}$ As Casey reaffirms, this sphere includes "personal decisions relating to marriage, procreation, contraception, family relationships, child rearing, and education."227

As we saw in Section I, parents' decisions about which values to instill in their child involve "choices central to personal dignity and autonomy"228 for both parents and children. ${ }^{22}$ Educating one's child is also a crucial aspect of "the relationships that develop within the unitary family," relationships the Court has long classified as liberty interests. ${ }^{230}$ Moreover, the affirmative case for state intrusion on the family's "privacy interest in the upbringing and education of children"231 is in general weak because parents have better incentives to make those decisions consistently with their children's best interests than does the state or its agents. ${ }^{232}$ Whether or not the Court would evaluate regulation of education under the "undue burden" test that a decisive plurality of Justices employed to evaluate regulation of abortions in Casey, ${ }^{233}$ then, the general explication of substantive due process that did command a majority in Casey makes clear that the controlling question is whether reasonable persons could disagree over the choice the state would impose on dissenting parents and their children.

${ }^{226}$ I interpret the majority opinion's acknowledgement that states may "act in some degree to further their own legitimate interests in protecting prenatal life," id at 853 , to mean that a woman's decision to have an abortion is under some circumstances a plainly unreasonable choice. That the plurality disagreed with Justices Blackmun and Stevens over the precise extent to which the states may enact abortion-related regulations seems primarily to reflect differences over where to draw the line between persuasion and coercion. See id at 914-17 (Stevens dissenting in part); id at 934-940 (Blackmun dissenting in part). Though the opinions use the language of compelling state interests rather than unreasonableness, it seems fair to say that all of the Justices in the Casey majority believe a state may conclude that it is plainly unreasonable to abort a viable fetus absent some threat to the mother's life or health. See id at 877 (O'Connor, Kennedy, and Souter opinion); id at 914 (Stevens dissenting in part); id at 934 (Blackmun dissenting in part).

227505 US at 851.

${ }_{228}^{22}$ Id.

229 See text accompanying notes 86-88.

${ }^{230}$ Michael H. $v$ Gerald D., 491 US 110, 123 (1989) (plurality opinion). See also id at 141-42 (Brennan dissenting).

${ }^{231}$ Hodgson $v$ Minnesota, 497 US 417, 446 (1990) (plurality opinion).

${ }_{232}$ See Section I.C.

${ }^{233}$ See Jon S. Lerner, Comment, Protecting Home Schooling through the Casey Undue Burden Standard, 62 U Chi L Rev 363 (1995) (exploring this possibility in the context of home schooling regulation). 
2. Pierce and Meyer.

Both Pierce and Meyer are best read as requiring states to show that the parental educational decisions with which their laws coercively interfere are plainly unreasonable. The issue on which these cases turn is not whether state educational regulation is reasonable in the abstract, but whether it "unreasonably interferes with the liberty of parents." 234 The two are emphatically not the same.

In striking down Oregon's compulsory public schooling law, the Pierce Court endorsed precisely the principle for which I have tried to supply a theoretical footing: that "[t]he child is not the mere creature of the State; those who nurture him and direct his destiny have the right, coupled with the high duty, to recognize and prepare him for additional obligations."235 That formulation qualifies the Court's subsequent recognition that states may "reasonably regulate all schools," and may in particular require "that certain studies plainly essential to good citizenship must be taught, and that nothing be taught which is manifestly inimical to the public welfare." ${ }^{236}$ Under Pierce, educational regulation is not reasonable unless what it commands is "plainly essential" and what it forbids is "manifestly inimical." The Oregon measure failed this test because it mandated public schooling in order to dictate the viewpoint and values that would guide every child's formal education. ${ }^{237}$ Because the law thus overrode a wide range of parental decisions that could not be shown to be unreasonable, ${ }^{238}$ the Court condemned it as an illegitimate attempt by the state "to standardize its children." 239

Meyer, which was decided before Pierce but with the Oregon law very much in mind, ${ }^{240}$ likewise turned on the government's

234 Pierce, 268 US at 534.

235 Id at 535.

236 Id at 534.

237 The argument printed on the initiative ballots confirms that Oregon's agenda was comprehensively partisan: "Mix those with prejudices in the public school melting pot for a few years while their minds are plastic, and finally bring out the finished product-a true American." Barbara Bennett Woodhouse, "Who Owns the Child?": Meyer and Pierce and the Child as Property, 33 Wm \& Mary L Rev 995, 1018 (1992), quoting Official Ballot Argument (Affirmative).

${ }^{238}$ See Pierce, 268 US at 534 (describing private schools as "a kind of undertaking not inherently harmful, but long regarded as useful and meritorious").

239 Id at 535.

240 As Barbara Woodhouse has recently shown, although Pierce was decided some two years after Meyer, the Court was well aware of the controversial, newly enacted Oregon universal public schooling law when it struck down the comparatively mild Englishlanguage laws in Meyer. Woodhouse, 33 Wm \& Mary L Rev at 1076-80, 1085-87 (cited in 
inability to establish that the parental educational choices it prohibited were plainly unreasonable. The Court's starting point was "the power of parents to control the education of their own," which it treated as an aspect of protected liberty. ${ }^{241}$ The Court did not deny Justice Holmes's contention that "it is desirable that all the citizens of the United States should speak a common tongue, and therefore that the end aimed at by the statute is a lawful and proper one. ${ }^{1242}$ But there were good reasons to question the needlessly burdensome means chosen to achieve this end. As the Court noted, the English-only laws at issue in Meyer and its companion cases, rather than simply requiring schools to teach English, forbade them to teach foreign languages altogether. ${ }^{243}$ The primary effect of banning foreign-language instruction is surely to impede the learning of foreign languages, not to facilitate the learning of English. Consequently, the Meyer Court viewed the decisive question as whether the ban could be justified on the ground that instruction in foreign languages was "clearly harmful" in itself. ${ }^{244}$ The Court thought not, on the ground that the mere knowledge of a foreign language had "[h]itherto . . . been commonly looked upon as helpful and desirable." ${ }^{45}$ Meyer thus stands for the proposition that states may not pursue legitimate educational ends by means whose primary effect is to override the reasonable educational choices of parents. $^{246}$

\section{Coercion, persuasion, and selective funding.}

Although this is not the place for an extended survey of the lower-court case law dealing with substantive due process challenges to state educational regulation, it is clear that many courts reject the approach I have outlined in favor of a more deferential version of reasonableness review. ${ }^{247}$ The Court's ac-

note 237).

241 Meyer, 262 US at 400-01.

${ }^{242}$ Id at 412 (Holmes dissenting).

${ }^{243}$ Meyer, 262 US at 402.

241 Id at 403 .

245 Id at 400 (discussing knowledge of the German language).

${ }^{246}$ See also Farrington v Tokushige, 273 US 284, 298 (1926) (striking down state regulation of supplemental foreign-language schools that denied parents "reasonable choice and discretion in respect of teachers, curriculum and text-books").

${ }^{247}$ See, for example, Null v Board of Education, 815 F Supp 937, 939 (S D W Va 1993) (describing Pierce rights as involving only "a general liberty interest subject to reasonable state regulation"); Hanson v Cushman, 490 F Supp 109, 112 (W D Mich 1980) (contrasting reasonableness review with "compelling interest" analysis); Jernigan v State, 412 S2d 
knowledgement in Pierce of "the power of the State reasonably to regulate all schools" ${ }^{\text {248 }}$ is all too often construed to require only that regulation bear an arguable relationship to the state's general interests in educating children to be productive individuals and good citizens. ${ }^{249}$ Thus, for example, "lower courts have generally assessed state home schooling regulations under the lowlevel rational basis standard of review."250

Under the interpretation of Pierce I have proposed, by contrast, the essential question would be whether the law's requirements were so clearly in the best interests either of all individual children or of society that dissenting parents could not reasonably object to them. Were that interpretation generally accepted, we would no longer witness decisions such as those upholding state laws requiring private school teachers-and even home schooling parents-to be certified teachers. ${ }^{251}$ Correcting the existing underenforcement of Pierce would thus significantly curtail state oversight of private education in the more aggressively regulatory states.

What is more doubtful is whether even a Pierce revival would sweep broadly enough to place the practice of selectively funding public schools in serious constitutional doubt. Because the discussion of parents' free speech rights in Section IV.C deals with selective funding in some depth, my treatment of it here will be brief. The issue on which I wish to focus concerns Michael McConnell's suggestion that "Pierce and Meyer ... . were predicated on limits to the use of governmental force, even when deployed to promote objectives within the government's legitimate authority. ${ }^{.252}$ Were this true, selective funding of public educa-

1242, 1246 (Ala Crim App 1982) (applying deferential reasonableness review to law requiring home schooling parents to hold public teaching certificates); State $v$ Shaver, 294 NW2d 883, 899 (ND 1980) (applying deferential reasonableness review to compulsory education requirements). See also Blackwelder $v$ Safnauer, 689 F Supp 106, 136 (N D NY 1988) ("The degree of judicial scrutiny to be applied to a governmental action that interferes with the privacy interests recognized in Pierce and Meyer ... is not clear to this court."). Some courts, however, employ a more demanding standard of review. See, for example, Care and Protection of Charles, 399 Mass 324, 504 NE2d 592, 598-600 (1987) (applying a form of heightened scrutiny in home schooling context).

268 US at 534.

219 See Yudof, When Government Speaks at 227-30 (cited in note 19).

250 Lerner, Comment, $62 \mathrm{U} \mathrm{Chi} \mathrm{L}$ Rev at 364 (cited in note 233).

251 See, for example, Fellowship Baptist Church v Benton, 815 F2d 485, 492-95 (8th Cir 1987) (upholding teacher certification requirement as applied to religious schools); People v Bennett, 442 Mich 316, 501 NW2d 106, 111 (1993) (upholding certification requirement as applied to home schooling).

${ }_{232} \mathrm{McC}$ Connell, 104 Harv L Rev at 1035 (cited in note 18). 
tion would not be problematic under Pierce because it involves no direct coercion.

I agree with McConnell that Pierce and Meyer rest on an anticoercion rationale. But in order to arrive at the counterintuitive conclusion that this rationale is limited to coercion understood as force, McConnell also asserts that Pierce and Meyer do not rest on an autonomy rationale. ${ }^{253}$ That claim is difficult to reconcile with the Pierce Court's assertion that our "fundamental theory of liberty" forbids the state to treat the child as its "mere creature" and protects the "liberty of parents ... to direct the upbringing and education of children under their control."254 The more faithful (and sensible) reading of the opinions is that they limit state coercion for the sake of the autonomy of parents and children. In that light, the notion that parents' educational rights are good against only forcible state interference seems quite odd. Suppose Oregon law had provided that children who attended private elementary schools would henceforth be barred from attending any public school or college in the state. Is it plausible that the Pierce Court would have upheld this massive penalty because parents who spurned the public schools faced no threat of jail?

The better view begins with the maxim that government may not do indirectly what it is forbidden to do directly. As Cass Sunstein points out, when the government engages in selective funding it is attaching "strings" to the exercise of constitutional rights, and although this may sometimes be permissible, "the pressure imposed by the strings . . . is constitutionally troublesome." ${ }^{255}$ In the case of selective funding of compulsory education, we have both a background threat of force (parents who reject public schools and fail to obtain an alternative education for their child face criminal penalties) and, more importantly, extremely large and expensive "strings." Sunstein is certainly right that we should consider "the available government justifications;"256 a full Pierce analysis would need to do so. But the pressure selective funding puts on parental educational choice is so severe that we should treat it as "coercive" and require the government's justification to be truly compelling.

${ }^{253}$ See id at 1035-36.

${ }^{254} 268$ US at 534-35. See also Meyer, 262 US at 399 (" $[T]$ he liberty thus guaranteed [by the Due Process Clause] ... [w]ithout doubt [ ] denotes ... the right of the individual . . . to establish a home and bring up children.").

${ }_{255}$ Cass R. Sunstein, The Partial Constitution 303 (Harvard 1993).

256 Id at 301 . 


\section{B. The Free Exercise Clause as a Source of Parental Educational Rights}

Theoretically appealing as the principles declared in Pierce and Meyer are, the fact remains that substantive due process is a particularly controversial way to give them constitutional status. The Court's approving references to Pierce confirm that a core of parental educational rights is here to stay regardless of its constitutional provenance. ${ }^{257}$ Nevertheless, the Constitution makes no mention of the general "theory of liberty" the Court invoked in Pierce. Moreover, the parental educational rights recognized in Pierce are not inherently linked to substantive due process. ${ }^{258}$ For many parents, educating one's child in one's religious tradition is a central aspect of religious practice. It might be better, then, to look to the Free Exercise Clause of the First Amendment as the source of parental constitutional rights.

Yoder illustrates the difference that reliance on an enumerated constitutional right can make. ${ }^{259}$ The Amish parents in Yoder interposed a free exercise defense to Wisconsin's application of its compulsory education laws to their families. ${ }^{260} \mathrm{Be}-$ cause the Supreme Court initially described the state's educational interests in uncritical and inflated terms, ${ }^{261}$ we may infer

257 See, for example, Casey, 505 US at 849; id at 951 (Rehnquist dissenting in part).

253 Barbara Woodhouse argues that the parental constitutional rights recognized in Meyer and Pierce are grounded in (rather than accidentally associated with) Lochner-era economic- and property-based conceptions of substantive due process, and rest on an "emphatically reactionary" theory whose thrust is "to sustain traditional patriarchal structures" and forestall the development of children's rights. Woodhouse, $33 \mathrm{Wm} \&$ Mary $L$ Rev 995, 1084-85, 1112 (cited in note 237). These claims rest on an unpersuasive reading of Pierce and Meyer. Believers in absolute patriarchal authority would of course have seen those decisions as steps in the right direction. But it is a plain non sequitur to leap from this observation to the conclusion that the underlying theory of the opinions was patriarchal in character. Whatever may have been the private views of Justice McReynolds, his opinions for the Court adopt a parental theory, not a patriarchal one. Nothing in either opinion hints either that the Constitution subordinates the parental liberty of mothers to that of fathers or that parents have unlimited power over their children. On the contrary, Pierce and Meyer explicitly preserve the state's authority to enact reasonable educational regulations governing private education. As we have seen, there is room for disagreement over how demanding the criterion of "reasonableness" is in this context. Clearly, however, under Pierce states may place significant limits on, for example, excessive parental force and other modes of coercion.

${ }^{259}$ For a dramatic recent example of this difference, compare People $v$ Bennett, 501 NW2d 106 (Mich 1993) (rejecting a substantive due process challenge to Michigan's teacher certification requirement for home schools), with People $v$ DeJonge, 501 NW2d 127 (Mich 1993) (holding that Michigan's teacher certification requirement for home schools violates the Free Exercise Clause as applied to parents who object to certification on religious grounds).

200406 US at 209.

281 See id at 213 ("Providing public schools ranks at the very apex of the function of a 
that the Court likely would have ruled against the Amish had their claims involved only "the general interest of the parent in the nurture and education of his children."262 But because the parents' defense was religious in nature, the Court did not let the mere existence of these "compelling" state interests preclude a careful evaluation of the law's purposes and effects as applied to the Amish. ${ }^{263}$ The Court then found that the state had failed to show that a traditional Amish education leaves children unprepared to be self-supporting adults or to discharge the duties of citizenship..$^{264}$

Wisconsin, however, also asserted that traditional Amish education jeopardized its interest in ensuring that Amish children have an adequate "opportunity to make an intelligent choice between the Amish way of life and that of the outside world."265 As the Court correctly perceived, to authorize the state to set up this kind of demanding (and one-sided) standard for "intelligent choice" would enable it to "in large measure influence, if not determine, the religious future of the child.2266 The Court denied the state this power, on the ground that Pierce "stands as a charter of the rights of parents to direct the religious upbringing of their children."267

These rights necessarily imply that the state may not seek to win children away from the religious convictions of their parents through coercive means. ${ }^{268}$ Thus, the most important holding in

\footnotetext{
State.").

262 Id at 233 (reading Pierce as holding that when only this "general interest" is at stake, "the State acts 'reasonably' and constitutionally in requiring education to age 16 in some public or private school meeting the standards prescribed by the Staten). This statement leaves open the possibility that the state-prescribed standards for compulsory education might unreasonably interfere with parental educational authority. But it can also be read to mean that state educational standards will be subject to very deferential (if any) review under Pierce. Justice White's concurring opinion in Yoder seems to adopt this latter position. See id at 239 (White concurring) ("[Pierce] lends no support to the contention that parents may replace state educational requirements with their own idiosyncratic views of what knowledge a child needs to be a productive and happy member of society ....").

${ }^{263}$ See Yoder, 406 US at 221.

264 See id at 234.

265 Id at 232.

268 Id.

${ }^{267}$ Id at 233. See also id at 232 ("[T]his case involves the fundamental interest of parents, as contrasted with that of the State, to guide the religious future and education of their children.").

${ }^{263}$ I shall not dwell on Justice Douglas's famous contention that Amish teenagers should decide which kind of education they would receive. See id at 244 (Douglas dissenting). But see Parham v J.R., 442 US 584, 603-04 (1979) ("We cannot assume that the result in Meyer $v$ Nebraska [ ] and Pierce $v$ Society of Sisters [ ] would have been different
} 
Yoder incorporates the idea at the core of Pierce: that parental educational rights trump even legitimate state purposes unless "harm to the physical or mental health of the child or to the public safety, peace, order, or welfare has been demonstrated or may be properly inferred."269 But rather than grounding these parental rights in a free-floating theory of substantive due process, the Yoder Court was able to rely directly on the text of the Free Exercise Clause.

In another way, however, Yoder takes away with one hand what it gives with the other. Section V of the Court's opinion insists that "courts must move with great circumspection in performing the sensitive and delicate task of weighing a State's legitimate social concern when faced with religious claims for exemption from generally applicable educational requirements. ${ }^{270}$ The only reason given for this signal-which at times seems closer to a flashing red light than a yellow one-is that courts "are ill-equipped to determine the 'necessity' of discrete aspects of a State's program of compulsory education."271 That seems a feeble excuse for underenforcement of the Free Exercise Clause. When the government interferes with parents' efforts to guide the religious education of their children, the government should lose if the necessity of its program is not quite clear-that is, easily determinable by the court. On this issue, Yoder departs from the principle for which it stands.

if the children had announced a preference to learn only English or a preference to go to a public, rather than a church, school."). The theoretical arguments of Section I of this Article suggest, however, that we might approach this question by asking whether the children of mainstream parents should be legally empowered to decide whether they should receive an Amish education (or whichever other alternatives are available in their locale) in lieu of a conventional one. I think it clear most parents-including some who think Justice Douglas made a telling point about the dangers of not consulting Amish children-would regard this proposal with consternation. If we would not apply Douglas's solution to our children, what entitles us to apply it to Amish children?

200 Yoder, 406 US at 230. To similar effect, Justice White's concurring opinion suggests that the state's interest in preparing children for adult life is not seriously infringed unless they would be "intellectually stultified or unable to acquire academic skills later." Id at 240 (White concurring). See also Note, Adjudicating What Yoder Left Unresolved: Religious Rights for Minor Children After Danforth and Carey, $126 \mathrm{U} \mathrm{Pa} \mathrm{L} \mathrm{Rev} \mathrm{1135,}$ 1145 (1978) (arguing that under Yoder, "the state may not circumscribe parental discretion in religious matters unless some palpable harm would otherwise befall the child.").

270 Id at 235. Indeed, Yoder's ruling in favor of the Old Order Amish was "so heavily qualified" and "so laden with rhetoric" about the special character of the Amish way of life that "the broad exemption from schooling has never been granted by any other court to any other group." Carter, Culture of Disbelief at 172-73 (cited in note 136).

271 Yoder, 406 US at 235. 
Yet even if the Court were willing to jettison these aspects of Yoder, parental free exercise rights would remain much narrower than the general parental educational rights recognized in Pierce. As Yoder also holds, the Free Exercise Clause encompasses only moral values that are "rooted in religious beliefs."272 One might conceivably argue that fundamental issues of moral values and good citizenship should be seen as "religious" in nature for free exercise purposes. The constitutional text, however, seems to cut the other way, for "religion" seems to refer to matters involving belief in a deity and is thus narrower than, say, "conscience."273 Moreover, because a broader definition of "religion" would greatly expand the scope of the Establishment Clause, the Court might well be forced to reconsider much of its Establishment Clause jurisprudence to boot. ${ }^{274}$ This limit on parental educational rights under the Free Exercise Clause, then, seems here to stay-and, as a matter of constitutional interpretation, probably rightly so.

\section{Freedom of Speech as a Source of Parental Educational Rights}

Neither substantive due process nor the Free Exercise Clause provides an uncontroversial and unrestrictive foundation for parental educational rights. Might freedom of speech and expression do so? In this Section, I argue that parents have a free speech right to communicate their values to their children both directly and through the speech of teachers and schools as their chosen agents. Consequently, state educational regulation that coerces or pressures parents to conform their child's education to the state's preferred values constitutes viewpoint-based interference with parental speech. As such, it is presumptively unconstitutional. ${ }^{275}$

272 Id at 215-16.

${ }^{273}$ See Stanley Ingber, Religion or Ideology: A Needed Clarification of the Religion Clauses, 41 Stan L Rev 233, 249-52 (1989) (surveying the constitutional meaning of "religion").

274 The word "religion" occurs only once in the First Amendment, and consequently it is quite awkward to give it one meaning for purposes of the Free Exercise Clause and another for purposes of the Establishment Clause. See US Const, Amend I ("Congress shall make no law respecting an establishment of religion, or prohibiting the free exercise thereof .....").

${ }^{276}$ See, for example, Rosenberger $v$ Rector and Visitors, 115 S Ct 2510, 2516 (1995) ("Discrimination against speech because of its message is presumed to be unconstitutional."). 
1. Refocusing the free speech inquiry on parental educative speech.

The substantive due process rulings in Pierce and Meyer have tended to obscure the serious free speech problems associated with state regulation of education. Both cases were decided when substantive due process was in its heyday and First Amendment jurisprudence in its infancy. Unsurprisingly, the Court took what was then the road more travelled. The contemporary Court and contemporary scholars have no such excuse. Yet with the notable exception of Stephen Arons, ${ }^{276}$ modern First Amendment scholars have seen no need for a root-andbranch evaluation of our educational practices. Instead of asking whether the key structural features of our educational system are consistent with freedom of speech and expression, both commentators and the Court tend to assume the legitimacy of the existing educational structure, and ask only how freedom of speech for students and teachers can be preserved within it. ${ }^{277}$

276 Arons has long argued that the First Amendment prohibits states from regulating the content of private schooling, or selectively funding public schooling, except where compelling justifications exist. Arons, Compelling Belief at 213 (cited in note 27). His core argument is that freedom of speech and expression necessarily presupposes, and should legally include, freedom in the formation of persons' beliefs and opinions. "The individual ought to control his own education, or where the individual is too young to make an informed and voluntary choice, his parents ought to control it." Arons and Lawrence, 15 Harv CR-CL L Rev at 313 (cited in note 27). The centerpiece of Arons's theory is thus the child's right not to be educated by the state.

The theory of parental educative speech I develop in this Section, by contrast, is primarily an explication of the parents' right to communicate their values to their own children. This is not the occasion for a full-scale comparison of these alternative First Amendment approaches. There are, however, a handful of points worth noting here: (1) these theories need not be mutually exclusive-it is possible, for example, that we should conceive these issues in terms of parental free speech when children are young, but recharacterize them later (say, for mid-adolescents) in terms of the child's right; (2) the theoretical arguments for parental educational authority presented in Section I can be deployed to buttress a crucial (and underdeveloped) step in Arons's theory-the move from recognizing the child's belief-formation right to granting parents the authority to exercise that right on the child's behalf; (3) the two approaches yield similar results in cases where child and parents agree, and even where the child sides with the majority, the two approaches converge insofar as Arons would allow parents to invoke the child's rights against the state despite the child's contrary preference; (4) Arons's more recent writing has emphasized "the idea of education as communication," Arons, 1 Threefold Rev at 12 (cited in note 27), and that approach certainly seems consistent with giving special weight to the communication between parents and children; and (5) last but not least, I acknowledge a large debt to Arons's pioneering work, both for its constitutional analysis and its powerful treatment of the wrenching value conflicts public education can engender for dissenting families.

277 There is a large body of literature the common theme of which is that although the First Amendment allows government to create a system of democratically controlled, 
The First Amendment cases and literature on primary and secondary education consequently center on issues that-while far from unimportant-involve the periphery of our educational practices rather than their core. We have leading cases on what kinds of messages public school students can display on their jackets, what they can say at a school assembly or in the school newspaper, how far a local majority may go in purging the school library of controversial books, and so on. ${ }^{278}$ The really crucial educational issues-compulsory public schooling, home schooling, mandatory curriculum regulation, and selective funding-are treated as within the jurisdiction of substantive due process rather than that of the First Amendment. In turn, as we have seen, the Pierce compromise is often understood to rule out only the most extreme and intrusive forms of state educational intervention in these areas, while leaving the rest to the vagaries of the political process.

If we are to have a coherent and rigorous First Amendment jurisprudence in the realm of education, this particular slate needs to be wiped clean. Given subsequent developments in the jurisprudence of free speech, it makes little sense to read Pierce and Meyer as holding that all "reasonable" regulation of education is ipso facto consistent with the First Amendment. The question ought to be how we should think about compulsory public

value-laden, selectively funded public schools, it significantly constrains the extent to which the government may indoctrinate students or restrict their speech within these schools. See, for example, Stephen E. Gottlieb, In the Name of Patriotism: The Constitutionality of "Bending" History in Public Secondary Schools, 62 NYU L Rev 497, 512-13 (1987); Stanley Ingber, Socialization, Indoctrination, or the "Pall of Orthodoxy": Value Training in the Public Schools, 1987 U III L Rev 15, 78-95 (examining ways to limit public school value inculcation that threatens individual autonomy); Tyll van Geel, The Search for Constitutional Limits on Governmental Authority to Inculcate Youth, 62 Tex L Rev 197, 289-91 (1983) (arguing that "the constitution precludes the implementation of an educational program ... designed to inculcate official values and beliefs"); Yudof, When Government Speaks 213-33 (cited in note 19). If pressed far enough, of course, this reasoning can lead to a shift in perspective similar to the one I propose. Here the leading example is Mary-Michelle Upson Hirschoff's argument that, given selective funding, the First Amendment often requires accommodation of parental objections to aspects of the public school curriculum. See Hirschoff, $50 \mathrm{~S}$ Cal L Rev at 904-41 (cited in note 59).

${ }^{278}$ See Tinker $v$ Des Moines Independent Community School District, 393 US 503, 51314 (1969) (holding that schools may not prevent students from wearing armbands to protest Vietnam War); Bethel School District No 403 v Fraser, 478 US 675, 685-86 (1986) (holding that schools may sanction students for lewd and indecent remarks at a school assembly); Hazelwood School District v Kuhlmeier, 484 US 260, 274 (1988) (holding that high school may censor student newspaper to protect individual privacy and to avoid controversy); Board of Education v Pico, 457 US 853, 872 (1982) (holding that school officials cannot remove library books "simply because they dislike the ideas contained in those books"). 
schooling, curriculum regulation, selective funding, and similar bedrock issues in free speech terms today. ${ }^{279}$

Here the theoretical arguments from parental ideals and incentives presented in Section I come into play. The fundamental proposition those arguments sought to establish is that as a matter of liberal political theory parents should have the right to educate their children in accord with their own values and ideals and free from coercive state interference. As I shall now argue, this right can readily be translated into free speech terms, because the enterprise of educating one's children is above all a matter of parental educative speech. In evaluating state educational regulation in First Amendment terms, therefore, we should often focus on the regulation's impact on the speech of parents, rather than, as the conventional approach would have it, on the speech of students and teachers. Once this is seen, the First Amendment issues take on a new and more pressing character.

2. Defining and protecting direct parental educative speech.

Speech and expression are the ordinary means whereby parents seek to impart values, habits, skills, and knowledge to their children. Consider the daily education of, say, a three-yearold. From reading a story, to identifying objects and colors, to reiterating the rules against biting and fighting, to picking out dinner and treats at the grocery store, to hugs and kisses at bedtime, parental nurturing and educating pervasively consist of speech and other communicative acts directed toward the child. Whether their children are preschoolers, adolescents, or somewhere in between, parents-like all teachers - educate by communicating, most often through language but also through other media such as music, pictures, and gestures. Using "speech" in the broad sense of communication, then, it is plain that parental educative speech plays a predominant role in the education of most children.

What level of protection should parental educative speech receive under the First Amendment? In light of the importance of parental educative speech to the human flourishing of parents and children, a strong case can be made for according this category of speech the same protection we extend to political and reli-

279 I have been helped on this point by Robert Beranek, Constitutional Implications of State Regulation of Private School Curriculum (unpublished manuscript on file with U Chi L Rev). 
gious $^{280}$ speech. Parents whose educational messages to their child express their fundamental values and beliefs are engaged in an activity no less central to the free competition of ideas in the larger society than is value-laden speech among adults. ${ }^{281}$ It is no accident that the good and the right are as central to parental educative speech as to citizens' political speech. And, whatever may be the case under the Free Exercise Clause, in free speech terms it should make no difference whether the values parents express are "rooted in religious belief" or based on conscientious convictions of other kinds. In short, parental educative speech (at least on value-laden matters) should be treated as "core" speech.

3. The forgotten category of indirect parental educative speech.

Parental educative speech is easiest to recognize in those settings-preschool, home schooling, and everyday home life-in which parents themselves educate their children. Parents' status as "speakers" is undeniable when they directly express their educational messages and preferred values to their children. What tends to be overlooked, however, is the fact that parents routinely engage in indirect parental speech as well. Parents who choose a school because its curriculum reflects the knowledge and values they think their child should learn have not ceased to communicate the messages they want the child to hear. They have simply chosen to deliver those messages through the school and its teachers as their educational agents. The traditional understanding of education, in which teachers act in loco parentis, and parents authorize and ratify the classroom lessons their children receive, captures the basic relationship.

Parents are no less "speakers" for First Amendment purposes when they communicate indirectly with their children through the speech of schools, teachers, home tutors, or other educational intermediaries. When a person employs another to speak on his

${ }^{280}$ See Capitol Square Review and Advisory Board v Pinette, 115 S Ct 2440, 2446 (1995) ("[P]rivate religious speech, far from being a First Amendment orphan, is as fully protected under the Free Speech Clause as secular private expression.").

${ }^{281}$ One can imagine particular parentally chosen messages that are so perverse or destructive that other First Amendment analogies (for example, to obscenity) might seem preferable, and in such cases greater deference to state regulation would be appropriate. More generally, First Amendment protection of parental educational speech may need to diverge somewhat from ordinary free speech doctrine, because the risk that children will be conditioned by parental speech to behave in unlawful ways may be greater than the parallel risk for adult audiences. 
or her behalf, the liabilities and privileges that apply to the agent generally apply to the principal as well. If $A$ employs $B$ to spread a defamatory rumor about $\mathrm{C}, \mathrm{A}$ and $\mathrm{B}$ are jointly liable as defamatory speakers. By the same token, a ban on newspaper advertising interferes with the speech of would-be advertisers and newspapers alike. ${ }^{282}$ A court order barring a criminal defendant's lawyer from trying the case in the media interferes with the speech of both attorney and client. ${ }^{283}$ In all these other contexts, the rule is that one may communicate through one's chosen agent without thereby forfeiting the protection of the First Amendment.

The contrary rule-that freedom of speech is limited to persons directly engaging in communicative activities-would penalize indirect modes of speech that individuals presumably regard as more effective or less costly ways to achieve their communicative purposes. (It might also invite government overreaching: What if the criminal defendant's lawyer refused to appeal the trial court's gag order?) Indeed, a rule that penalized parents for delegating their educational authority to schools or teachers might induce some parents personally to conduct their child's education even if they believed other educators could do a better job. Both children and freedom of speech are better served by applying the standard principal-agent model to indirect parental educative speech. ${ }^{284}$

${ }^{282}$ See Murphy $v$ Matheson, 742 F2d 564, 568 (10th Cir 1984) (Plaintiff smoke shops "of course have standing to assert that their personal commercial free speech rights have been infringed" by ban on advertisements of drug paraphernalia that "interfere[s] with their own advertising ... by display or by radio."); Washington Mercantile Association $v$ Williams, 733 F2d 687, 689 (9th Cir 1984) (Publishers of periodical have standing to challenge bar on advertisements of drug paraphernalia "on the ground that it unconstitutionally infringes some commercial speech rights.").

${ }_{283}$ See Levine $v$ United States District Court, 764 F2d 590 (9th Cir 1985).

${ }^{284}$ I do not claim that every message communicated by teachers or school officials to a child constitutes speech by that child's parents. But when parents intend to communicate particular values or knowledge to their child and choose teachers or schools based on their willingness to convey those messages, the messages constitute parental speech although they are delivered by an intermediary. See Randall P. Bezanson, Institutional Speech, 80 Iowa L Rev 735, 781 (1995) (When the source of a particular message is "an individual who intends by the speech that another has communicated to express his or her own ideas, the claim of freedom of speech-the individual liberty to speak freely-belongs to that individual."). The same conclusion should apply in the intermediate situations in which parents choose a school because they generally endorse its values and orientation. As Bezanson argues, the Supreme Court's decision in FEC $v$ Massachusetts Citizens for Life, Inc., 479 US 238 (1986) strongly suggests that when persons "know how their funds would be directed, at least in a general sense and in relation to fairly specific ... ends," their individual contributions to an association or organization (in $F E C$, a nonprofit corporation; here, a school) can "reasonably be understood as a conscious and intentional means of expressing their personal views." 80 Iowa $L$ Rev at 780. By contrast, parents 
Thus, state regulation that interferes with the speech of parentally chosen schools and teachers also interferes with the educative speech of the parents themselves. ${ }^{285}$ As we shall see, this conclusion enables us to evaluate most forms of educational regulation in terms of their impacts on parents. Moreover, parents' free speech rights encompass not only their speech through educational intermediaries, but also their decisions about whether, when, and through which such intermediaries they prefer to communicate with their children. Such rights are not the least bit novel. In general, a person's freedom of speech includes the right to select and employ other persons to speak on his or her behalf. For example, political candidates have a free speech right to speak through campaign workers, and public employees have a free speech right to present their views to government officials through their chosen representatives, as well as individually. ${ }^{286}$ The same principle gives parents a free speech right to decide who shall educate their child on their behalf. Of course this right is not absolute. Like parents' right to decide which messages their educational agents shall communicate, however, it is grounded in freedom of speech rather than in substantive due process or freedom of religion. ${ }^{287}$ As such, both

who choose a school on content-neutral grounds (for example, because the school is located near the child's home) may be insufficiently associated with the messages the school imparts to qualify as speakers. Even in this last category of cases, of course, private teachers and schools can invoke their own free speech rights against viewpoint-based state regulation. In light of the special importance of parental educational authority, however, private teachers' speech should perhaps receive less protection when the child's parents have not endorsed its content in even a general way.

${ }^{285}$ Under some circumstances, this proposition holds true even when parents choose a public school rather than a private one. It is certainly true, as the conventional view holds, that public education is a form of government speech. See, for example, Yudof, When Government Speaks at 213-14 (cited in note 19). But it is plainly fallacious to posit that because speech is government speech it cannot also be individual (here, parental) speech. Suppose, for instance, that parents sent their child to a local public school because it offered a revisionist history curriculum sharply critical of the federal government. Were Congress to ban criticism of the federal government in public schools, surely these parents (as well as public school officials) could complain that their free speech rights had been infringed. The fact that the parents have selected a school because they wish their child to hear the messages its curriculum offers-rather than the fact that the school happens to be "public"-is controlling.

${ }^{286}$ See Fraternal Order of Police $v$ Mayor and City Council, 916 F2d 919, 922 (4th Cir 1990) (collecting cases).

287 Because it affects the ability of parents, children, and private schools to associate for the promotion of values and ideas, state regulation of education also raises freedom of association issues under the First Amendment. In Runyon $v$ McCrary, for example, the Court assumed that freedom of association protects the rights of parents to choose, and children to attend, schools that advocate racial segregation, although the court held that the schools themselves could not discriminate. 427 US 160, 176 (1976). Moreover, because 
these rights represent significant shifts in the way we look at parental educational authority.

4. The impact of state regulation of education on parental educative speech.

Having established the broad scope of parental educative speech, we can now turn to an examination of how the most important types of state educational regulation interfere with it. Throughout the discussion that follows, I shall assume that each of the state interventions I consider is intended to promote some set of democratically chosen values that clashes in important ways with the values dissenting parents wish to teach their children. ${ }^{288}$ The inquiry focuses on the core cases in which the force of law backs values that some parents reject but that the majority wishes all children to learn.

a. Prohibitions on parental educative speech. Direct prohibition of certain parental messages is the simplest form of state interference with parental educative speech. A law that forbids parents to teach communism or racism to their children is, on its face, a total ban on parental speech propounding the disfavored viewpoint. ${ }^{289}$ On the analysis of indirect parental speech $I$ have proposed, a law forbidding schools (but not parents) to teach communism or racism differs only in that the ban is partial rather than total. ${ }^{290}$ In either case, it is presumptively unconstitu-

such regulation affects the relationships between parents and children, it implicates freedom of association in a second respect as well. See Board of Directors of Rotary International $v$ Rotary Club of Duarte, 481 US 537, 545 (1987) ("[T]he First Amendment protects those relationships, including family relationships, that presuppose deep attachments and commitments to the necessarily few other individuals with whom one shares not only a special community of thoughts, experiences, and beliefs but also distinctively personal aspects of one's life."). This Article does not explore how these freedom of association paradigms might apply to the various forms of state educational regulation, or how they interrelate with the paradigm of parental free speech.

${ }_{288}$ I have, in adopting this simplifying assumption, put aside many other issues that a comprehensive theory of parental free speech would need to address. For example, I do not address educational regulation that has the effect (but not the intent) of promoting some values at the expense of others, or that primarily deals with skills and knowledge rather than values.

280 A statute that banned parents from teaching these prohibited doctrines without mentioning schools or teachers would presumably be interpreted as a total ban that applied to parentally chosen schools as well.

${ }_{200}$ Such restrictions are rare, but not nonexistent. In addition to the English-only laws in Meyer, which I discuss in the text, see People v American Socialist Society, $202 \mathrm{AD} 640$, 195 NYS 801, 803 (1922) (upholding a law prohibiting the licensing of any private school that taught "that organized government shall be overthrown by force, violence or unlawful 
tional: viewpoint-based prohibitions on speech are rarely permissible, even if they arguably advance a compelling state interest. ${ }^{291}$

The English-only law at issue in Meyer should be viewed as a similar prohibition on parental educative speech. A law forbidding parents from speaking a foreign language to their children would blatantly violate the First Amendment. The ban on foreign-language instruction in Meyer, however, applied only to schools. ${ }^{292}$ Consequently, parents could still instruct their children themselves or hire teachers to provide individual instruction. Nonetheless, for many parents these alternatives would be impractical or unaffordable. The curtailment of parental educative speech is thus a major one.

Moreover, although the prohibition on its face seems to be based on content rather than viewpoint (because it applies to all modern foreign languages), even content-based restrictions on speech are normally justifiable only if narrowly tailored to advance a compelling state interest. The law in Meyer violated the First Amendment because a requirement that students learn English offered a more direct and less burdensome means of advancing the goal of universal fluency in English. ${ }^{293}$

b. Compulsory parental educative speech. The flip side of forbidding parental speech is compelling it. Consider a statute requiring all ten-year-olds to receive instruction in a controversial version of gender equality. This measure compels all dissenting parents to communicate to their children messages with which they disagree. Parents who home school are obliged to

means").

201 In Runyon, the Court rejected a freedom of association challenge to the constitutionality of a federal statute prohibiting private schools from engaging in racial discrimination in admissions. The Court "assumed that parents have a First Amendment right to send their children to educational institutions that promote the belief that racial segregation is desirable," but held that "the practice of excluding racial minorities from such institutions" was not "protected by the same principle." Runyon v McCrary, 427 US 160, 176 (1976). For criticism of the latter holding, see Mary-Michelle Upson Hirschoff, Comment, Runyon v McCrary and Regulation of Private Schools, 52 Ind L J 747 (1977).

$282 \quad 262$ US at 397.

293 A law requiring all children to receive instruction in English would also raise free speech issues as applied to children whose parents object to such instruction. It too involves content-based interference with parental educative speech, albeit in the form of compelled (rather than forbidden) communication. Although I cannot undertake a full First Amendment evaluation of an English-instruction law here, the state's interest in preserving a common civic language might be sufficiently compelling to justify a narrowly tailored version. 
conform their direct educative speech to the majority's commands. Parents who send their children to schools that would not otherwise teach this curriculum are, in much the same way, obliged to conform their indirect educative speech. In both cases, these obligations seem inconsistent with the principle for which Board of Education $v$ Barnette stands-namely, that free speech includes not only the right to say what one thinks true, but the right not to affirm what one thinks false. ${ }^{294}$

To be sure, restrictions of this kind do not prevent parents from informing the child of their disagreement with the state's values and providing counterbalancing instruction. But the playing field has tilted sharply and on the basis of viewpoint. The ability of parents in the majority to communicate their values to their children is enhanced by the state's endorsement of their values, while that of parents in the minority is substantially undermined because they, unlike majority parents, are required by law to expose their children to beliefs they think untrue. It comes as no surprise, therefore, that the speaker's extensive residual freedom of speech was not decisive in any of the cases in the Barnette line ${ }^{295}$ because in each of them the compelled expression of beliefs antithetical to the speaker's own entailed a serious, viewpoint-based disparity in treatment. As the Supreme Court unanimously reaffirmed last Term, "the choice of a speaker not to propound a particular point of view ... is presumed to lie beyond the government's power to control." ${ }^{\text {296 }}$ Curriculum regulation that mandates the teaching of a particular viewpoint is thus presumptively unconstitutional. ${ }^{297}$

294319 US 624, 642 (1943) (holding that schools cannot require children to salute and pledge allegiance to the flag).

${ }_{295}$ Outside school, the children in Barnette were free to repudiate the pledge and receive supplemental instruction in the values they thought inconsistent with it. In Wooley $v$ Maynard, the pacifist automobile owners were free to plaster stickers expressing their dissenting views all over their car, thereby counteracting the "Live Free or Die" message state law required their license plate to display, but the Court still found the law unconstitutional. See Wooley v Maynard, 430 US 705, 722 (1976) (Rehnquist dissenting). The newspaper in Miami Herald Publishing Co. $v$ Tornillo was free to publish an unlimited number of editorials criticizing political candidates, so long as it also published the replies state law required it to provide to those candidates free of charge, but, again, the Court found the law unconstitutional. See Miami Herald Publishing Co. v Tornillo, 418 US 241, 256 (1974).

296 Hurley $v$ Irish-American Gay, Lesbian and Bisexual Group, 115 S Ct 2338, 2348 (1995). As in the other cases in the Barnette line, the organizers of the Boston St. Patrick's Day Parade could have disavowed the implicit message of the homosexual and bisexual group they refused to allow to march in the parade. Yet the Supreme Court struck down Massachusetts's public accommodation law as applied to require the parade organizers to include the excluded group. Id at 2347.

${ }_{297}$ One objection to this analysis is that the First Amendment harm in cases like 
c. Compulsory public schooling. We come now to the type of regulation at issue in Pierce: compulsory public schooling legislation. I shall again assume (as was true in Pierce) that such a law is meant to foster values and beliefs the majority thinks every child should be taught. Its first effect is restrictive: during the days and hours when public school is in session, dissenting parents may not communicate their educational messages to their children, either directly or through the intermediaries of their choice. Parents remain free to teach what they like when their child is not in school, but there are only so many hours in the day. Six hours a day, five days a week, nine months a year, only the public school's values may be communicated to one's child. This de facto prohibition unquestionably constitutes a major curtailment of dissenting parental educative speech. There is, by contrast, no reduction whatsoever in the educative speech of parents whose values place them in the majority. On the contrary, their viewpoint receives the endorsement of a system of state-operated schools that now enjoys monopoly status and that screens out dissenting parental viewpoints from its curriculum.

This massive viewpoint-based restriction on parental educative speech should more than suffice to make out a First Amendment violation. Yet a value-driven compulsory public schooling law has a second major effect that is no less subversive of free speech: within the realm of public schooling, society by force of law substitutes the majority's educative speech for the educative speech that dissenting parents would otherwise transmit to their children. The state is thus simultaneously blocking and subverting parental educative speech on the basis of viewpoint. ${ }^{298}$ The

Barnette is limited to the personal affirmation of beliefs one rejects. Even if this objection were persuasive, it would apply neither to the claims of home schooling parents nor the claims of dissenting teachers. In fact the objection rests on a crabbed reading of Barnette that fails to explain cases such as Wooley and Tornillo, in which no personal affirmation was required. The Barnette principle is a broader one that reaches situations in which others are so likely to identify the speaker with the compelled expression that disavowal is necessary (whether or not effective). This identification is obvious in the case of home schooling: the child is likely to assume that the curriculum reflects the parent-teacher's views, and the parent is likely personally to read or review this curriculum with the child. A similar identification is present in the case of a parentally chosen school as well. Absent a disclaimer by their parents or the school, children will assume that their parents want them to receive whatever instruction the school provides.

${ }^{208}$ In light of the fact that a Pierce-type statute leaves dissenting parents no choice but to send their children to public school, it might be wrong to say that they are being forced to communicate or affirm beliefs with which they disagree. Arguably, under these circumstances dissenting parents are not sufficiently identified with the public school's speech to come within the Barnette line of cases. Since my analysis makes it unnecessary 
two effects are mutually reinforcing: the exclusion of dissenting parental speech from the schools truncates the time available for dissenting parents to educate their children; the public school's substitution of the majority's educational messages forces dissenting parents to spend much of their scarce remaining time counteracting what the school has done; and the result is that dissenting parents face an enormous handicap in the competition to pass on their values and beliefs to the next generation. This destructive double whammy makes Pierce an easy case in free speech terms.

\section{d. Compulsory schooling laws. Compulsory schooling} laws normally do not pose serious First Amendment problems, because both their likely motivations and their ordinary effects are much less troublesome than the other types of restrictions we have considered. These laws are unlikely to be motivated by a desire to impose viewpoint-based restrictions on parental educative speech. A legal requirement that parents provide their child with the basic education of their choice enables virtually all parents to comply with their legal obligations while simultaneously communicating with their child on terms consistent with the parents' values. In extreme cases, such a law may conceivably have a viewpoint-based effect: imagine parents who believe that numbers and counting are evil practices that their child should not learn. But parents who, absent legal obligation, would fail to teach their child mathematics because they are incompetent to do so, or because they don't perceive its importance, vastly outnumber parents who think basic mathematics is evil. The presumptive purpose of a law requiring compulsory education in basic mathematics is thus not to place a particular viewpoint at a disadvantage, but to impose an obligation on all parents regardless of viewpoint. Assuming, however, that the viewpoint-based effects of such a law, as applied to our hypothetical parents, require some form of compelling state interest analysis, it seems plain that the state still wins. For the parental view in question seems unreasonable even on an appropriately inclusive conception of what counts as reasonable: no established tradition condemns basic numeracy, the lack of that competence would severely handicap a child in virtually every way of life, and there is a clear consensus in favor of teaching children these skills that bridges a broad range of conceptions of the good life. 
As this analysis suggests, compulsory schooling laws will usually have little if any impact on parents' efforts to instill in their children their values or way of life. Virtually all parents want their children to receive at least a basic education. Even the Amish parents in Yoder had no objection to eight years of conventional classroom schooling, and their objection to high school was not that Amish children need only an eighth-grade education; it was that Amish teenagers need an Amish intermediate education. ${ }^{299}$ Mark Yudof thus has it backwards when he argues that "[c]ompulsory-attendance laws themselves are a more significant interference with parental autonomy than the Pierce law; for the decision that children must attend some school for eight or more years of their lives appears more consequential than a decision that they must attend public school. ${ }^{300}$ The relevant question should be which decision runs deeply counter to the values of dissenting parents, not which is more "consequential" in the abstract. In terms of value conflicts, it seems evident that a compulsory public education law like that struck down in Pierce would nowadays be vastly more divisive than a simple compulsory education law. ${ }^{301}$

e. Selective funding. Selective funding of public schools raises profound free speech problems. Once again, I shall assume that the majority's decision to withhold funding from all private schools is intended to promote the values taught in the public schools by inducing parents to choose public education for their children. ${ }^{302}$ So conceived, selective funding is intended to, and in fact does, discriminate between parental speakers on the basis of viewpoint. The educative speech of parents who share the majority's viewpoint is subsidized in the form of free public education. The educative speech of dissenting parents is not; they

299 Yoder, 406 US at 222.

${ }^{300}$ Yudof, When Government Speaks at 229 (cited in note 19).

${ }^{301}$ This conclusion would not apply if-as Yudof may be supposing-the compulsory education law is interpreted to forbid home schooling. A requirement of that kind might well be viewpoint based, and hence a more searching evaluation would be necessary.

${ }^{302}$ I recognize that this assumption will be descriptively controversial as applied to our existing systems of public education. But the fact that the rise of selectively funded public schools in the nineteenth century was explicitly linked to converting Catholic immigrants and other outsider groups away from their parents' beliefs shows, at the very least, that this assumption is not without historical foundation (and consequently, descriptive plausibility). A complete analysis of the actual purposes and effects of selective funding would require an equally full treatment of the public school system in this country, which I shall not venture to provide in this Article. 
must pay their own way, whether in the form of private school tuition or the labor of home schooling. The result is powerful, though indirect, governmental pressure on dissenting parents to conform their educative speech to the majority's preferred values. ${ }^{303}$

Selective funding can therefore be seen as a weaker version of compulsory public schooling. ${ }^{304}$ Parents may refuse to send their children to public schools, but the penalty for refusing is heavy, oftentimes unaffordable. The selective funding law is a major viewpoint-based license fee that dissenting parents must pay to engage in educative speech within the sphere of formal schooling. Outside that sphere, all parents may say what they like. But this residual freedom of speech no more saves selective funding than it does compulsory public education.

A more plausible distinction between selective funding and compulsory public schooling is that the former should not be seen as coercive. This distinction, however, fares poorly under the free speech case law, and rightly so. As Barnette illustrates, the fact that parents may-at considerable cost-use the Pierce exit option does not immunize state educational regulation from First Amendment scrutiny. The mandatory flag salute in Barnette was required by law only in the public schools. ${ }^{305}$ Yet the Supreme Court held that imposing this condition upon receiving a free education constituted the "coercive elimination of dissent." Because it creates a penalty for dissent indistinguishable from the one in Barnette, the same conclusion applies to selective funding in general. Consequently, at least when selective funding is intended to induce parents to conform their educative speech

${ }^{303}$ This pressure would be greatly reduced if public schools routinely excused children from studies to which their parents had serious value-based objections. Given my initial assumption that selective funding is meant to induce parents to accept the public school curriculum in toto, I shall also assume a corollary practice of denying such accommodations. Mozert certainly suggests that this assumption is a realistic one in many states and school districts.

304 In one respect, however, selective funding increases cognizable First Amendment harms. Parents who are induced by selective funding to send their children to public schools, despite harboring grave objections to the values their children will be taught, will more readily be assumed (by their children and others) to be associated with and endorsing the majority's values than parents who are compelled by law to do so. See note 297 .

${ }^{306}$ See Barnette, 319 US at 626. Indeed, in Minersuille School District $v$ Gobitis, the Jehovah's Witness parents brought suit after they had enrolled their children in private schools to escape the flag-salute requirement; they sought " $[t] 0$ be relieved of the financial burden" they bore as a result of being "denied a free public education." 310 US 586, 592 (1940), overruled by Barnette, 319 US at 642.

${ }^{306}$ Barnette, 319 US at 641. 
to the majority's values, it should be seen as presumptively unconstitutional. ${ }^{307}$

5. The "parental censorship" objection to the theory of parental educative speech.

An important objection to this theory of parental educative speech is that it would actually reduce freedom of speech by giving individual parents extensive authority to censor the educational messages government seeks to communicate to their children. If the majority decides that all children should hear certain value-laden messages as part of their formal education, while leaving dissenting parents free to express their disagreement at other times and places, it is the dissenters, not the state, who seek to restrict the range of viewpoints to which children are exposed. The robust exchange of ideas that free speech protects, the argument goes, should be seen as antithetical to any rule that gives $\mathrm{A}$ the right to prevent B's speech to $\mathrm{C}$.

The technical response to this argument is that the First Amendment limits state actors, not parents-and for good reason. For behind that technicality lies the vast difference in potency between the censoring and debate-skewing powers of the state, on the one hand, and of private individuals, on the other. A private landowner who dislikes Candidate A's message can refuse permission to enter his or her land to deliver it, while welcoming Candidate B with open arms. This private speech-excluding decision is one legitimate form of vigorous competition among ideas. But let the landowner be the state and the land be a public park, and the analysis is radically transformed: now we have viewpoint-based discrimination in access to a public forum-a

307 This formulation does not resolve the subtle and difficult question of how "intent" should be determined, for purposes of free speech analysis, in the case of a longstanding governmental practice such as selective educational funding. For example, should the very large magnitude of the burden created by selective funding give rise to a stronger inference of intent than in cases where selective funding involves subsidies that are more modest relative to the means of the affected speakers? Should the fact that public school officials refuse to accommodate the reasonable request of dissenting parents to excuse their child from objectionable aspects of the curriculum give rise to an inference that the officials are intentionally denying the child a free public education on viewpoint-based grounds? Conversely, should the fact that a school district makes reasonable efforts to accommodate dissenting families give rise to an inference that the continuing financial pressure on parents who select private schools is unintended? Depending on how these questions are answered, selective funding-as actually practiced in the United States-may involve "intentional" viewpoint-based discrimination routinely or (at the other end of the spectrum) only infrequently. 
straightforward infringement on free speech. Why the difference? There are many private landowners, some of whom are likely to approve of Candidate A's message and exclude Candidate B. The state, by contrast, owns all the public parks, and the uniform exclusion of Candidate A's message from these important public fora powerfully slants the debate in favor of Candidate $B$.

This analysis carries over to the context of parental educational authority. Child A's parents may exclude the government's educative speech, but Child B's parents may endorse it. Indeed, because the government's speech presumably tracks the majority's values, there will ordinarily be more B's than A's. The real threat is not to the government's speech: on the contrary, as I have shown, it is to the educative speech of dissenting parents. There is no merit, then, to the claim that a free speech theory of parental educational authority is ruled out because it would enable dissenting parents to exclude any governmental speech they think their children should not hear.

6. The "government speech" defense of viewpoint-based selective funding.

I turn finally to a more potent objection, albeit one that applies only to my analysis of selective funding. Selective funding of public education undeniably constitutes speech by the government. Therefore, the argument goes, the controlling First Amendment doctrine is "the principle that when the State is the speaker, it may make content-based choices." ${ }^{308}$ As the Court reiterated last term in Rosenberger $v$ Rectors and Visitors, this principle applies not only to the direct speech of government officials, but also "[w]hen the government appropriates public funds to promote a particular policy of its own." ${ }^{309}$ In either circumstance, the state is "entitled to say what it wishes" ${ }^{310}$ - that is, to prefer its viewpoint to others and to implement that preference with public funds and programs. In Rust $v$ Sullivan, for example, the Court held that the federal government may prohibit recipients of federal funds for family planning counseling from giving abortion-related advice. ${ }^{311}$ Consequently, whether we view public education simply as direct government speech, or as a program designed to advance particular educational policies, the practice 
of funding only public schools does not violate the First Amendment.

This argument certainly has some force in terms of Supreme Court precedent. Indeed, the view that selective educational funding-even if viewpoint based-is consistent with the First Amendment may currently command a comfortable majority of the Justices. But predictions of this kind should not be decisive against the theory I have proposed, which seeks to persuade the Court (and commentators) that powerful First Amendment arguments against viewpoint-based selective funding have gone unremarked. ${ }^{312}$ In fact, many of the materials for this rethinking are already present in the Court's opinions.

As we shall see, Rust and Rosenberger do not stand for the proposition that government speech is completely immune from First Amendment scrutiny. Such a rule would be bizarre. The power to fund speech selectively from general tax revenues plainly has the potential to function as a regulatory technique to deter persons from expressing disfavored ideas. That the First Amendment does not explicitly restrict government speech is irrelevant. The First Amendment does not explicitly restrict government tax levies either, yet content-based taxes are unconstitutional because they threaten the free competition of ideas quite as much as direct restrictions on what may be said. ${ }^{313}$ The parallel proposition for government speech is simply this: at least when government uses its power to fund speech for the purpose of impeding the private expression of disfavored ideas and in ways that are likely to have a major inhibiting effect, this behavior should be characterized as viewpoint-based regulation rather than permissible government speech. ${ }^{314}$

312 This is not to suggest that stare decisis has no role to play in constitutional adjudication. Usually, however, it does not pretermit reexamination of an important constitutional question, regardless of how much it might influence the final outcome. And in any event, there is no Supreme Court precedent upholding selective funding of compulsory education against First Amendment or other constitutional attacks, though there is dictum to that effect in Harris $v$ McRae, 448 US 297, 318 (1980) ("It cannot be that because government may not prohibit the use of contraceptives, or prevent parents from sending their child to a private school, government, therefore, has an affirmative constitutional obligation to ensure that all persons have the financial resources to obtain contraceptives or send their children to private schools."). See also the rather dismissive treatment of the issue in Tribe, American Constitutional Law at 782 (cited in note 220) ("Whatever one thinks of the validity of educational voucher plans, one surely cannot argue that the Constitution compels government to institute them.").

${ }^{313}$ See Arkansas Writers' Project, Inc. $v$ Ragland, 481 US 221, 230 (1987) (“[O]fficial scrutiny of the content of publications as the basis for taxation is entirely incompatible with the First Amendment's guarantee of freedom of the press.").

${ }^{314}$ Cass Sunstein reaches a similar conclusion (though not about selective funding of 
Although Rust and Rosenberger do not explicitly articulate this proposition, they do support it in several ways. In Rust, the Court emphasized that the prohibition on advice pertaining to abortion was not leveraged: that is, it applied only to the federally funded programs, not to separate activities of persons or organizations affiliated with those programs. ${ }^{315}$ At first glance, this might suggest that the government may condition free education on enrollment in a public school that teaches the government's preferred values, but may not impose the additional condition that parents abstain from communicating their values to their children outside school. But as Michael McConnell argues, selective funding of public education already is leveraged: families that forgo public schooling forfeit the entire public-school subsidy for education, even if the private school they choose in large part duplicates the public school's curriculum and values. ${ }^{316}$ "It is as if those who got an abortion were thereby excluded from Medicaid" (rather than deprived only of the funding available for childbirth). ${ }^{317}$

Even if selective educational funding were seen as unleveraged, the Court in Rust also stressed that it did "not ... suggest that funding by the Government, even when coupled with the freedom of the fund recipients to speak outside the scope of the Government-funded project, is invariably sufficient to justify Government control over the content of expression."318 Without spelling out the limits on unleveraged selective funding, the Court intimated that places and relationships traditionally considered as "sphere[s] of free expression" would receive substantial protection. $^{319}$ If, as the Court suggested, selective funding may

public schools) in his illuminating discussion of selective funding of speech. He argues that serious First Amendment objections are present when government discriminates against people in funding "based on their point of view" because in such circumstances "both the purpose and the effects of governmental action are objectionable." Sunstein, Partial Constitution at 310 (cited in note 255). Sunstein suggests that it will often be difficult-conceptually as well as practically-to determine whether the government's refusal to fund speech rests on point of view or instead on some permissible ground. Id at 311. His proposed solution is to invalidate selective funding only when it involves "straightforward ... viewpoint discrimination," that is, when it is "conspicuously partisan." Id at 312. Although I suspect a less deferential test might still be workable, the core point of Sunstein's analysis-that selective funding is illegitimate when used as a technique for partisan discrimination against disfavored viewpoints-strongly supports the formulation in text.

${ }^{315}$ See Rust, 500 US at 198-99.

${ }^{318}$ See McConnell, 104 Harv L Rev at 1017-18 (cited in note 18).

317 Id at 1017.

318 Rust, 500 US at 199.

319 Id at 200 (discussing universities). 
be problematic when it significantly disrupts communication within the physician-patient relationship, ${ }^{320}$ then selective funding that significantly disrupts communication within the parentchild relationship ought to be suspect too.

In one sense, Rosenberger demonstrates that this portion of the Rust opinion was not an empty gesture. The Rosenberger Court held that by selectively funding the printing costs of only student newspapers that do not promote or manifest religious belief, a state university unconstitutionally discriminated against religious viewpoints. ${ }^{321}$ As in $R u s t$, the selective funding was unleveraged: a religious student group could have engaged in religious speech and expression while receiving funding for its student newspaper so long as the newspaper was not primarily religious. Yet the Court concluded that by subsidizing only nonreligious newspapers the university was "silenc[ing] the expression of selected viewpoints."

To reach this result, however, the Court had to distinguish Rust and the other cases upholding viewpoint-based funding of speech. The Rosenberger Court primarily relied on the distinction between viewpoint-based government speech and viewpoint-based funding of private speech. "[V]iewpoint-based restrictions," the Court said, cease to be proper:

[W] hen the University does not itself speak or subsidize transmittal of a message it favors but instead expends funds to encourage a diversity of views from private speakers. A holding that the University may not discriminate based on the viewpoint of private persons whose speech it facilitates does not restrict the University's own speech, which is controlled by different principles. ${ }^{323}$

On its face, this distinction suggests that viewpoint-based funding of educational vouchers would violate the First Amendment, but viewpoint-based funding of public schools does not. Fortunately, however, that particular conclusion is far from inevitable. If the Court were persuaded by McConnell's powerful argument that selective educational funding is a forfeiture or

${ }^{320}$ Id. The Court, however, thought that the regulations at issue in Rust placed no significant burden on the physician-patient relationship because the clients of the federally funded Title X programs used those programs for the limited purpose of family planning. Id.

${ }_{321}$ Rosenberger, $115 \mathrm{~S} \mathrm{Ct}$ at 2517-19.

322 Id at 2519.

323 Id. 
penalty-that is to say, is leveraged in a way not true of the subsidies in Rust and Rosenberger-its precedents would point strongly toward a finding of unconstitutionality. ${ }^{324}$ If, on the other hand, the Court treated selective educational funding as unleveraged, the practice might still violate the First Amendment. Rosenberger does not suggest that there are no First Amendment limits on viewpoint-based government speech, only that those limits are much less restrictive than the virtually per se prohibition against viewpoint-based regulation of speech. In particular, Rosenberger's observation that "when the government appropriates public funds to promote a particular policy of its own it is entitled to say what it wishes ${ }^{1325}$ plainly rests on the assumption that the "particular policy" is one the Constitution permits the government to choose. This assumption is not satisfied when the government selectively funds speech for the purpose of deterring or inhibiting the expression of selected viewpoints. As the Court has repeatedly said, government may not "discriminate invidiously in its subsidies in such a way as to 'ai[m] at the suppression of dangerous ideas ....'”326 Whatever its merit, Rosenberger's distinction between government speech and government funding of private speech does not purport to trump that settled law. Rosenberger holds that government violates the First Amendment by engaging in viewpoint-based funding of university student newspapers that "cast[s] disapproval on particular viewpoints of its students" and thereby "risks the suppression of free speech and creative inquiry in one of the vital centers for the nation's intellectual life ...." ${ }^{327}$ Therefore, even though selective funding of public schools falls on the government speech side of the line, the Court should nevertheless be willing to find the practice unconstitutional if the selective funding of this government speech was intended to "suppress ... free speech" by "cast[ing] disapproval on particular viewpoints."

${ }^{324}$ See FCC $v$ League of Women Voters, 468 US 364, 385-86 (1984) (invalidating federal law barring all editorializing by noncommercial stations that receive federal grants); Regan $v$ Taxation with Representation, 461 US 540, 549-51 (1983) (upholding federal prohibition on the use of tax-deductible contributions to support the lobbying activities of tax-exempt charitable organizations because the organizations remained free to use deductible contributions to support nonlobbying activities).

${ }_{325} 115 \mathrm{~S}$ Ct at 2519.

${ }^{326}$ Id (alteration in original). See also Rust, 500 US at 194 (arguing that the regulation at issue there was 'not a case of the Government 'suppressing a dangerous idea,' but of a prohibition on a project grantee or its employees from engaging in activities outside of the project's scope").

${ }_{327}$ Rosenberger, $115 \mathrm{~S} \mathrm{Ct}$ at 2520. 
This preliminary sketch of a free speech theory of parental educational rights leaves many questions unanswered. Most importantly, I have made no attempt to evaluate the entire range of education-related ends in which states might claim to have a compelling interest, ${ }^{328}$ or the other justifications they might offer for practices such as selective funding. ${ }^{329} \mathrm{~A}$ full treatment of these issues would require a much closer look at the history, structure, and content of public education, and of state regulation of private education. I have tried to establish five basic propositions: first, that parents transmit values, beliefs, and skills to their children primarily by means of parental educative speech; second, that this category of speech is entitled to a high degree of First Amendment protection; third, that parental educative speech includes both parents' direct communication with their child and the speech of parentally chosen educational agents such as schools and teachers; fourth, that direct restrictions on parental speech, mandatory curriculum regulation, compulsory public schooling, and selective funding all involve large-scale coercive

${ }^{328}$ See, for example, McConnell, 104 Harv L Rev at 1047 (cited in note 18) (suggesting that selective educational funding may be justifiable on the grounds that public schools are generally more diverse than private schools, and that "this diversity is an important aspect of training for citizenship in a pluralistic United States"); Sunstein, Partial Constitution at 308 (cited in note 255) (States have "strong and legitimate reasons to favor public over private education in order (for example) to foster the development of an integrated national (or state) polity, to promote citizenship, and to break down barriers of race, religion and class."); Liebman, 101 Yale $\mathrm{L} J$ at 293-313 (cited in note 155) (arguing that selective funding can be justified as a sort of conscription system, in which the educational efforts of sophisticated parents can be made to benefit all children, not only their own, by giving them a stake in the success of the common schools). I am skeptical that any of these reasons provides either a legitimate justification for selective funding or an accurate account of why we actually engage in selective funding, but shall leave these important issues for another day. It seems clear, however, that states may not override value-laden parental educational choices on the ground that the majority prefers different values unless the parents' values are demonstrably harmful to children. Consequently, the justifications for selective funding invoked by many contemporary liberal theorists (for example, Gutmann and Crittenden), resting as they do on contestable conceptions of the good life and good citizenship, do not suffice.

322 For example, Sunstein argues that public funding of parentally chosen private education would largely go to fund religious schools, and that this would raise Establishment Clause problems of sufficient magnitude to justify selective funding. Sunstein, Partial Constitution at 307 (cited in note 255). In my view, this argument rests on an interpretation of the Establishment Clause that needlessly clashes with what Sunstein agrees is "the prohibition on discrimination based on point of view [that] lies at the heart of the First Amendment," id at 310, and, supposing that conflict to exist, unpersuasively resolves it in favor of the provision that is less central to the plan of the Constitution as a whole. See McConnell, 1991 U Chi Legal F at 143-49 (cited in note 33) (arguing that school-choice plans that reimburse parents for private school tuition do not violate the Establishment Clause under existing Supreme Court case law). 
interference with parental educative speech; and, fifth, that where any of these types of state educational regulation is enacted or implemented with the intent of promoting the adoption by all children of the majority's values, it constitutes unconstitutional viewpoint-based infringement of dissenting parents' educative speech. Taken together, these propositions warrant the surprising conclusion that First Amendment freedom of speech may be the best protection parents have against coercive state interference with their educational authority.

\section{CONCLUSION}

Notwithstanding the narrow character of its free exercise holding in favor of the Amish, the Yoder Court asserted more generally that the "primary role of the parents in the upbringing of their children is now established beyond debate as an enduring American tradition." 330 In constitutional terms, however, a baseline predicated on tradition is vulnerable to the objection that the citizens whose public laws and private conduct have over time given rise to a tradition should be free reasonably to revise that tradition through ordinary democratic means. The Yoder Court implicitly recognized the force of this objection when it described the general parental educational authority protected by Pierce, outside the context of religious upbringing, as an "interest" rather than a right. ${ }^{331}$ Contemporary political theory has tended to follow a similar course, treating parental educational interests as secondary to broad conceptions of the liberal state's interest in preparing children for public life and citizenship through formal schooling.

This Article has taken a different stand: the tradition of parental educational authority should be respected and enlarged, not subordinated to contestable norms of democratic education. This tradition is rooted in liberalism's commitment to tolerating competing reasonable conceptions of the good, and especially in its commitment to promoting the human flourishing of parents and children, both of which depend on parents' ability to nurture and educate their children by their own best lights. Provided their educational choices are reasonable (that is, do not violate the core notions of the human good and of social responsibility on which there is liberal consensus), individual parents should be 
free to pass on their values to their children and to reject state efforts to try to inculcate contrary values through mandatory public schooling, curriculum regulation, selective funding, or other coercive means. Arguments from parental incentives and parental ideals furnish a powerful theoretical basis for recognizing broad parental educational authority as a matter of substantive due process. But the best constitutional locus for implementing this theory of parental educational rights may be the First Amendment's guarantee of free speech and expression. Rightly interpreted, the First Amendment protects parental educative speech against viewpoint-based and content-based state regulation; and the category of parental educative speech should be understood to include both direct parental communication in the home and indirect parental communication, through parents' agents, in the schools that parents choose. 